ESCOLA POLITÉCNICA DA UNIVERSIDADE DE SÃO PAULO DEPARTAMENTO DE SISTEMAS ELETRÔNICOS

\title{
Melhoria de Processos pelo Levantamento de Indicadores Ambientais via Software
}

Emanuel Fernandes de Queiroz

São Paulo

2007 


\title{
EMANUEL FERNANDES DE QUEIROZ \\ Tecnólogo em Materiais, Processos e Componentes Eletrônicos
}

FATEC-SP - 2003

\section{Melhoria de Processos pelo Levantamento de Indicadores Ambientais via Software}

\author{
Dissertação apresentada à \\ Escola Politécnica da \\ Universidade de São Paulo \\ para obtenção do título de \\ Mestre em Engenharia.
}

Área de Concentração: Microeletrônica

Orientadora:

Prof ${ }^{-}$Dr ${ }^{a}$ Maria Lúcia Pereira da Silva

São Paulo

2007 


Queiroz, Emanuel Fernandes de
Melhoria de Processos pelo Levantamento de Indicadores Ambientais via
Softwares. São Paulo, 2006.
Dissertação (Mestrado) - Escola Politécnica da Universidade de São Paulo.
Departamento de Engenharia de Sistemas Eletrônicos.
1. Sustentabilidade 2. Ecologia Industrial 3.Ecossistemas Industriais 4.Softwares
de Gestão
I. Universidade de São Paulo. Escola Politécnica. Departamento de Engenharia
Eletrônica.


Dedico este trabalho a todos que se sensibilizarem com estas causas. A natureza é nossa herança para a eternidade, o que plantamos hoje será colhido por nossos sucessores. 


\section{AGRADECIMENTOS}

À Deus por colocar-me diante de todas as pessoas que tornaram este trabalho possível.

À CNPQ pelo apoio financeiro.

À Braxis IT Services pelo uso do software.

Ao Grupo de Tecnologias Limpas da USP, pelo apoio e incentivo. Rodrigo Amorim, Roberto Lima, Leonardo Hernandez, Fábio Pepe, Lílian Marques, Leandro Colevati, Janaína Gameiro, Antônio e Alexsander Tressino.

À minha dedicada orientadora, Maria Lúcia Pereira de Silva, pela confiança e instrução.

Aos amigos e companheiros Maurício Cancian, Alexandre Oliveira, Ana Mondoni, Fábio Valle, Daniela Mello, Antônio Vaz Junior, Érica Uyeda e Eduardo Miranda, pela compreensão e cooperação.

À toda minha família que sustentou este sonho.

À Gabriela Jundi pela inspiração. 


\section{ABSTRACT}

Nowadays, paradigm changes are needed and one of the most urgent changes required is to assure sustainability on human entrepreneurships. Therefore, entrepreneurship management will be modified and Industrial Ecology concept allied to software applications can be very useful.

The aim of this work was development of suitable methodology for Industrial Ecology concept implementation using software. Brazilian industries on the electronic sector were evaluated in order to define sustainability indicators and also to propose processes improvement using industrial ecosystems.

Preliminary evaluations of the electronic sector shows, due to the high value of the products, several possibilities for cost reduction and environmental and social improvement as well. The opportunities can be implemented with non-product exchanges inside the plants or among different plants, i.e. by industrial ecosystem formation. However, as industrial ecosystems require intense exchange among participants distance between plants is a high constraint and can associates a significant environemental impact, mainly due to carbon emission.

Reactants production for Microeletronics was formerly evaluated on QITS (Quartz Industrial Trade System) program. The program suggested the use of sugarcane biomass and quartz for silicon production. However, due to the high distances between these two products, carbon emission inhibits the ecosystem. Moreover, other products are also acquired and discarded in open circles.

Microelectronics can reuse water in partnership with the galvanic industries but not other products, such as acid and basic aqueous solution, mainly on metallurgic processes.

Print circuit board and surface mounting technology several non-products are already recycled, nonetheless the best economical practice would be a direct change, i. e., no recyclers involved. Aqueous solutions are hardly recycled due to distance between sites. Equipment recycling is a huge problem due to the legal concerns on disassembly 
For micro and small industries simple software, such as database, allows Industrial Ecology implementation with very low cost. These databases also favor obtaining sustainability indicators required for several stakeholders, such as stockers. 


\section{RESUMO}

Para o mundo atual é necessária a mudança de paradigmas e entre as mudanças mais prementes encontra-se a necessidade de garantir a sustentabilidade dos empreendimentos humanos. Assim, a gestão empresarial tende a mudar e, para adequarse a essa nova forma de gestão, o conceito de Ecologia Industrial e o uso de softwares de controle podem ser de grande valia.

O presente trabalho teve como objetivo desenvolver metodologia do uso desses softwares na aplicação do conceito de Ecologia Industrial em empresas da área de eletroeletrônicos, preferencialmente ligadas à área de microeletrônica, para definir indicadores de sustentabilidade adequados ao sistema e indicar possíveis melhorias de processo pela formação de ecossistemas industriais.

O setor eletroeletrônico foi avaliado preliminarmente e apresentou, devido ao alto valor agregado de seus produtos, várias oportunidades de redução de custos, de melhoria ambiental e social na cadeia produtiva devido à reutilização de co-produtos gerados internamente ou por outras empresas, sugerindo um esforço para aumentar a formação de ecossistemas industriais neste setor. Como a formação de ecossistemas industriais é muito dependente da troca, é relevante o fato dos estudos de caso mostrarem a importância das distâncias e, deste modo, entre os prováveis impactos significativos, a emissão de carbono precisa ser fortemente considerada.

Para a área de insumos para a microeletrônica, avaliada preliminarmente no programa QITS (Quartz Industrial Trade System), a possibilidade do uso de lascas de silício e de bagaço de cana é dificultada pelas distâncias entre os produtos e respectiva emissão de carbono decorrente do translado. Outros insumos são normalmente adquiridos e descartados em ciclos ainda mais abertos.

$\mathrm{Na}$ área de microeletrônica, ciclos de reuso de água com galvânicas existem, mas não de outros produtos, como soluções aquosas ácidas ou alcalinas, que poderiam ser recicladas em metalúrgicas, onde o grau de pureza exigido é menor.

$\mathrm{Na}$ área de circuito impresso e de montagem em superfície vários co-produtos já são reciclados, porém, uma troca entre produtores, não envolvendo recicladoras, proporcionaria um ganho econômico maior. Soluções aquosas similares às utilizadas em microeletrônica também poderiam ser utilizadas, porém, novamente as distâncias são as principais variáveis a dificultar tal processo.

A reciclagem de equipamentos completos esbarra em várias dificuldades, entre elas os aspectos legais.

Para as micros e pequenas empresas o desenvolvimento de banco de dados permite a implantação da Ecologia Industrial sem altos custos associados. Estes bancos de dados 
também favorecem a obtenção de indicadores requisitados por outros atores ambientais, tal como bolsa de valores. 


\section{ÍNDICE}

\section{RESUMO}

\section{ABSTRACT}

1.1 Atores Ambientais (Stakeholders) E Indicadores De Sustentabilidade.

1.1.1 Atores Ambientais

1.1.2 Indicadores De Sustentabilidade

1.2 Ecologia Industrial

1.2.1 Ecologia Industrial, Prevenção De Poluição E Produção Limpa

1.2.1.1 Considerações Sobre As Posições Dos Defensores Da Produção

Mais Limpa E Da Ecologia Industrial.

1.2.2 Ferramentas Da Ecologia Industrial E Da Produção Limpa....................................34

1.2.3 Ecossistemas Industriais E Avaliação Do Ciclo De Vida..........................................37

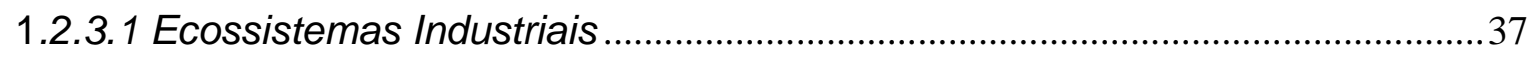

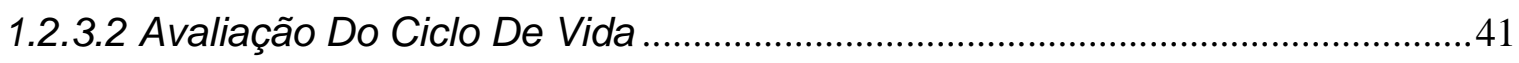

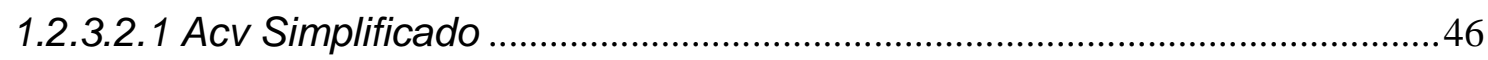

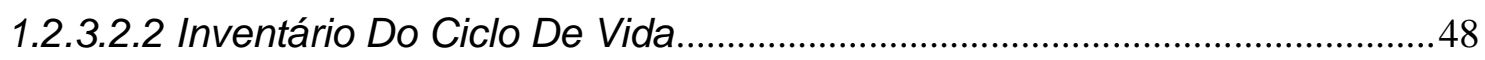

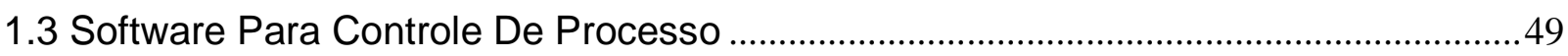

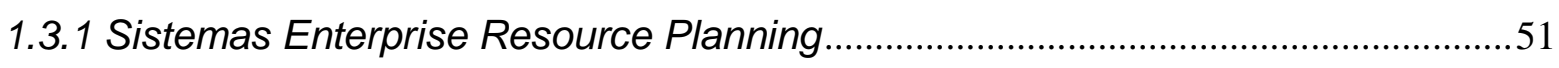

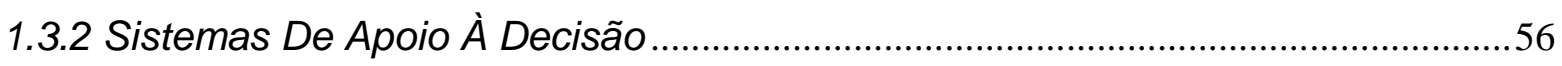

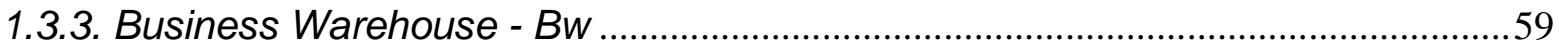

1.3.4 Interligação Entre Erp E Ecologia Industrial ........................................................60

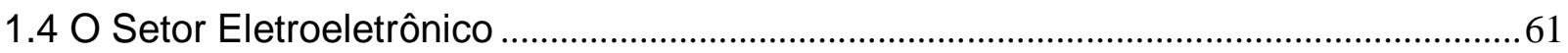

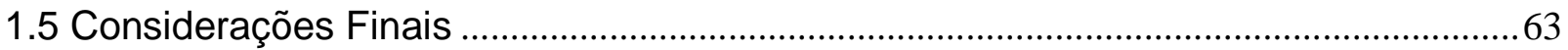

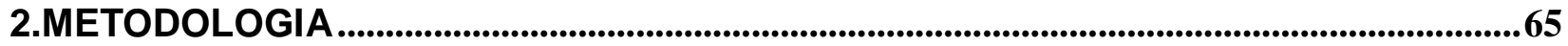

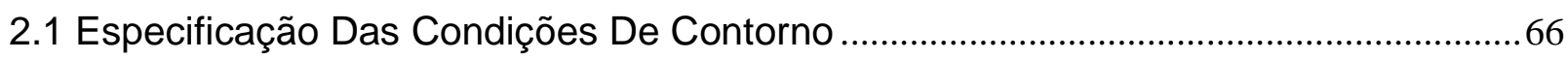

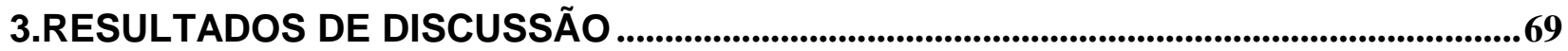


3.1 Composição Do Setor Eletroeletrônico No País .69

3.2 Premissas De Ecologia Industrial, Ferramentas E Indicadores Ambientais.................72

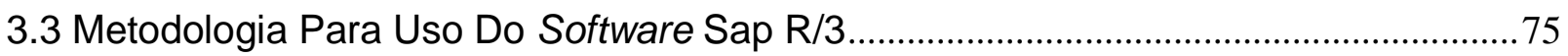

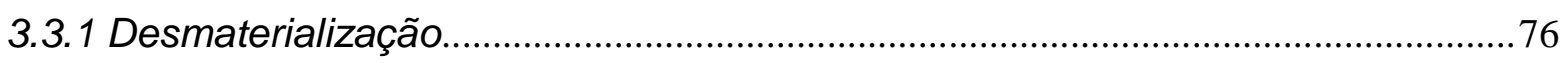

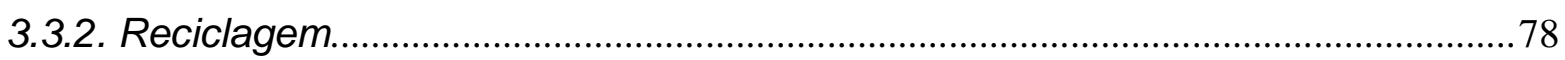

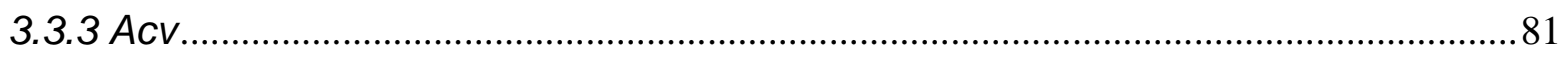

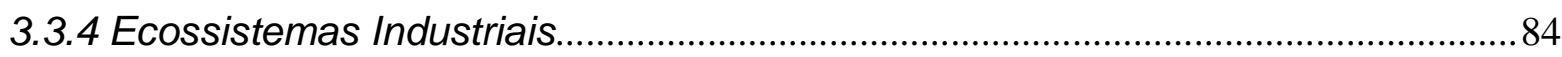

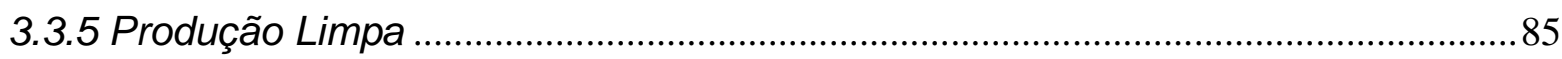

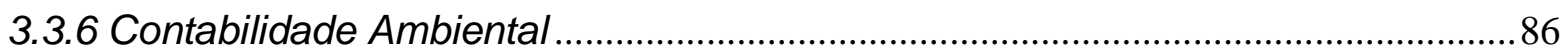

3.3.7 Normas Ambientais, Econômicas E Sociais............................................................87

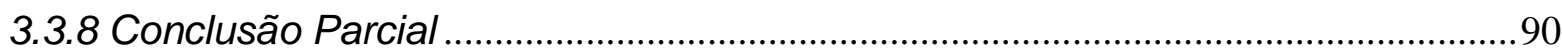

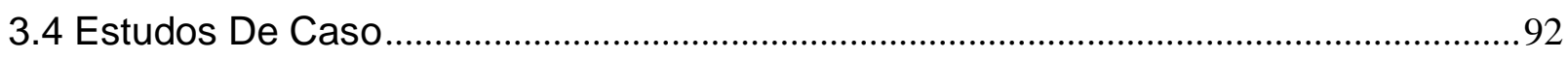

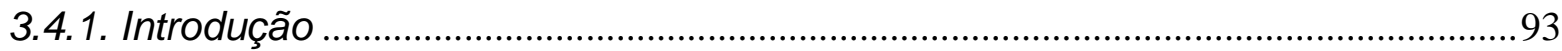

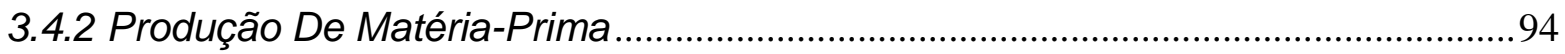

3.4.2.1. A Produção De Silício ....................................................................................94

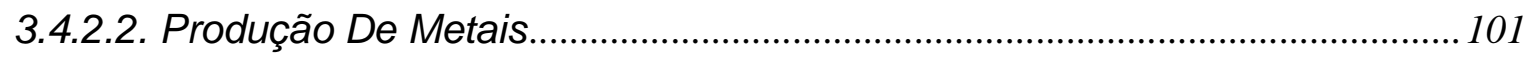

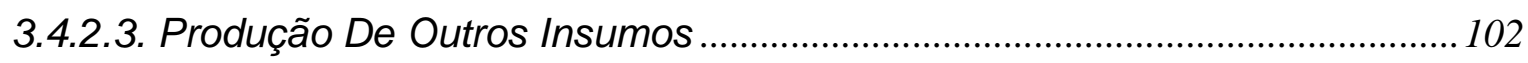

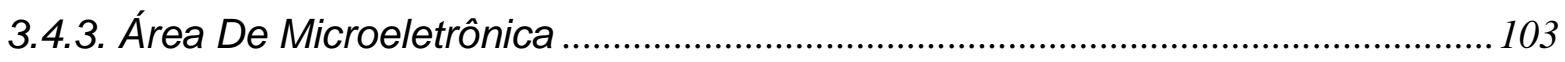

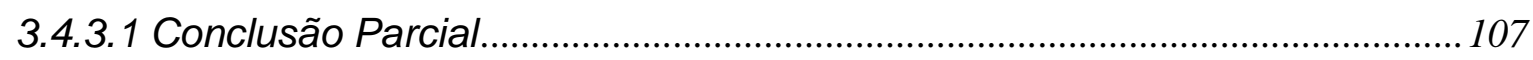

3.4.4 A Área De Circuito Impresso E Montagem Em Superfície....................................108

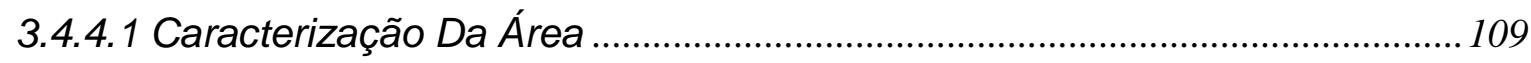

3.4.4.2 Avaliação Da Área Com O Uso De Software................................................112

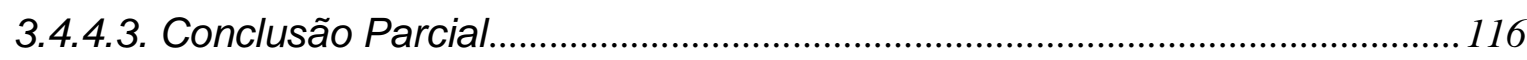

3.4.5 Montagem E Descarte De Equipamentos............................................................. 116

3.4.5.1 Reciclagem De Um Rádio Relógio .................................................................119

3.4.5.2 Reciclagem De Computadores E Celulares..................................................... 124

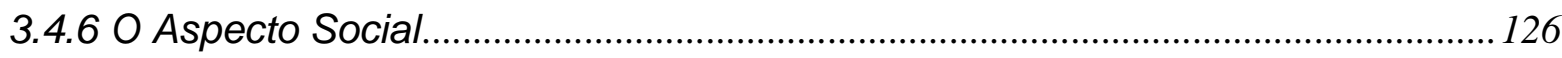

3.4.7 O Aspecto Econômico........................................................................................ 131

3.5 Propostas Para As Pequenas E Médias Empresas .....................................................134

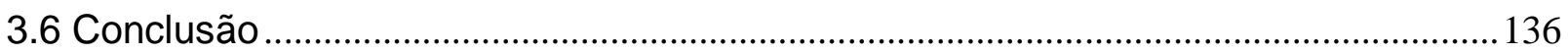

4.CONCLUSÃO E TRABALHOS FUTUROS .....................................................................138 


\section{ANEXOS}

\section{LISTA DE TABELAS}

Tabela 1.1 público a ser atingido pela comunicação ambiental e as principais dúvidas desse público, de acordo com o manual da UNEP.

Tabela 1.2 Matriz da ACV

Tabela 1.3 Questionário para AHP papel kraft e polietileno

Tabela 1.4 - Dados requeridos para o inventário do ciclo de vida

Tabela 1.5 - Dados relacionados com as estruturas organizacionais 24

Tabela 3.1 Distribuição do ramo de negócio da industria de eletrônicos no Brasil, segundo Abinee 38

Tabela 3.2 Relação entre Ecologia Industrial os indicadores de sustentabilidade descritos no Anexo 1.

41

Tabela 3.3 Principais demandas para implantação da Ecologia Industrial e possíveis conexões com o SAP R/3

42

Tabela 3.4 Dados do sistema de ERP a serem usados no LCI

49

Tabela 3.5 Resumo da correlação entre indicadores de sustentabilidade e as atendimento pelas funcionalidades do software. 
Tabela 3.6 possíveis co-produtos e/ou resíduos da produção de silício grau metalúrgico, de acordo com pesquisas realizadas no projeto QITS

68

Tabela 3.7 Alternativas propostas pelo projeto QITS para diminuir a emissão na produção 69

Tabela 3.8 Possíveis simbioses observadas.

71

Tabela 3.9: Caracterização dos tipos de água em relação aos fatores econômico, ambiental e de consumo

76

Tabela 3.10 principais resíduos, determinados por Gameiro (2002), e neste trabalho denominado por coprodutos, e sugestões de possíveis utilizações

77

Tabela 3.11. Principais resíduos e quantidades produzidas pela área de circuito impresso na Turquia

79

Tabela 3.12 Principais resíduos de acordo com 20\% dos associados da ABRACI 81

Tabela 3.13 estimativa do valor médio econômico dos co-produtos gerados por fabricantes de circuitos impressos

82

Tabela 3.14 Possíveis simbioses observadas através do uso de software.

90

Tabela 3.15 Percentual de co-produtos presentes em componentes eletroeletrônicos 91

Tabela 3.16 Percentual de reaproveitamento médio de co-produtos presentes em componentes eletroeletrônicos.

92

Tabela 3.17 Massa reciclada de componentes em uma tonelada de computadores 
Tabela 3.18 Questões para a aquisição de Dados

95

Tabela 3.19 Comparativo entre o SAP e o SQL (MysqlFont $\left.{ }^{\circledR}\right)$ para cadastro de dados relevantes para o balanço social

96

Tabela 3.20: Resumo da situação da empresa de telecomunicações antes e depois da consolidação de dados

99 


\section{i.INTRODUÇÃO}

Os graves problemas do mundo atual levaram a bem conhecida reunião de 1992, no Rio de Janeiro/Brasil, onde a Agenda 21 foi concebida (__,Agenda 21, 1992). Este documento traz em seu âmago o conceito de desenvolvimento sustentável e uma série de recomendações para que tal desenvolvimento seja obtido.

O conceito de desenvolvimento sustentável decorre de um relatório encomendado pela ONU (Organização das Nações Unidas) e denominado "Nosso Futuro Comum” de 1987. Este relatório considera o Desenvolvimento Sustentável como "o atendimento das necessidades da geração presente sem comprometer a capacidade de as gerações futuras atenderem também às suas" (World Commission on Environment and Development,1987). A aplicação deste conceito aos processos humanos corresponde à obtenção da sustentabilidade em nossas atividades. Sustentabilidade foi definida por Poudel (2002), como "a eficácia na forma de gestão que está sendo aplicada para obtenção de objetivos definidos... Portanto, é preciso definir corretamente os critérios para avaliar os objetivos, as metas e os atores envolvidos na questão... Vários métodos foram propostos por distintos autores para determinar critérios e indicadores e resultaram em ferramentas significativas de avaliação..."

Indicadores de sustentabilidade que atendam ao conceito de desenvolvimento sustentável devem considerar o tripé, ou um "banco", formado pelas necessidades ecológicas, econômicas e ambientais (POUDEL, 2002). Young aponta que, muito embora o ambiente seja o suporte de toda a vida, a humanidade criou a sociedade (tripé social) e definiu como esta deve funcionar (tripé econômico) e sugere que há uma base nesse tripé - daí a formação de um banco - e que este estabelece o processo de governança, que deve garantir a estabilidade do processo ao longo do tempo. Assim, índices que descrevam as três partes do tripé devem ser obtidos e Young propôs um framework, especificamente para a questão de mudanças climáticas, que dá igual valor a cada uma dessas partes. Muitos autores propuseram diferentes indicadores e/ou índices para as três componentes do tripé da sustentabilidade e, do mesmo modo, a ONU listou vários atores, normalmente citados como partes interessadas (stakeholders), a serem abordados quando da comunicação dos avanços conseguidos em direção ao desenvolvimento sustentável 
(UNEP, 1992). A preocupação com a aplicação do conceito de desenvolvimento sustentável ao setor produtivo também gerou novas definições, tais como Produção Mais Limpa e Limpa e Ecologia Industrial. A Produção Mais Limpa foi definida pela UNEP (United Nations Environmental Program) como "aplicação contínua de uma estratégia integrada de prevenção ambiental a processos, produtos e serviços, para aumentar a eficiência de produção e reduzir os riscos para o ser humano e o ambiente" (GIANNETTI, 2006). Por outro lado, a Ecologia Industrial faz uma analogia entre os sistemas industriais e os ecossistemas e considera que "todos os resíduos/materiais devem ser continuamente reciclados dentro do sistema e somente energia solar ilimitada seria utilizada de forma dissipativa.... A Ecologia industrial resgata a idéia de que a antroposfera é parte da biosfera e que somente pode existir em equilíbrio com as outras partes do sistema, a atmosfera, a hidrosfera e a litosfera ... O objetivo da Ecologia Industrial é formar uma rede de processos industriais mais elegante e com menos desperdício" (GIANNETTI, 2006). Assim, enquanto o foco da Produção Limpa é para a minimização na fonte da formação do resíduo a Ecologia Industrial preocupa-se com o fluxo de materiais, o metabolismo industrial, e sua interação como o meio ambiente. Outro aspecto relevante é que a Ecologia Industrial pressupõe a formação de ecossistemas industriais - empresas funcionando sinergeticamente em intensa troca de matéria e energia, conceito este que será abordado nesse trabalho.

Tanto a Produção Limpa quanto a Ecologia Industrial pressupõem a definição e o uso de uma série de ferramentas, o que também permite a definição de vários indicadores de sustentabilidade, na concepção comentada anteriormente. A ferramenta mais comumente associada à Ecologia Industrial é a Avaliação do ciclo de vida (ACV). A ACV permite que toda a matéria e energia envolvida na produção de um bem sejam computadas. Assim, dois produtos similares podem ser comparados para determinar qual apresenta menor impacto ambiental (HUNKELER, 2005). Normalmente ACV de um produto é feita pelo uso de softwares especializados, mas já se nota uma tendência do uso para o mesmo fim de softwares de controle (HENDRICKSON, 2001), como o SAP (Enterprise Resource Planning - SAP), que são bastante comuns em grandes empresas, mas para outros fins, tais como o controle dos processos ocorrendo no empreendimento (AZEVEDO, 2006). Contudo, não se encontrou informação do uso desses softwares para 
a aplicação do conceito de Ecologia Industrial às empresas ou para a formação de ecossistemas industriais. Assim, é objetivo geral deste trabalho o desenvolvimento de metodologia para uso de softwares na aplicação do conceito de Ecologia Industrial em empresas da área de Eletroeletrônicos, preferencialmente ligadas à área de Microeletrônica, para:

a) definir indicadores de sustentabilidade adequados ao sistema;

b) indicar possíveis melhorias de processo pela aplicação do conceito de Ecologia Industrial e pela formação de Ecossistemas Industriais.

\section{ASPECTOS TEÓRICOS}

Este capítulo abordará os seguintes temas e nesta ordem: atores ambientais (stakeholders) e indicadores de sustentabilidade, conceitos de Ecologia Industrial, Produção Limpa e similares, software para controle de processos.

\subsection{Atores Ambientais (Stakeholders) E Indicadores De Sustentabilidade.}

A definição de sustentabilidade aqui será utilizada como a descrita na introdução neste trabalho. Contudo, é importante observar que existem diferentes abordagens. Em uma revisão bibliográfica recente, Adeodato (2005) observa que a definição é abordada historicamente há quatro décadas e por diferentes autores, mas que não há consenso, não tendo se firmado "sobre um referencial teórico mais preciso ... não existindo, portanto, uma significação única que lhe defina". Adeodato, citando Robinson, fala em sustentabilidade como "a persistência por longo período, de certas características necessárias e desejáveis de um sistema sócio-político e seu ambiente natural, não infinitamente durável, mas que seja capaz de transformar a sociedade" e, também cita, especificamente para comunidades, como outras categorias importantes que delimitam sustentabilidade, além do tempo, espaço, tendência, dimensões, participação, coletividade.

Como discutido anteriormente, a sustentabilidade depende de aspectos ecológicos, econômicos e sociais. De fato, a Agenda 21, em seus 40 capítulos apresenta tais considerações, uma vez que as quatro seções que a compõe abordam: Dimensões Sociais e Econômicas (capítulos 2 a 8), Conservação e Gestão dos Recursos para o 
Desenvolvimento (capítulos 9 a 22), Fortalecimento do Papel dos Principais Grupos Sociais (capítulo 23 ao 32), Meios para Implementação. O capítulo 40 "Informações para a tomada de decisão" sugere que se definam padrões de sustentabilidade que considerem aspectos ambientais, econômicos, sociais, éticos e culturais.

Young (1997), porém, observa que a solução de muitos problemas ambientais, tais como as transformações atmosféricas, necessita também de comunicação entre "cientistas e não cientistas" e que medir a sustentabilidade "de um modo que todos possam entender é um desafio". Assim, Young propõe que se defina um framework assumindo-se inicialmente que "ecossistema, economia e sociedade são partes iguais da sustentabilidade". Portanto, a proposta de indicadores deixa implícita a necessidade de definir atores da questão ambiental. A necessidade de comunicação com vários atores distintos também foi levantada por Gameiro (2002) quando sugeriu a formação de ecossistemas industriais para a água, no início da cadeia de produção de eletroeletrônicos. Gameiro também lembra que essa comunicação é diferente do que normalmente se considera nas normas ambientais, tais como a série ISO, porque é de nível intermediário, devendo se estabelecer entre empresas principalmente.

\subsubsection{Atores Ambientais}

De acordo com o relatório técnico da ONU (Organização das Nações Unidas) muitos são os atores da questão ambiental que devem ser informados sobre as condições de um empreendimento. Deve-se exigir a comunicação dos impactos ambientais causados pelo produto, entre outras coisas, por exigências de várias normas, como as da série ISO 14000. Assim, há diferentes comunidades e entidades a serem atingidas por esta comunicação e a UNEP (United Nations Environmental Program), como demonstra o manual de indicadores para a comunicação ambiental por ela desenvolvido (UNEP, 2002), propõe formas e públicos a serem atingidos. A Tabela 1.1 mostra o público a ser atingido pela comunicação e as principais dúvidas desse público, de acordo com o manual citado. Assim, há muitas informações a serem obtidas e o manual em questão sugere que estas sejam obtidas inicialmente através do cumprimento do que é sugerido na norma ISO 14001. 
Tabela 1.1 Público a ser atingido pela comunicação ambiental e as principais dúvidas desse público, de acordo com o manual da UNEP.

\begin{tabular}{|c|c|}
\hline $\begin{array}{c}\text { Público a ser atingido } \\
\text { pela comunicação } \\
\text { ambiental }\end{array}$ & Principais dúvidas desse público \\
\hline Comunidade & Medo do desconhecido \\
\hline Ong & Medo da falta de dados \\
\hline Governo & Medo da falta de dados \\
\hline Consumidores & Desejo de agir ambientalmente correto \\
\hline Imprensa & Medo de não obter a verdadeira história, principalmente \\
Associações & $\begin{array}{c}\text { porque também podem representar o empreendimento em } \\
\text { alguns fóruns }\end{array}$ \\
\hline Instituição financeira & Medo de que haja perigo futuro no empreendimento \\
\hline Acionistas & Medo de que haja perigo futuro no empreendimento \\
\hline
\end{tabular}


A norma ISO 14001 exige que sejam cumpridas a legislação, as diretrizes e as recomendações a que o empreendimento onde está sendo implantada a norma esteja sujeito. Portanto vários indicadores de sustentabilidade são propostos, não só pela ISO 14031 mas também por diferentes associações e alguns serão sucintamente descritos a seguir.

\subsubsection{Indicadores de Sustentabilidade}

Vários atores ambientais preocuparam-se com a questão da sustentabilidade e propuseram diferentes abordagens baseando-se na similaridade entre as atividades humanas com as biológicas. Andrade (2001) analisou várias correntes filosóficas preocupadas com a relação entre ambiente e desenvolvimento tecnológico e aponta interpretações interessantes. Por exemplo, Andrade cita a sustentabilidade advinda do "processo através do qual a natureza e a tecnologia, aparentemente duas metades díspares e incompatíveis da realidade, efetuariam uma resolução, uma integração, e formariam um sistema. ... o objeto técnico representa um ponto de encontro entre o meio geográfico e o meio técnico, formando uma combinação essencial e indissolúvel, e da qual depende sua existência e performance" ... "Compreender a relação entre técnica e ambiente implica também em atentar para a conformação dos ciclos técnicos", porém, "o grande impasse da construção do desenvolvimento sustentável reside no choque entre a temporalidade da produção global de mercadorias e as temporalidades físicas e bióticas. Enquanto essas últimas envolvem intervalos de tempo amplos e mudanças imperceptíveis para a capacidade humana de apreensão, a economia capitalista se desenvolve diminuindo os ciclos de acumulação do capital", mas os ritmos naturais e sociais ... "podem se compatibilizar, formando um sistema complexo e variável em que entram os diferentes domínios da vida social ... A lentidão dos processos sociais e o caráter muitas vezes explosivo da concretização técnica estabelecem um "timing" específico que gera, ao mesmo tempo, um aperfeiçoamento dos conjuntos e um acoplamento orgânico com as outras dimensões sociais ...".

Pelo aspecto tecnológico também há abordagens explorando as similaridades das atividades humanas com as biológicas. Um exemplo, citado em Lems (2003), é a 
comparação dos processos biológicos para conversão de energia solar com as atividades humanas, como a células solares. Assim, os autores propõem que a avaliação do processo pelo aspecto tecnológico leve em consideração uma análise termodinâmica dos processos e três aspectos e/ou indicadores: a) de sustentabilidade na utilização de recursos, através da avaliação das entradas termodinâmicas requeridas e da disponibilidade dos recursos para o processo; b) da eficiência através das perdas ocorridas na transformação e c) de compatibilidade ambiental, considerando as necessidades para prevenir impactos ambientais. A necessidade de descrever a matéria-prima não apenas como renovável ou não, mas também sua taxa de consumo é outra questão prioritária e que permite a definição de vários graus de matéria "renovável" (CHEM, 2002).

Em sua revisão sobre Ecologia Industrial, Giannetti (2006) aborda indicadores ambientais e observa que a ISO identifica três tipos de indicadores:

a) Voluntário, normalmente baseado no $\mathrm{ACV}$, e que corresponde à obtenção de um rótulo, conhecido como o "selo verde";

b) Relatórios públicos ambientais divulgados no rótulo do produto, como por exemplo "reciclável";

c) Programa voluntário que forneça dados quantitativos sobre o desempenho ambiental de determinado produto. Útil para a melhoria de processos.

Os indicadores ambientais, de acordo com a ISO 14031, são de duas categorias: os de desempenho ambiental e os de condições ambientais. Além disso, os indicadores também podem ser considerados como: indicadores absolutos (dados básicos sem análise ou interpretação), indicadores relativos (comparam dados com outros parâmetros), indicadores agregados (agregam dados de mesmo tipo, mas de fontes diferentes) e indicadores ponderados (mostram a importância relativa de um indicador em relação ao outro).

Os indicadores de interesse deste trabalho são os absolutos, como propostos pela ISO 14031. Quanto aos indicadores de desempenho, são relevantes os que favorecem a implantação da Ecologia Industrial, ou seja, os de cunho operacional, a saber:

a) Fluxo de materiais:

- entrada de materiais (materiais processados, reciclados, matéria-prima, etc.);

- produção (produto principal, subprodutos, reciclado, etc.); 
- resíduos (sólidos, líquidos, gasosos, perigosos e não-perigosos, recicláveis, reutilizáveis);

- emissões (ruídos, radiações, etc.);

b) Uso de recursos naturais energia e serviços;

c) Projeto, instalação, operação;

d) Manutenção das instalações e equipamentos.

No setor secundário, as bolsas de valores têm prestado enorme contribuição para a proposta de obtenção de indicadores de sustentabilidade. No país a BOVESPA criou o Índice de Sustentabilidade Empresarial (ISE, 2006) e processo semelhante ocorreu com o conselho empresarial brasileiro de desenvolvimento sustentável (CEBDS, 1997). Este trabalho compilou tais indicadores e os apresenta no Anexo 1. A esses indicadores são também feitos comentários no referido Anexo, em relação ao conceito de Ecologia Industrial, como será abordado posteriormente. Estes indicadores são similares em muitos aspectos aos exigidos pelas normas ISO e também aos propostos pela Coalition for Environmentally Responsible Economies (CERES) no seu Global Reporting Initiative (GRI, 2006).

A Agenda 21 deve ser adequada a cada localidade, assim surgiram as "Agendas 21 locais”, e com estas, também indicadores de sustentabilidade. A procura de indicadores para a cidade mostra certa correlação com o que ocorre com o setor secundário. Dentre as cidades que desenvolveram trabalho nessa área Seatlle é um bom exemplo porque criou o programa "Seattle Sustentável" há mais de uma década, praticamente em conjunto com a Eco-92. Nesse programa quarenta indicadores foram levantados por uma equipe multidisciplinar, e encontram-se listados no Anexo 2. É importante observar que para alguns indicadores não houve consenso em como interpretá-los. Assim, enquanto os responsáveis pelos indicadores econômicos consideram o aumento populacional um indicador positivo de sustentabilidade os envolvidos com valores de impacto ambiental não. Outra questão relevante é que os indicadores podem se ligar de modo complexo, havendo, por exemplo, correlação entre pobreza infantil e diminuição de salmão selvagem no rio.

Grandes cidades no país desenvolveram trabalho semelhante. Recentemente São Paulo (GEO, 2004) e Rio de Janeiro também estabeleceram seus parâmetros, que se 
assemelham ao proposto por Seattle. Mesmo para empreendimentos aparentemente distantes da cidade, tanto fisicamente como na questão da prioridade, como são os empreendimentos industriais, tem-se propostas de indicadores de sustentabilidade. Prédios industriais que foram desativados receberam atenção especial no Reino Unido e um programa (Sustainable Cities Programme) do Engineering and Physical Sciences Research Council, que estudou a região de Stoke-on-Trent, propôs modos de reuso de tais localidades (BALL, 2001). A avaliação do reuso de tais localidades mostrou que os envolvidos nesse reaproveitamento, muito embora não tenham claro o conceito de sustentabilidade, apresentam uma atitude positiva e tendem a encontrar soluções práticas que estão de acordo com o conceito de desenvolvimento sustentável. Outra abordagem importante são os indicadores durante a construção dos empreendimentos, o que leva à noção de construções sustentáveis e à preocupação da definição desses indicadores para os tomadores decisão, o que em geral também é feito via framework (PEARCE, 2002).

\subsection{Ecologia Industrial}

Os conceitos de "metabolismo industrial" e "Ecologia Industrial" têm-se manifestado ao longo das últimas três décadas, ainda que de forma dispersa. A idéia de descrever os fluxos de material e energia, inerentes aos processos industriais, como um sistema metabólico, foi introduzida por Robert U. Ayres, que cunhou o termo "metabolismo industrial" (EHRENFELD, 1997). O conceito se fundamenta, basicamente, na aplicação do princípio de equilíbrio de massas à circulação de materiais e energia ao longo dos processos produtivos.

O conceito de Ecologia Industrial, entretanto, deve ir além. Erkman (1997) entende que, a partir do conhecimento de como os sistemas industriais funcionam e são regulados, de suas interações com a biosfera e do conhecimento disponível sobre meio ambiente, esses sistemas seriam reestruturados para compatibilização com os ecossistemas naturais. $\mathrm{O}$ autor reconhece que muitos outros autores não fazem distinção entre os dois ecossistemas, ainda que a considere necessária, e observa que: 
- A analogia entre processos industriais e metabolismo esteve em uso durante a década de 80, desenvolvida em diversos trabalhos e em diferentes países (Estados Unidos, Áustria, França e Suíça), mais ou menos paralelamente.

- A idéia de ecossistema industrial começou a surgir na década de 70. Há algum tempo, certos ecologistas percebiam o sistema industrial como um subsistema da biosfera da qual demandam recursos e serviços. Teriam, portanto, que ser analisados conjuntamente. Uma das primeiras ocorrências do termo "ecossistema industrial" pode ser encontrada em um artigo de 1977 do geoquímico americano Preston Cloud, apresentado no Encontro Anual da Associação Geológica Alemã. Em 1976, no seminário promovido pela Comissão Econômica para a Europa, da ONU, os diversos artigos tratando do que foi chamado "tecnologia e produção sem resíduos" continham idéias semelhantes às discutidas hoje na Produção Mais Limpa e na Ecologia Industrial. A ONU convidou a empresa $3 \mathrm{M}$ para apresentar, naquele seminário, os resultados do seu programa 3P, isto é, a Prevenção da Poluição se Paga. Já na época, a empresa sustentava que, além de ganhos ambientais, um programa de prevenção da poluição trazia também ganhos econômicos (SHEN, 1995).

Até os anos 80, ocorreram tentativas de discussão do novo conceito, mas com pouco resultado. No início da década, Charles Hall, ecologista da Universidade do Estado de Nova York, começou a ensinar o conceito de ecossistemas industriais e a publicar artigos a respeito; na mesma época, em Paris, Jacques Vigneron também lançou a noção de Ecologia Industrial, mas os conceitos de Prevenção da Poluição e Ecologia Industrial somente se afirmam no final desta mesma década. Em 1989, a Agência Ambiental dos Estados Unidos da América, USEPA, cria o seu escritório de Prevenção da Poluição. Ainda em setembro do mesmo ano, foi publicado um artigo de Robert Frosch e Nicholas Gallopoulos, na Scientific American, que é uma referência na consolidação e valorização do conceito. O título proposto pelos autores foi "Manufatura - A Visão do Ecossistema Industrial", mas o artigo foi publicado com o título "Estratégias de Manufatura". Nele, os autores argumentam ser possível desenvolver métodos de produção menos danosos ao meio ambiente, substituindo-se os processos isolados por sistemas integrados que chamaram de ecossistemas industriais. Esses modificariam, tanto quanto possível, a lógica de produção isolada, baseada apenas na utilização de matérias primas resultando 
em produtos e resíduos, substituindo-a por sistemas que possibilitassem o aproveitamento interno de resíduos e subprodutos, reduzindo as entradas e saídas externas. Desse processamento interno vem a analogia com os sistemas ecológicos.

É importante observar que um outro termo, além de resíduo e subproduto, aparece na descrição de sistemas: não produto (non product). Por exemplo, Young (2000) propôs que a produção de não produtos fosse penalizada em um sistema de avaliação de impacto ambiental, mas que isso não ocorresse se este não produto recebesse outra aplicação. $O$ termo non product também foi citado por Rossi (2000) como um dos indicadores proposto pela CERES no GRI e corresponde "ao que atinge o solo e deve ser definido quanto ao tipo de material e se está dentro ou não do local de produção"1. No país, o setor secundário utiliza o conceito de co-produto (SOUZA, 2001) como aquele material produzido involuntariamente, mas que pode ser reutilizado em outro ponto do processo (internamente à produção) ou mesmo em outro processo (externamente à produção). Petain (2001) dá como "exemplo de receita, relacionada com a proteção ambiental, o caso do enxofre, que é produzido pelas minerações de carvão (folhelho e xisto), pela metalurgia do cobre e pelas refinarias de petróleo, sendo recuperado nos filtros e em outros equipamentos de coleta de resíduos, como medida de proteção ambiental e controle da poluição." Neste trabalho o termo co-produto será usado neste contexto.

A partir do início dos anos 90, o conceito de Ecologia Industrial passou a ter um considerável impulso e ressonância, sem precedentes em relação ao considerável tempo anterior em que tal concepção vinha sendo abordada, e até praticada, mas sem merecer maior atenção e alguns exemplos de seu uso são dados a seguir. O Japão é um exemplo ímpar de estudos contínuos nesse sentido patrocinados pelo governo. Já em 1970, um dos grupos de trabalho formados por indução do Conselho da Estrutura Industrial, para analisar o ajuste da atividade econômica ao contexto ambiental, denominou-se "Grupo de Trabalho da Ecologia Industrial". Desde então, o governo tem patrocinado esforços no sentido da substituição de recursos ambientais por tecnologia. (ERKMAN, 1997).

Na Bélgica, em 1983, o Centro de Pesquisa e Informações Sociopolíticas, um centro de pesquisas independente, publicou um trabalho coletivo intitulado: "O Ecossistema Belga - Ensaio de Ecologia Industrial" (ERKMAN, 1997). O trabalho foi desenvolvido

\footnotetext{
1 "quantity of non-product output to land by material type and by on- and off-site management"
} 
de forma autônoma por seis pesquisadores de diferentes áreas (biólogos, químicos e economistas), que pretenderam apresentar uma visão de conjunto da economia belga, avaliada a partir do fluxo de materiais e energia em contraposição às tradicionais unidades econômicas abstratas. $\mathrm{O}$ grupo estudou seis cadeias principais: aço, chumbo, vidro, plástico, madeira e papel, e produção de alimentos. Um dos principais elementos identificados foi a grande desconexão entre atividades que, se integradas, reduziriam os consumos globais de energia e matéria-prima e a produção de resíduos. Um exemplo característico era a separação completa que tinha ocorrido gradativamente, com o progresso, entre lavoura e criação, as quais, se desenvolvidas de forma integrada, possibilitariam uma considerável retroalimentação, reduzindo as entradas e saídas externas ao conjunto. Uma parcela da produção da lavoura destina-se à alimentação dos animais e o mesmo pode ocorrer com boa parte dos resíduos. Por outro lado, os excrementos das criações que, se considerados de forma isolada, constituem-se em resíduos a descartar, quando encarados em um processo produtivo integrado tornam-se úteis às lavouras, reduzindo a necessidade de fertilizantes industrializados.

$\mathrm{O}$ estudo concluiu que o funcionamento do sistema industrial belga produzia três tipos de disfunções: os ciclos de materiais, totalmente abertos, levavam os resíduos, que poderiam ser matéria-prima de outros processos, a serem tratados como lixo, com as dificuldades próprias da disposição; a operação de tal sistema implicava grande desperdício de energia; e a estrutura de circulação de materiais produzia poluição. Contestava, ainda, a concepção de que o aumento de resíduos fosse inerente ao aumento da produção e do consumo, atribuindo-o, especialmente, ao funcionamento do sistema. Apesar do alcance do trabalho, na época, a proposta teve pouca receptividade.

O Parque Industrial de Burnside, Dartmouth, Canadá estabeleceu-se na década de 70 em uma zona de comércio e indústrias leves e é constituído de um número muito grande de pequenas empresas. Coté e Smolenaars (1997) desenvolveram um estudo de caso aplicado ao parque, com o objetivo de transformá-lo em um "eco-parque". Identificaram dificuldades e propuseram intervenções e elementos a serem desenvolvidos para provocar essa transformação. Entre as dificuldades arrolaram a grande superposição de empresas da mesma área, naturalmente concorrentes entre si, o que complica o estabelecimento das cadeias de produção integrada, a falta de informação e a resistência 
das mais antigas à mudança. Constataram que, dentre os resíduos que poderiam ser reaproveitados, sobressaíam as embalagens, de vários tipos, os óleos usados e os materiais provenientes da demolição dos edifícios mais antigos do próprio parque. Propuseram, então, o incentivo à instalação de empresas de reciclagem das embalagens e de recuperação dos óleos, e de uma central de transformação dos materiais de demolição para reuso nas novas construções do próprio parque. Como propulsão e apoio à transformação, propuseram os recursos que têm sido considerados fundamentais pela Ecologia Industrial: disseminação de informações técnicas quanto a possibilidades de recuperação, reciclagem e reuso; instrumentos econômicos de incentivo à mudança; e ajuste dos regulamentos, quando necessários.

Existem referências importantes sobre as experiências em Brownsville, nos Estados Unidos, em Stirya, na Áustria, e na região do Ruhr, na Alemanha. Contudo, a experiência mais marcante é o parque industrial de Kalundborg, na Dinamarca, citado, freqüentemente, como a melhor evidência da viabilidade prática de um ecossistema industrial. É composto por um número relativamente pequeno de empresas de grande porte e desenvolve o processo desde a década de 70. Atribui-se ao número limitado de participantes e à competência de seus administradores o resultado obtido até então. Existe a preocupação de que a pouca diversidade de parceiros possa, eventualmente, não ser capaz de assegurar a continuidade do fluxo interno, mas se considera, por outro lado, que a possibilidade existente de múltiplas entradas e saídas pode vencer esse risco (COTÉ e SMOLENAARS, 1997).

\subsubsection{Ecologia Industrial, Prevenção de Poluição e Produção Limpa}

Outros conceitos, além de Ecologia Industrial, são utilizados na tentativa de garantir sistemas sustentáveis e, como observa Gianetti (2006), muito embora tais conceitos sejam similares apresentam algumas particularidades que os distingue. A UNEP (United Union Environmental Program, 1989) considera como os mais importantes: 
- Produção Limpa: é a contínua aplicação de uma estratégia ambiental preventiva e integrada, aplicada a processos, produtos, e serviços para aumentar a eco-eficiência e reduzir riscos humanos e ao ambiente". Aplicada a processos prevê a "conservação de matérias primas e energia, eliminação de matérias primas tóxicas e redução na quantidade e toxidade de todas emissões e resíduos". Em relação a produtos: "redução nos impactos negativos ao longo do ciclo de vida do produto, da extração da material prima até a disposição final". Para serviços pressupõe "incorporação de conceitos ambientais dentro do projeto e execução dos serviços".

- Eco-eficiência: segundo o WBCSD (World Business Council for Sustaintable Development), "é alcançada pela entrega de produtos e serviços com preços competitivos, que satisfaçam as necessidades humanas, que contribuam para melhoria da qualidade de vida, enquanto progressivamente reduz os impactos ambientais e o consumo de recursos em todo o ciclo de vida, atingindo um nível que esteja de acordo com a capacidade da terra de prover".

- Prevenção de poluição: usado como sinônimo de prevenção na fonte. Foca a continua diminuição da poluição e do impacto ambiental pela diminuição na fonte da produção de resíduos.

- Minimização de resíduos: introduzido pela agência ambiental Americana (EPA) em 1988, corresponde a diminuição de resíduos na fonte produtora pela mudança em matéria-prima, tecnologia, práticas de operação ou mudanças de produto.

- Produção verde (Green Productivity): definida pela Asian Productivity Organization (APO), trata-se de uma estratégia para aumentar produtividade e performance ambiental para conseguir um melhor desenvolvimento sócio-econômico, em última instância, almejando o desenvolvimento sustentável.

Para a Ecologia Industrial, a UNEP cita como os seis principais elementos:

1.Criação de ecossistemas industriais: maximizando o uso de materiais reciclados na produção, otimizando o uso de materiais e energia, minimizando a formação de resíduos, reavaliando "resíduos" como matéria-prima para outros processos.

2. Balanceamento das entradas e saídas do sistema industrial em relação à capacidade do ecossistema: entender a capacidade do sistema natural em interagir com os produtos tóxicos e resíduos em situações catastróficas. 
3. Desmaterialização na saída industrial: reduzindo materiais e consumo de energia na produção industrial.

4. Melhoria dos caminhos metabólicos nos processos industriais e uso de materiais: reduzindo ou simplificando processos industriais para emular processos naturais, altamente eficientes.

5. Processos sistêmicos de uso de energia: promover o desenvolvimento de processos de fornecimento de energia que funcionem como parte do ecossistema industrial e que estejam livres de impactos negativos ao uso da energia.

6. Política alinhada com uma perspectiva de longo prazo para evolução do sistema industrial, com nações trabalhando em conjunto para integrar políticas econômicas e ambientais.

\subsubsection{Considerações sobre as posições dos defensores da Produção Mais Limpa e} da Ecologia Industrial

Historicamente, as principais incompatibilidades com a prevenção da poluição seriam: a valorização da reciclagem, a redução da eficiência no uso dos materiais nos processos e o aumento dos riscos. (OLDENBURG e GEISER, 1997). Alguns defensores da prevenção da poluição fizeram críticas enfáticas à Ecologia Industrial e estabelecem comparações desfavoráveis entre ambas. Consideram que a prevenção da poluição já tem um histórico de resultados a apresentar e seus mecanismos já conseguiram um significativo ganho ambiental nos processos produtivos. Forçadas, por regulamentos e pela opinião pública, a reduzir as pressões sobre o meio ambiente, as empresas obtiveram, em paralelo, ganhos econômicos pelo aumento da eficiência dos processos. Essa experiência, que já permite somar ganhos ambientais com melhoria da imagem perante os consumidores e ganhos econômicos, mantida a pressão legal, determinaria um movimento crescente do sistema produtivo no sentido da adoção de tecnologias limpas.

Por outro lado, a Ecologia Industrial, que ainda tem poucos resultados a apresentar, segundo Commoner (1997), teria uma fundamentação teórica vaga, aumentaria riscos e não incentivaria a inovação tecnológica. As críticas à fundamentação teórica vão desde considerar a teoria como a soma de várias outras, à argumentação de que se basearia em 
um princípio falso, uma vez que, há muito tempo, não existiriam sistemas naturais intactos que pudessem servir como referência. Os riscos então seriam devidos à admissão da produção e manejo de produtos perigosos para alimentação de outro processo ou reciclagem, inclusive por áreas externas às zonas industriais, o que submeteria a riscos, tanto os trabalhadores envolvidos com os processos como as comunidades vizinhas. A pretensão de flexibilizar as leis aumentaria esse risco, reintroduzindo elementos danosos que já estariam a caminho de serem ultrapassados. Da mesma forma, admitindo e incentivando a reciclagem, a Ecologia Industrial estaria defendendo um procedimento já considerado em um degrau inferior na hierarquia das alternativas para a redução dos impactos ambientais. Admitindo processos menos eficientes e flexibilizando as leis, o desenvolvimento tecnológico deixaria de ser incentivado.

A Ecologia Industrial visa, tanto quanto a Prevenção da Poluição ou a Produção Mais Limpa, prevenir a poluição, reduzindo a demanda por matérias-primas, água e energia e a devolução de resíduos à natureza. Porém, enfatiza a sua obtenção através de sistemas integrados de processos ou indústrias, de forma que resíduos ou subprodutos de um processo possam servir como matéria-prima de outro. Difere, nesse ponto, da Produção Mais Limpa, que prioriza os esforços dentro de cada processo, isoladamente, colocando a reciclagem externa entre as últimas opções a considerar.

$\mathrm{Na}$ Ecologia Industrial, parte-se da consideração de que, por mais que se aperfeiçoem os processos de produção, sempre poderá ocorrer a geração de algum resíduo ou subproduto, para os quais não haja uma alternativa economicamente viável, se o processo for considerado de forma isolada. Alternativamente, a empresa poderá não ter interesse em desenvolver outro processo que o aproveite. A integração adequada de diferentes empresas, de forma que os resíduos (agora denominados co-produtos) e subprodutos gerados por uma delas possam servir de matérias-primas para outras, reduziria a devolução à natureza. Desta forma, a sua utilização como matéria-prima reduziria a demanda por novos recursos naturais.

Considera-se, também, a possibilidade de recuperação da energia armazenada nas ligações químicas, especialmente nos sintéticos, que a têm acumulada em quantidade e que são produtos cuja devolução à natureza é especialmente perigosa. Prevê-se, ainda, a hipótese de armazenagem, ao invés de deposição definitiva, de resíduos para os quais se 
vislumbre uma possibilidade de utilização posterior, como determinados metais ou suas associações. A pretensão é desenvolver ciclos de produção, distribuição, consumo e devolução de resíduos tão fechados quanto possível.

Além da redução da demanda e da restituição ao mínimo inevitável, os resíduos que não pudessem ser suprimidos, no fim de todo o ciclo, seriam tornados o mais compatíveis possível com o processamento natural, antes da devolução ao ambiente. O sentido geral é de, por meio de um sistema industrial e dos reaproveitamentos e transformações possíveis, utilizar ao máximo os recursos naturais inevitavelmente necessários, reduzindo a um mínimo a pressão sobre a natureza, tanto do lado da demanda quanto do da restituição.

A lógica de processamento interno de materiais e energia, com a recuperação de valores incorporados aos resíduos e/ou co-produtos que seriam rejeitos de alguns processos, por sua utilização como alimentação de outros, é que leva à associação com a ecologia. O modelo ideal de referência seriam os sistemas naturais fechados, nos quais não cabem os conceitos de resíduos e matéria-prima. Não sendo possível repeti-los, procurar-se-ia aproximar-se deles o mais possível, reduzindo as pressões externas. "Um ecossistema industrial é a transformação do modelo tradicional de atividade industrial, no qual cada fábrica, individualmente, demanda matérias-primas e gera produtos a serem vendidos e resíduos a serem depositados, para um sistema mais integrado, no qual o consumo de energia e materiais é otimizado e os efluentes de um processo servem como matéria-prima de outro." (FROSCH e GALLOPOULOS, 1989).

Os materiais e a energia, em uso ou incorporada, são vistos como elementos de um fluxo que, temporariamente, assumem uma determinada conformação que pode ser transformada posteriormente. "Vamos considerar a indústria, ou, na realidade, toda a humanidade e a natureza, como um sistema de armazenagem temporária e de fluxos de materiais e energia (...) Para essa discussão a energia é considerada no nível químico, não no nuclear; os elementos permanecem os elementos que são. Por exemplo, plásticos polímeros - são vistos menos como um material específico do que como coleções de átomos de carbono, hidrogênio (...) agrupados pela energia das reações químicas. Os processos da indústria reagrupam os átomos em várias coleções ou misturas de elementos ligados energeticamente. (...) Neste sentido os produtos são apenas instâncias no fluxo de 
materiais e energia - uma armazenagem temporária de elementos e energia de ligações químicas (...) Essa perspectiva é simplista mas (...) pode sugerir algumas linhas úteis de pensamento." (FROSCH, 1996).

Ainda que preconize a redução de resíduos ao longo dos processos, a Ecologia Industrial considera que pode ser admitida, ou que até seja útil, a geração de algum resíduo ou subproduto, em um determinado processo, se esse servir como matéria-prima para a empresa seguinte da cadeia, contribuindo, assim, para a manutenção do fluxo. “(...) em certos casos, a abordagem da Ecologia Industrial poderá mesmo considerar o aumento da produção de um determinado resíduo, na ausência de uma alternativa de Produção Mais Limpa viável, se isso tornar possível a transformação do resíduo em um subproduto comercializável.” (ERKMAN, 1997). Esta avaliação é contrária a Produção Limpa e/ou Prevenção de Poluição. Contudo, essas duas correntes que, devido à sua abrangência, representam mais do que apenas duas correntes do pensamento ambiental, apresentam algumas diferenças significativas, que muitos consideram como complementares. Ambas pretendem prevenir a poluição na fonte, sendo que para uma a fonte é, essencialmente, cada processo, e para a outra pode ser um conjunto de processos ou indústrias. Utilizam importantes ferramentas comuns de análise, como avaliação do ciclo de vida, projeto para o meio ambiente, total de material consumido, custo total e avaliação dos processos de produção. As duas procuram redirecionar as preocupações com o meio ambiente da periferia do processo produtivo para o seu interior. Ambas identificam a falência dos procedimentos que privilegiam as chamadas medidas fim-de-tubo, sem contudo descartar a sua importância relativa.

Portanto, as diferenças marcantes estão na ênfase dada à reciclagem e, conseqüentemente, à menor exigência de eficiência na utilização de materiais em cada processo pela Ecologia Industrial, e o aumento dos riscos decorrentes dos procedimentos por ela admitidos. Assim, as críticas mais procedentes são quanto ao aumento dos riscos e à flexibilização das leis. A Ecologia Industrial também defende a otimização dos processos, considerando-se a reciclagem como um elemento a mais para a redução dos resíduos inevitáveis por outros métodos. A crítica é primária quanto ao fato de que a não existência de sistemas naturais intocados, que possam servir como referência, 
prejudicaria a fundamentação da teoria. O que se pretende é perseguir a lógica de ciclos fechados e não apenas copiar a natureza.

Existe uma questão de fundo estratégico na ênfase da Produção Mais Limpa pela busca de emissão zero, relegando-se a reciclagem a um patamar de terceira importância: orientar todos os esforços, o mais possível, para a maior eficiência da produção. A admissão de alternativas poderia reduzir esse esforço. A Produção Mais Limpa só admite a reciclagem externa ao processo como um último recurso para a redução de resíduos impossíveis de serem evitados, mas isso representa o reconhecimento de que ainda podem ocorrer resíduos apesar da prevenção da poluição. A própria lógica do processo de Produção Mais Limpa inclui a compreensão de que não há processo inteiramente limpo e de que a limpeza possível hoje é menor do que será possível amanhã, e ainda existem muitos resíduos atualmente, após os programas de prevenção da poluição.

A necessidade de se flexibilizar a legislação ambiental ou a sua aplicação, para a implantação da Ecologia Industrial, não significa relaxamento ou redução dos padrões vigentes ou a possibilidade da própria indústria determinar o que pode ou não ser admitido como práticas ambientalmente corretas. Consultores de grandes corporações, como Michael Porter (PORTER e LINDE, 1995), são enfáticos ao afirmar que níveis mais altos de exigência ambiental não são apenas indispensáveis para a proteção do meio ambiente, como se constituem em fatores de aumento de competitividade. A evolução da legislação ambiental e dos mecanismos para sua aplicação deve permitir que soluções de melhor qualidade, ambiental e econômica possam ocorrer. Trata-se, pois, de um problema de otimização, no caso com múltiplos objetivos, tanto para a Produção Mais Limpa como para a Ecologia Industrial.

Sempre que se consideram problemas de grande complexidade, com inúmeras variáveis e várias funções-objetivo, surgem regras heurísticas para decompor o problema e torná-lo acessível a setores profissionais e sociais mais amplos. É o caso da busca da produção com resíduo zero. Os defensores da Produção Limpa indicam uma sequiência de intervenções onde são priorizadas as medidas a montante do processo produtivo. Medidas de reciclagem ou reuso externo são colocadas em um patamar menos nobre. Já os defensores da Ecologia Industrial identificam enormes oportunidades para a minimização de resíduos nas interfaces entre plantas industriais, elos de uma determinada cadeia 
produtiva, ou entre setores produtivos. Não se trata de posturas divergentes quanto ao que se procura atingir. Nem sequer se trata de divergência dos mecanismos para se atingir uma sociedade com melhor desempenho quanto à produtividade dos recursos naturais. Trata-se de uma divergência quanto à forma de decompor um problema com o nível de complexidade como o proposto. Dividir o problema da busca de produção com resíduo zero entre um subproblema intrafábrica e outro interfábricas é uma forma de se decompor um problema complexo em dois subproblemas, cada um com um número menor de graus de liberdade. Assim sendo, ao encarar-se um problema de minimização de resíduos focando-se apenas variáveis internas à empresa, ou apenas formas de integrar várias empresas, pode-se encontrar uma boa solução, ambiental e economicamente falando, melhor que aquela vigente. Dificilmente, porém, pode-se considerá-la como a melhor possível. Por outro lado, procurando resolver os problemas sem os decompor, no intuito de identificar um ótimo global, pode-se adiar a implementação de melhorias de grande significância na espera de soluções ainda melhores.

\subsubsection{Ferramentas da Ecologia Industrial e da Produção Limpa}

Várias ferramentas e metodologias são usadas para se definir se um sistema esta de acordo com o conceito de Ecologia Industrial. Silva (2004) argumenta que para a Ecologia Industrial "A existência de "resíduos", ou seja, material que se acumula em alguma região também pode ser encontrado nos ecossistemas vivos: salitre, petróleo e ferro são alguns exemplos de acumulação de dejetos advindos de organismos vivos. $\mathrm{O}$ importante é como estes dejetos interagem com o meio ambiente...." Nos sistemas naturais os produtores primários correspondem àqueles seres que fornecem uma grande quantidade de matéria-prima ao meio. São portanto, similares aos setores mais básicos da economia, como o petrolífero e de extração mineral. Nestes sistemas ciclos internos, devido à grande quantidade de produção, são fáceis de serem obtidos, na automobilística a reciclagem de partes e peças, aliada à desmaterialização, tornou o setor bastante desenvolvido. Quando a matéria-prima escasseia nos sistemas naturais, uma série de estratégias começa a se tornar mais evidente. O mesmo tem ocorrido nos sistemas industriais: desmaterialização; substituição de materiais, com ênfase na reciclagem, no 
desenvolvimento de processos para reciclagem e na "não mistura" de materiais tanto na produção (ecossistema em ciclo interno) quanto na reciclagem final (ecossistema em ciclo externo); redução e/ou eliminação de substâncias nocivas e que não possam ser convertidas ou consumidas, como, por exemplo, metal pesado no setor galvânico ou o chumbo no de eletroeletrônicos; desenho orientado à desmontagem, o que se tornou comum no setor de auto peças; extração de materiais úteis de resíduos, nesse caso exemplo clássico é a obtenção de metais a partir de resíduos de eletroeletrônicos existentes nas grandes cidades."

Uma ferramenta não mencionada por Silva e de extrema importância é a Análise do Ciclo de Vida (ACV). A ACV constitui-se em um elemento essencial para a Ecologia Industrial, como ferramenta indispensável para o melhor acompanhamento dos ciclos e a identificação de alternativas de interação de processos. Também o Projeto para o Meio Ambiente (Design for Environment) tem aumentado a sua importância pela necessidade de prever a integração de unidades ou sistemas. Por fim, aplicação das normas ISO de qualidade, meio ambiente e, futuramente, responsabilidade social, não deve ser esquecida.

Giannetti (2006) define como ferramentas históricas da Ecologia Industrial, o Projeto para o Meio Ambiente, a ACV e a contabilidade ambiental. O projeto para o meio ambiente examina todo o ciclo de vida do produto e propõe alterações no projeto, de forma a minimizar seu impacto ambiental. Posteriormente a rotulagem ambiental é também adicionada. Giannetti também informa que a UNEP não diferencia eco-eficiência de Produção Mais Limpa, mas que o WBCSD o faz, já que define Eco-eficiência "pelo trabalho direcionado a minimizar impactos ambientais, devido ao uso minimizado de matérias-primas: produzir mais com menos”. Esta definição é semelhante à de ecodesign, como descrito posteriormente. A WBCSD sugere para se atingir a Eco-eficiência:
“a) reduzir a quantidade de matéria em bens e serviços;
b) reduzir a quantidade de energia em bens e serviços;
c) reduzir a dispersão de material tóxico;
d) aumentar a reciclagem de material;
e) maximizar o uso de fontes renováveis;
f) aumentar a durabilidade dos produtos; 
g) aumentar a quantidade de bens e serviços. ”

O metabolismo industrial é mais um conceito que uma ferramenta da Ecologia Industrial. Assim, considera-se que o metabolismo industrial "consiste nos processos físicos e químicos que convertem matérias-primas e energia em produtos e resíduos." (AYRES, 1989). Portanto, a avaliação dos sistemas industriais como composta por produtor, consumidor e reciclador implica no conhecimento dos fluxos de materiais do sistema industrial e pode ser considerado um fator relevante de sustentabilidade. Deste modo, o fluxo de materiais - e seu balanço de massa - em um processo, e em especial em um ecossistema industrial, é um indicador ambiental importante, porém, em um contexto distinto do sugerido para a eco-eficiência. Observe-se que a formação do ecossistema industrial é considerado a expressão máxima da Ecologia Industrial, e portanto sua melhor ferramenta.

Quanto às ferramentas úteis para a Produção Limpa, Silva (1998) sugere:

- "Tecnologias limpas e mais limpas: deve-se desenvolver tecnologias que tenham baixo consumo de material e energia e nenhum ou pouco impacto ambiental.

- Ecomateriais: é necessário o desenvolvimento de produtos capazes de permitir a reciclagem.

- Ecodesign: é necessário que os produtos desenvolvidos permitam um fácil desmonte, no intuito de permitir uma reciclagem custo-efetiva. Aqui, a idéia mostra conjunção com a Produção Enxuta.

- Responsabilidade continuada do produtor: para que a reciclagem ocorra ao fim do ciclo de vida do produto, é necessário que o produtor seja responsável pelo produto, mesmo depois da saída da indústria.

- Avaliação ambiental/avaliação de impacto ambiental: é necessário verificar, periodicamente, se medidas de prevenção de poluição podem ser tomadas. É preciso quantificar as perdas e compreendê-las dentro do processo. Antes do início de qualquer processo, por outro lado, é preciso avaliar como tais sistemas vão interferir no ecossistema.

- Avaliação do ciclo de vida: os materiais devem ser avaliados quanto ao tempo de vida que apresentam na natureza e seus respectivos impactos. 
- Saúde do trabalhador/educação ambiental: se o produto seguir as premissas da Produção Limpa, não haverá problemas de saúde no trabalho, uma vez que o sistema de produção deve ser bem compreendido pelo funcionário.

- Comunicação ambiental: deve-se exigir a comunicação de todos os impactos ambientais causados pelo produto."

Por fim, observe-se que de modo geral os autores anteriormente citados neste capítulo corroboram que as ferramentas descritas são necessárias para a obtenção da sustentabilidade, contudo, não relacionam tais ferramentas necessariamente com os conceitos de Ecologia Industrial ou Produção Limpa.

\subsubsection{Ecossistemas Industriais e Avaliação do ciclo de vida}

Devido à sua grande importância para a Ecologia Industrial, este trabalho dará ênfase à formação de ecossistemas industriais. Por outro lado, pela similaridade com os meios para aplicação do conceito de metabolismo industrial, ênfase também é colocada na avaliação do ciclo de vida.

\subsubsection{Ecossistemas Industriais}

Os "parques eco-industriais" são previstos como zonas industriais organizadas para funcionarem como sistemas integrados, dentro da perspectiva de processamento interno. São consideradas medidas estratégicas para seu bom funcionamento: 1) existência de uma autoridade para a gestão de resíduos no parque; 2) projeto e construção das unidades e infra-estrutura que enfatizem a eficiência energética e do uso de água, a utilização de fontes renováveis de energia, materiais ambientalmente benignos, e facilidade de desmontagem e reconstrução; 3) amplo serviço de informação ligando as companhias participantes, e 4) uma companhia gerenciadora do parque. Prevê-se, também, a 
possibilidade de as inter-relações de empresas ultrapassarem os contornos de uma zona industrial, abrangendo uma determinada região (LOWE, 1993). Erkman (1997) intitula esses sistemas de "ilhas de sustentabilidade".

As bases necessárias para a implantação dos ecossistemas industriais são: informação técnica, instrumentos econômicos e regulamentos. A primeira seria responsável por identificar e informar as possibilidades de integração, alternativas de mudanças de processo e procedimentos nesse sentido, e suas vantagens ambientais e econômicas. Os instrumentos econômicos seriam utilizados para fomentar as mudanças, principalmente incentivando as ações que proporcionassem ganhos ambientais. Quanto aos regulamentos, necessita-se de normas mais flexíveis, que assegurem maior espaço de decisão para as empresas. Constituem desafios e riscos que podem vir a ser barreiras para a formação dos ecossistemas industriais: 1) a quebra da cadeia de suprimento, se um dos participantes fechar ou modificar sua produção - é preciso haver um grau de variedade ou de flexibilidade que evite essa situação; 2) difusão de informações privadas; 3) riscos devidos à não-uniformidade dos resíduos ou subprodutos e a produtos tóxicos; 4) barreiras legais. (Lowe, 1993)

Ecossistemas industriais podem ser constituídos tanto por critérios de proximidade geográfica como de afinidade entre os processos produtivos. Distritos industriais tradicionais podem ser a base para um ecossistema industrial, tanto quanto as cadeias produtivas.(CAVALCANTI, 2001). Neste aspecto o trabalho de Abreu (2001), que avalia o setor petroquímico (Pólo Petroquímico de Camaçari) com um modelo de avaliação da Estratégia Ambiental, denominado de ECP-Ambiental (Estrutura-Conduta-Performance), é bastante revelador, uma vez que a autora considera "modelo geral de avaliação da estratégia não somente econômica, mas também ambiental e social”. O trabalho utiliza o conjunto de indicadores ambientais proposto pela OECD (Organization for Economic Co-Operation and Development) para traçar a performance ambiental. As conclusões da autora são mostradas a seguir.

O Pólo Petroquímico de Camaçari apresenta-se como uma oportunidade de alto potencial para atingir níveis elevados de eco-eficiência. Várias das características desejáveis de "eco-parques" podem ser nele encontradas. Há uma tradição de agir de forma integrada para equacionar problemas ambientais, a proximidade física e a 
integração industrial de várias gerações da cadeia petroquímica. A própria sensibilidade ambiental do sítio onde ele se localiza constitui-se em fator de pressão para atingir um desempenho ambiental de destaque, inclusive no âmbito internacional.

Algumas dificuldades poderão ser encontradas. O sistema de proteção ambiental do Pólo foi concebido como um sistema fim-de-tubo por excelência. $\mathrm{O}$ seu sistema de coleta, tratamento e afastamento de efluentes líquidos foi idealizado dentro da ótica da centralização do seu tratamento para posterior descarte. Isso pode ser atribuído à visão ambiental vigente na época da sua implantação apesar de que, na década de 70, propostas de controle da poluição na fonte já começassem a mostrar seus frutos em outros lugares do planeta.

O licenciamento da duplicação do Pólo, em 1989, permitiu uma discussão ampla e atualizada da questão ambiental na indústria. O então Conselho Estadual de Proteção Ambiental - CEPRAM, iniciou um deslocamento das medidas de controle da poluição para o interior das plantas industriais e desencadeou um importante processo de melhoria do desempenho ambiental das indústrias. O processo teve uma intensa presença da Central de Tratamento de Efluentes Líquidos - CETREL, na coordenação. Os avanços inicialmente voltaram-se para o aprimoramento dos sistemas de pré-tratamento, coleta, tratamento e disposição final. Mais recentemente, várias empresas iniciaram esforços para minimizar e até eliminar os resíduos no próprio processo produtivo. Esses esforços de Prevenção da Poluição têm sido basicamente desenvolvidos no interior de cada empresa, de forma isolada. Quase que exatamente dez anos depois, essa visão se consolida na resolução $n^{\circ} 2.113$, de 22/10/1999, do atual Conselho Estadual de Meio Ambiente.

Não se tem conhecimento, contudo, de iniciativas de articulação entre as empresas de forma a otimizar-se o desempenho ambiental do conjunto com medidas preventivas e não apenas de fim-de-tubo. Colocado de outra forma, poder-se-ia se dizer que se, por um lado, estão sendo iniciadas atividades de Produção Limpa, por outro, não se está implementando o conceito da Ecologia Industrial. Dessa maneira, pode-se estar deixando de lado oportunidades adicionais que possam desembocar em soluções de menor impacto ambiental e menor custo. 
Outro importante ecossistema industrial brasileiro foi avaliado por Fragomeni (2005) e as suas principais conclusões foram como segue: "O Programa Rio Ecopolo foi uma iniciativa ousada e inovadora no sentido de implantar e estimular a operacionalização de Parques Industriais Ecológicos no Estado do Rio de Janeiro. Foi particularmente importante para os Ecopolos do Distrito Industrial de Santa Cruz e do Distrito Industrial da Fazenda Botafogo, pois foi através do Programa que um processo sistemático de maior integração foi iniciado ...e ... as associações de indústrias locais, AEDIN e ASDIN, vêm se mostrando como importantes agentes articuladores no sentido de manter uma constante troca de informações, o que é fundamental para formação de uma base de dados consistente, que viabilize o delineamento de projetos conjuntos pelas empresas... Em relação ao Pólo Petroquímico de Campos Elíseos, em Duque de Caxias, este é o que vem mais efetivamente se configurando como um Parque Industrial Ecológico, tanto por apresentar características de simbiose industrial entre as empresas deste complexo (ex: REDUC-Rio Polímeros; Rio Polímeros-Polibrasil; AGA-Rio Polímeros) quanto por apresentar relevantes projetos de gestão compartilhada".

Para melhoria do parque formado no Rio de Janeiro, Fragomeni (2005) sugere "que a liderança deste processo seja conduzida por entidades de representação industrial, ao invés do governo. As associações de indústrias locais continuariam auxiliando o processo de articulação das empresas em cada Ecopolo. Por sua vez, as associações seriam coordenadas pela federação de indústrias estadual, ou seja, no caso do Rio, pela FIRJAN... dando visibilidade ao instrumento e às indústrias participantes dos mesmos, até as diretrizes básicas para o fomento de práticas comuns aos Ecopolos, como por exemplo, sugerindo modelos comuns de formulários a serem adotados para o estabelecimento de inventários, ou fornecendo propostas de indicadores ambientais a serem utilizados para avaliar o desempenho do complexo industrial, ou subsidiando modelos de relatório para sistematização e registro dos resultados dos projetos conjuntos desenvolvidos, entre outras possíveis ferramentas... Ressalta-se aqui que é imprescindível o reconhecimento por parte das indústrias participantes de que os Parques Industriais Ecológicos consistem em um instrumento capaz de proporcionar oportunidades de negócios ambientais, econômicos e sociais, sendo esta definitivamente a chave para garantir o sucesso, solidez e longevidade dos mesmos..." O envolvimento 
do governo neste processo é certamente muito importante, podendo se dar, "por exemplo, através da incorporação de diretrizes sobre o assunto nas políticas públicas, reforçando sua relevância perante as indústrias. Adicionalmente, entende-se que o governo deve atuar fortemente na fase de planejamento dos parques industriais, tanto daqueles em fase embrionária como daqueles em vias de expansão, em função da sua capacidade de fomentar e influenciar o recrutamento de indústrias, auxiliando a formação da configuração industrial mais desejada."

\subsubsection{Avaliação do Ciclo de Vida}

Como comentado anteriormente, o metabolismo ambiental é um conceito estreitamente ligado ao conceito de Ecologia Industrial. Este conceito pressupõe um bom controle de materiais e energia em qualquer sistema sob estudo, o que apresenta similaridade importante com a metodologia de Avaliação do ciclo de vida (ACV ou LCA - Life-Cycle Assessment). Muito embora não se tenha encontrado informação da aplicação do conceito de metabolismo industrial a um sistema pelo uso de software, para AVC é comum o uso de sistemas de controle de processo (STOBBE, 2001), por exemplo SAP (Enterprise Resource Planning), especialmente para eletroeletrônicos (HENDRICKSON, 2001). Assim, especial ênfase foi dada à ACV neste capítulo.

ACV é uma metodologia que facilita a comparação, quanto ao impacto ambiental, entre atividades, serviços ou produtos no período de suas existências. Por tratar-se de metodologia científica, ou seja que pode ser repetida e confirmada, possibilita a escolha do mínimo impacto ambiental entre duas ou mais opções. Na definição da SETAC (Society of Environmental Toxicology and Chemistry) "a avaliação do ciclo de vida é o processo objetivo de avaliar as cargas ambientais associadas com um produto, processo ou atividade através da identificação e quantificação do uso de energia e matéria e de emissões ambientais, o impacto do uso da energia e material e das emissões, e a determinação de oportunidades de melhorias ambientais. A avaliação inclui todo o ciclo de vida do produto, processo ou atividade, envolvendo extração e processamento de matérias-primas; fabricação, transporte, e distribuição; uso/reuso/manutenção; reciclagem; e disposição final". Uma definição abrangente e complexa como esta possui 
diferentes interpretações, no entanto todas reconhecem três estágios no desenvolvimento da avaliação do ciclo de vida: inventário, análise do impacto e melhoria ou ganho ambiental. "Podemos também considerar os limites ou escopo da avaliação como um estágio" (SETAC, 1993). Limite ou escopo da avaliação é a definição e proposta do estudo, a determinação da unidade funcional considerada e os procedimentos que assegurem a qualidade dos resultados. "Talvez, não haja momento mais crítico no início de uma avaliação do ciclo de vida do que definir precisamente o escopo da análise" Graedel e Allenby recomendam, como regra geral, que a profundidade da análise deve estar vinculada ao grau de liberdade que se dispõe para escolher opções, e a importância dos aspectos ambientais e tecnológicos que levam à avaliação. (GRAEDEL e ALLENBY, 1995). Assim, têm-se as seguintes etapas:

a) O inventário no estudo do ciclo de vida (LCI Life-Cicle Inventory) busca quantificar necessidades de energia e matéria-prima, resíduos sólidos líquidos e gasosos, e outros danos ou perdas quantificáveis durante a vida de um produto, embalagem, processo, material ou atividade. É uma metodologia que vem sendo aplicada desde o início dos anos 60, com enfoque no consumo de energia, sendo o mais conhecido e desenvolvido dos estágios na avaliação do ciclo de vida.

b) "A análise do impacto é um processo sistemático de identificar, caracterizar, e valorar potenciais impactos ao ecossistema, saúde humana e recursos naturais associados às entradas e saídas de um produto ou processo" (EPA, 1993b). Avalia o significado dos resultados do inventário, fazendo uma relação qualitativa das longas tabelas elaboradas no estágio anterior. Apesar de não haver uma metodologia de consenso geral, executa três passos: classificação, caracterização e valoração. Com a classificação determina-se a que categoria de impacto será creditada as entradas e saídas definidas pelo inventário. Exemplificando: emissões gasosas podem ser consideradas como perturbadoras da camada de ozônio ou classificadas como causadoras de chuva ácida. Podendo também, um único poluente ser classificado em mais de uma categoria, como os NOx que podem causar acidificação e também participar na formação da neblina fotoquímica. A caracterização é o processo de agregar e quantificar impactos dentro das categorias determinadas na classificação. Utilizando novamente o exemplo de emissões gasosas, nesta fase vários gases que 
contribuam para o efeito estufa seriam agregados e expressos em $\mathrm{CO}_{2}$ equivalentes, a unidade mais freqüente e conhecida. A valoração é uma forma subjetiva de comparar as diferentes categorias de impacto, pois está vinculada a valores culturais, políticos e/ou éticos. Sua escala de importância está intimamente ligada às necessidades imediatas de um local ou povo, e seus valores. Como exemplo tem-se as diferentes formas de considerar a saúde do trabalho nos vários países, ou a menor importância que é dada, pelos países carentes de desenvolvimento, à poluição devido à necessidade mais urgente de resolver problemas como a fome.

c) A melhoria ou ganho ambiental pode ocorrer quando se tem identificados e avaliados os impactos ambientais passíveis de melhoria. Apesar da inexistência de uma metodologia definida, a melhoria ambiental tem ocorrido, quase sempre, quando uma tentativa de avaliação do ciclo de vida é efetuada. A realização do inventário, como foi descrito, já é o suficiente para que sejam levantados processos ou características de um produto que possam ser modificados para um ganho ambiental, mesmo sem a realização da análise de impacto (HABICHT apud EPA, 1993a). Até 1996 - ano da primeira versão da ISO14001, segundo Reis (1996), membro da delegação brasileira junto ao TC-207 da ISO, o estado da arte dos documentos sobre a avaliação do ciclo de vida correspondia a: "Limites ou escopo" e "Inventário" encontravam-se definidos e documentados, contudo "Avaliação do impacto" encontrava-se apenas conceitualmente definida e a "Melhoria Ambiental" não se encontrava documentada, o que pode explicar o atraso do desenvolvimento da metodologia.

Para Graedel e Allenby (1995) as conclusões tiradas dos estágios de inventário e análise do impacto da avaliação do ciclo de vida, quando implementadas, tornam-se design for environment (DFE). O design pode ser de produtos ou processos e geralmente é desenvolvido por pessoas diferentes nos dois casos. "Processos são mais universais que produtos, e suas alterações são difíceis e caras, pelo menos a curto prazo". Designers de produto, em contraste, têm considerável flexibilidade quando escolhem os processos necessários aos seus produtos.

A sigla DFE origina-se do sistema DFX (Design for $X$ ) em que $X$ representa a característica de um produto que deva ser maximizada, como facilidade de montagem, 
manutenção etc. Como não existe uma fórmula pronta do que seja ecologicamente correto, o que se deseja do projetista é que este antecipe os impactos ambientais de um produto no seu ciclo de vida e tenha como meta eliminação de desperdícios e escolha de materiais apropriados. Isso pode ser obtido com um inventário ambiental do produto, em uma matriz de avaliação do ciclo de vida, como exemplificado na Tabela 1.2. Como a ACV tem como objetivo comparar produtos, o escopo pode ser definido como apenas algumas etapas, não necessariamente partindo-se da extração das matérias-primas. A dificuldade para o preenchimento da matriz da Tabela 1.2 é a comparação e valoração de parâmetros diferentes. Por exemplo, questões como a opção entre utilização de matériaprima virgem ou reciclada esbarra em consumos diferentes de energia para cada um dos casos. Para Horst e Zweers (1993) “quando todas estas variáveis são estudadas, nenhuma delas parece fornecer a resposta definitiva e seu sucesso depende da situação em que são aplicadas". Assim, melhores resultados poderiam ser obtidos considerando a matriz da Tabela 1.2 como uma referência para busca da melhoria contínua da performance ambiental de um produto, em lugar de atribuir valores absolutos na avaliação. "A valoração ou avaliação não indica melhorias ambientais, mas revela onde as melhorias podem ser feitas"(ALTING e JORGENSEN, 1993). Deste modo, o projeto de um novo produto ou readaptação dos produtos já existentes deve ter como alvo primário o uso mínimo e apropriado de materiais, projetos robustos com longa vida útil e projetar para o desmonte, reutilização e reciclagem.

Tabela 1.2 Matriz da ACV (GRAEDEL e ALLENBY, 1995)

\begin{tabular}{|l|l|l|l|l|l|}
\hline Estágio & Materiais & Energia & .sólido & r.líquido & r.gasoso \\
\hline Extração & & & & & \\
\hline Produção & & & & & \\
\hline Distribuição & & & & & \\
\hline Uso & & & & & \\
\hline Reciclagem/descarte & & & & & \\
\hline
\end{tabular}

Segundo Bakker (1993) "o uso de uma avaliação quantitativa do ciclo de vida para produtos tecnicamente complexos é difícil. Mas, se a informação ecológica é bem estruturada, bem apresentada, com conteúdo e acessível, então será usada pelos projetistas". Uma conseqüência da aplicação do DFE, considerando a avaliação do ciclo de vida é projeto para o desmonte, DFD (Design for Disassembly), ou para a reciclagem 
DFR. Assim, o objetivo primeiro deve ser obter materiais ou componentes aptos a serem reciclados e fazer esta recuperação com a menor degradação possível, ou seja, evitando que sejam perdidas a utilidade e energia já agregadas ao produto. Portanto, as prioridades para a reciclagem são: redução de materiais; reutilização de componentes; remanufatura; reciclagem de materiais; geração de energia (combustão); disposição em aterros, em último caso.

Tanto a reutilização de componentes, a remanufatura, como a reciclagem de materiais dependem grandemente da possibilidade de desmonte do produto eliminando a contaminação entre diferentes tipos de materiais, fator decisivo na reciclagem, e o reaproveitamento de componentes nos mais altos níveis de energia e trabalho incorporados. O projeto do produto deve prever a facilidade de desmonte como forma de viabilizar a reciclagem e a reutilização. Atualmente, a reciclagem é normalmente usada para materiais plásticos, metais ferrosos e poucos metais não-ferrosos, que têm elevado custo de obtenção. Ao contrário dos materiais plásticos, a reciclagem dos metais pode ser realizada indefinidamente e sem perda de categoria. Para os metais descartados o processo de reciclagem normalmente utiliza o retalhamento do produto descartado seguido de várias classificações e separação magnética após a retirada da parte leve, como plásticos e têxteis. Permanecem sem separação principalmente materiais não magnéticos como o vidro, borracha e alguns plásticos que terão como destino a incineração ou aterros sanitários. Contudo, a forma correta de preparar produtos para a reciclagem deveria considerar: drenagem de fluidos; desmontagem antes do retalhamento; retalhamento e classificação do restante. Daí a importância do Projeto para Desmonte ou DFD.

O chamado Projeto para Desmonte, ou DFD, é condição necessária para que os produtos possam ser economicamente recicláveis. O DFD nasceu da pressão nos países industrializados sobre os fabricantes no sentido de torná-los co-responsáveis com o final de vida de seus produtos, devido à saturação dos aterros sanitários e locais de disposição. Tão grande é esta pressão, que autores como Tipnis (1994) questionaram se produtos deveriam ser vendidos ou alugados (leased). Exemplo desta proposta é a Xerox Corp. (HARLAN, 1998), que recicla cerca de um milhão de partes de seus equipamentos por ano com destino a peças de reposição e aparelhos novos e que resulta numa economia de 
200 milhões de dólares anuais. Para avançar nesta tendência seus engenheiros trabalham reduzindo o número de componentes e aumentando os produtos com componentes comuns.

O DFD influencia de forma decisiva a reciclagem e a facilidade de desmonte, torna possível a reutilização e a remanufatura de forma mais eficiente, prolongando a vida útil dos produtos ou de seus componentes, tornando mais fácil também a manutenção. Muitos produtos são abandonados quando necessitam de reparos em apenas um de seus componentes, devido a dificuldades de diagnóstico da falha e/ou desmontagem. Os benefícios mais evidentes do DFD são: componentes de maior importância podem ser recuperados; melhor separação dos metais, agora sem contaminação; partes desmontáveis de não metálicos podem ser reprocessadas.

Atualmente o desmonte se inviabiliza economicamente por não ser levado em consideração nas fases iniciais do projeto, o que resulta em alto custo de mão-de-obra. $\mathrm{Na}$ concepção do produto, mudanças podem ser feitas com um baixo custo. Faltam também estímulos aos fabricantes para adotarem medidas visando o desmonte que facilite a reciclagem e a reutilização de componentes, após o uso do produto.

\subsection{ACV Simplificado}

Como o conceito de ciclo de vida pressupõe uma forma holística de avaliar os impactos ambientais de um produto ou sistema do berço ao túmulo, e já que a dificuldade de sua implementação está numa completa avaliação quantitativa das entradas e saídas, nos diferentes estágios, "uma forma de ACV simplificada pode ser mais prática para a rotulagem ambiental" (EPA, 1993b). Ou, "qualquer metodologia, se aplicável a seleção de materiais, processos, componentes, ou produtos complexos, é freqüentemente mais efetiva se qualitativa, não quantitativa" (ALLENBY e GRAEDEL,1995). Vários exemplos de simplificação da $\mathrm{ACV}$, destinados a rotulagem de produtos ou não, 
justificam-se pela real aplicação. Um exemplo bem sucedido desta simplificação é o do Centro para Produtos e Tecnologias Limpas da Universidade do Tennesse-USA que desenvolveu um processo analítico hierárquico (AHP - Analytical Hierarquical Process). Através de um questionário são consultados experts da área acadêmica, industrial e governamental, para uma série de comparações entre dois produtos, no caso sacos de papel kraft e de polietileno.

O questionário divide o ciclo de vida de cada produto em quatro estágios: extração de matéria-prima, produção de intermediários, fabricação e transporte, uso e disposição final. As respostas foram solicitadas a definir a relativa importância das categorias de impacto para cada estágio do ciclo de vida dos dois produtos (Tabela 1.3). O resultado tabelado deixa evidente que a produção de intermediários, para os dois produtos, é o estágio do ciclo de vida mais determinante em quase todas as categorias de impacto. A partir destas conclusões pode-se fazer um inventário quantitativo dos dois produtos somente na produção de intermediários, ou fixar parâmetros para uma certificação ambiental de produtos mais eficaz.

Outro exemplo de avaliação do ciclo de vida simplificada é o Singapore Green Label que ao invés de examinar cada impacto do produto no meio ambiente, isola e estuda poucos, porém importantes, parâmetros de cada categoria de produtos. Como no caso de baterias de zinco-carbono, o critério de aferição da logomarca está condicionada unicamente ao seu conteúdo de mercúrio (<10 ppm Hg) (Singapore Green Label). Outro bom exemplo é o do selo alemão Blue Angel que utiliza uma matriz com enfoque qualitativo para selecionar os mais importantes estágios do ciclo de vida e os parâmetros de entradas e saídas para a certificação. De qualquer maneira, a obtenção do inventário de ciclo de vida, de modo simplificado ou não, é fundamental para a aplicação do ACV.

Tabela 1.3 Questionário para AHP (EPA,1993b) papel kraft e polietileno

\begin{tabular}{|c|c|c|c|c|}
\hline Estágio ACV & extração & intermediários & fabricação & transporte/uso/final \\
\hline Ácidos & & $\square \mathbf{\square}$ & & \\
\hline Ef.estufa & & $\mathbf{\square}$ & & $\square \mathbf{\square}$ \\
\hline Ozônio & & $\square$ & & $\square$ \\
\hline Fumaça & & $\square \square$ & & \\
\hline Ar/danos & & $\square \mathbf{a}$ & & $\square$ \\
\hline Ar/partículas & & $\mathbf{a}$ & & $\square$ \\
\hline Ar/outros & $\square$ & $\square \mathbf{\square}$ & & $\square$ \\
\hline
\end{tabular}




\begin{tabular}{|c|c|c|c|c|}
\hline Água/danos & & $\square \mathbf{q}$ & & \\
\hline Água/O2 & & $\square \mathbf{q}$ & & \\
\hline Água/outros & & $\square \mathbf{q}$ & & \\
\hline Sólido/danos & & $\square \mathbf{\square}$ & & \\
\hline Sólido/outros & $\square$ & $\square$ & & $\square$ \\
\hline Energia/uso & $\square$ & $\square \mathbf{\square}$ & & \\
\hline
\end{tabular}
= pouca ou nenhuma importância; $\square$ = média importância; - $\mathbf{\square}$ = alta importância

\subsection{Inventário do Ciclo de Vida}

O primeiro estágio em um ACV é o inventário do ciclo de vida (LCI) dos recursos usados e das emissões causadas por certo produto. Entretanto, problemas persistem com os registros incertos devido a inconsistência de dados, levando em conta que os materiais devem ter todo seu ciclo de vida registrado, para cada componente. ACV analisa o impacto ambiental de todos os produtos e processos, o que exige a compilação de muito dados e, portanto, requer um sistema de base de dados, sistemas de trocas de informações e um modelo matemático para cálculos de aplicações em potencial. Baseando-se na avaliação ambiental melhorias podem, então, ser feitas para os processos e produtos minimizando o impacto ao meio ambiente.

De acordo com a proposta da ISO (1997), os dados requeridos, pelo inventário do ciclo de vida, com as unidades correspondentes estão listados na Tabela 1.4. Um problema típico na obtenção de dados para o inventário do ciclo de vida está na localização das informações durante as diferentes etapas de processo, pois estas estão disponíveis em diferentes estruturas organizacionais. As estruturas organizacionais e as respectivas entradas estão listadas na Tabela 1.5. Suprimentos e lubrificantes são normalmente reportados por centros de custo, mas também podem ser administrados por fábricas. Estes problemas de segmentação da responsabilidade dos insumos dificultam o levantamento dos dados. A avaliação de impacto inclui a toxicidade, potencial de alerta global, potencial de impacto na camada de ozônio, potencial eutrópico entre outros.

Tabela 1.4 - Dados requeridos para o inventário do ciclo de vida

\begin{tabular}{|l|l|}
\hline Entrada & Unidades \\
\hline Material / Substância & Peso \\
\hline Eletricidade & Watts \\
\hline
\end{tabular}




\begin{tabular}{|l|l|}
\hline Gases & Volume \\
\hline Solventes & Volume \\
\hline Água & Volume \\
\hline Saída & Unidades \\
\hline Produtos & Peso \\
\hline Saída de materiais recicláveis & Peso \\
\hline Resíduos Sólidos & Peso \\
\hline Emissão de gases & Concentração \\
\hline Emissão de fluídos & Concentração \\
\hline Água descartada & Volume \\
\hline
\end{tabular}

Tabela 1.5 - Dados relacionados com as estruturas organizacionais

\begin{tabular}{|l|l|}
\hline Estrutura Organizacional & Saída de dados \\
\hline Fábrica & Resíduos \\
& Água \\
\hline Centro de Custo & Suprimentos \\
& Lubrificantes \\
\hline Escritório & Calor \\
& Luz \\
& Ar condicionado \\
& Eletricidade \\
& Água \\
& Ar Comprimido \\
& Emissões \\
\hline Equipamentos & Eletricidade \\
\hline Produtos & Materiais \\
\hline
\end{tabular}

Portanto, as tendências apontam, como as normas ISO 14000 e os atores ambientais da agência ambiental americana (EPA), para a prevenção da poluição e o estudo do ciclo de vida do produto como condição para rotulagem ecológica, "numa abordagem que já foi chamada de berço-túmulo para tornar-se berço-reencarnação" (GRAEDEL e ALLENBY, 1995).

\subsection{Software para Controle de Processo}

A informática está presente hoje nas mais diversas áreas das empresas e estas dificilmente sobrevivem sem a utilização da tecnologia e de sistemas de informação. Os desafios de uma economia globalizada e altamente competitiva requerem sistemas de informação que assegurem agilidade e confiabilidade às tomadas de decisão e à operacionalização dos negócios. O uso crescente de sistemas e equipamentos de informática nas empresas originou o termo Tecnologia da Informação. $O$ termo Tecnologia de Informação (TI) muitas vezes é confundido ou tem-se como sinônimo de 
Sistema de Informação. Segundo Alter (1996), a TI vem a ser um conjunto de hardwares e softwares que possibilitam a geração, armazenamento, veiculação, processamento e reprodução dos Sistemas de Informação.

Para Beuren (1998), tecnologia de informação corresponde ao conjunto de componentes necessários para o tratamento das informações, como hardware (equipamento), software (programa ou conjunto de programas), telecomunicações, redes e outros meios disponíveis. A questão da TI envolve tanto aspectos técnicos como organizacionais, que incluem recursos humanos, negócios e metas e, principalmente, uma postura administrativa ampla e bem elaborada.

Cada vez mais é aceita a idéia de que o verdadeiro patrimônio de uma entidade é a sua tecnologia, que compõe seus sistemas, processos e informações. Instituições financeiras caminham para dispêndios da ordem de 5\% em computação em relação a sua receita operacional e um sem-número de entidades seguem patamares superiores a $2 \%$ com informatização versus faturamento (GIL, 1999).

A utilização de sistemas aplicativos, como suporte a negócios, requer ainda a utilização e tecnologia sofisticada, envolvendo interfaces com diferentes sistemas, transações que atualizam arquivos em "real-time", transferência eletrônica de dados com clientes, fornecedores e instituições financeiras. Atender a normas e legislação complexa, variada e alterada com freqüência, também são exigências comuns dos sistemas. Surgem aí novas técnicas de controle, para assegurar a integridade dos dados que trafegam pelos sistemas. Portanto, um sistema de informação designa a logística indispensável para a realização do processo de informação, não se reduzindo somente à informática.

O sistema de informação, composto de vários módulos que integram fortemente as áreas financeira, industrial, comercial, administrativa e contábil da empresa e que tem tratamento das informações indispensáveis à gestão das rotinas e das mudanças aceleradas no ambiente empresarial, é conhecido comercialmente como Enterprise Resource Planning (ERP) e a sua característica principal é a parametrização do fluxo de trabalho, onde os usuários conseguem fazer ajustes de forma rápida e sem perder o controle ou a perspectiva histórica das atividades (WOOD e CALDAS, 2000). Para a implantação de um sistema ERP ou Sistema de Gestão Empresarial, as empresas devem considerar alguns tópicos (AMOR, 2000): a) Processos de negócio: o sistema deve 
suportar todos os processos do negócio; b) Integração de componente: o sistema deve ser altamente integrável entre as rotinas; c) Flexibilidade: deve ser ajustável às necessidades da empresa; d) Conectividade com a Internet: deve estar integrado aos negócios on-line da empresa; e) Implementação rápida: reduzindo a espera do retorno sobre o investimento; f) Facilidade de uso: gerenciado por todas as pessoas da empresa, em diversos níveis. Existem, no mercado, diversos ERPs ou Sistemas de Gestão Empresarial, possuindo características específicas que os direcionam a determinados tipos e portes de empresa. Um dos pontos que influencia na hora da escolha de um ERP é o tamanho da organização. Por exemplo, o sistema SAP/R3 está nitidamente voltado para as grandes empresas e o sistema People Soft está voltado para as médias empresas.

\subsubsection{Sistemas Enterprise Resource Planning}

Os sistemas ERP's e seus fornecedores começaram sua história há mais de 40 anos. Os principais fornecedores de softwares ERP no mercado atual, segundo Norris et al. (2000) e Kishore (2002), são apresentados a seguir.

- $\underline{\text { SAP: }}$ a precursora do ERP, fundada em 1972 por 5 engenheiros da IBM, é a maior do grupo. O seu software é conhecido como R/3 e é designado para ajudar a organizar o processo de manufatura e contabilização. SAP também oferece módulos de logística e recursos humanos. Recentemente, SAP expandiu sua linha de produtos incluindo SCM (Supply Chain Management), automação da força de vendas e datawarehouse.

- PeopleSoft: considerado o fornecedor número dois do ERP. PeopleSoft fez sua marca com o software de recursos humanos. A empresa atualmente direciona seu foco ao setor de serviços com produtos designados a ajudar empresas a gerenciar seus custos intangíveis.

- Oracle: tem vendido aplicativos ERPs para trabalhar com seu banco de dados desde 1987. Oracle vende a maioria de seus aplicativos para fabricantes e consumidores de produtos de consumo, fazendo uma competição direta com a SAP. Oracle vivenciou alguns problemas, no passado, devido à reorganização da sua força de vendas e também incertezas por parte dos clientes com o lançamento da versão 11.0. 
- Baan: é uma empresa holandesa, com quase 20 anos no mercado, que vende software para empresas cautelosas com o sistema da SAP. Recentemente, como outros grandes vendedores, eles vêm suprindo pequenos provedores de software, o que tem resultado numa vasta variedade de produtos oferecidos no mercado.

- J. D. Edwards: embora eles tenham vendido software por décadas, eles vieram a público há pouco tempo. Desde que lançaram seu produto, um sistema ERP mundialmente aberto, eles se tornaram competidores por uma fatia de mercado juntamente com os 4 maiores.

No mercado das grandes empresas, SAP e PeopleSoft têm tido um sucesso contínuo no mercado, devido ao fato de oferecerem mais características a seus clientes atuais e também, consistentemente, terem atraído grande variedade de novos clientes. A Figura 1.1 ilustra o mercado disputado pelas maiores empresas de sistemas de gestão, além de mostrar o aparecimento de outros fornecedores que, embora com uma faixa de mercado menor, também disputam o mercado de ERP (KISHORA, 2000).

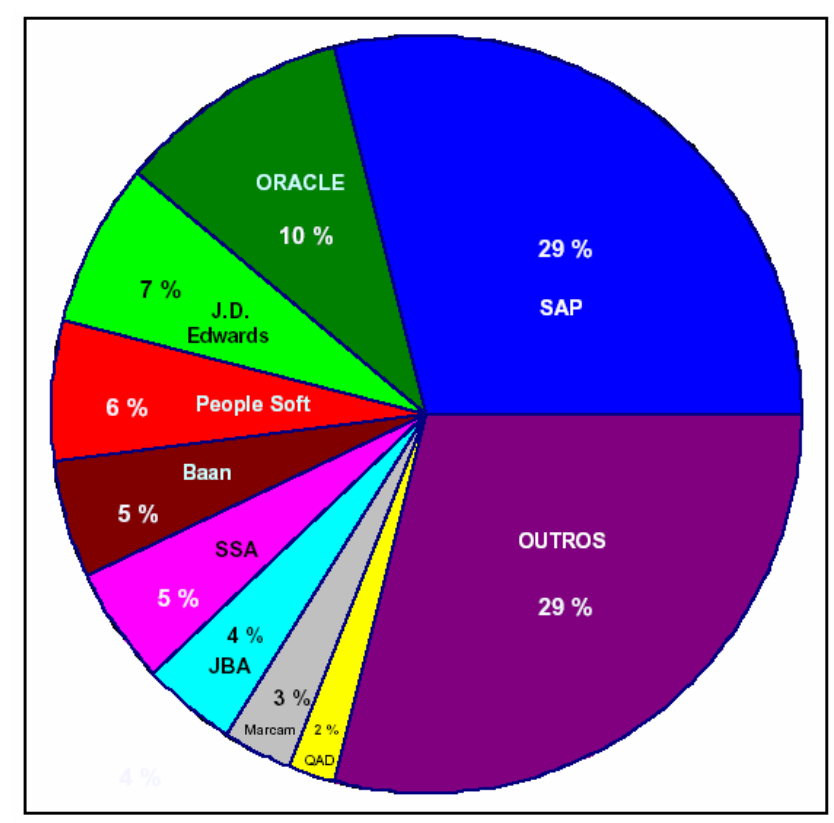

Figura 1.1 Distribuição do mercado de ERP, adaptado de Kishora 2000 pág. 200.

As 5 maiores companhias, exemplificadas na Figura 1.1, dominam quase $60 \%$ do mercado mundial de softwares ERP, o que é uma grande fatia dos quase US\$ 7 bilhões 
deste segmento industrial. A líder é a SAP, com quase $30 \%$ do mercado, portanto o programa R/3 da SAP foi selecionado como ponto de partida e referência para obtenção de dados deste trabalho. Por fim, observe-se que, com a evolução da internet, empresas desenvolvedoras desse tipo de sistema tiveram que adaptá-lo às exigências do mercado, pois essa conectividade permite o auto-atendimento. Com isso, os clientes e fornecedores interagem com as empresas, sem a necessidade de contato com um representante.

Um sistema ERP é um gigantesco sistema empresarial que contempla as operações de empresas inteiras, o que permite às corporações gerenciar a função crítica dos seus negócios, mas também significa alto custo. Um software de gestão consiste na informatização e integração de todas as operações internas da empresa que envolve a parte operacional - compras, vendas e prestação de serviços - visando racionalizar os processos de trabalho, eliminando tarefas redundantes, circulação física de documentos, dados e informações. Porém, uma empresa grande pode chegar a gastar US\$ 30 milhões por vários anos para implantar um gigantesco sistema que permita gerenciar e monitorar níveis de inventários, serviços a clientes, dados operacionais/financeiros, e recursos humanos (KISHORE, 2002). Deste modo, os sistemas de ERP citados são utilizados por grandes e médias empresas, devido ao seu custo de implantação e manutenção. As pequenas empresas que optam pela informatização de seus processos normalmente usam sistemas desenvolvidos sob encomenda com linguagens de programação variadas (JAVA, SQL, Delphi).

As principais características dos sistemas de ERP's segundo diferentes autores são mostradas na Figura 1.2. Como demonstra a Figura, os ERP's fazem a interface entre os clientes e fornecedores da empresa, com controle de estoques, compras e vendas em uma base de dados única, com o principal objetivo de impedir dados incoerentes e/ou duplicados. É relevante observar a integração de todas as áreas da empresa pelo suporte necessário para as informações requeridas em cada setor. Para as empresas, a utilização deste software permite um gerenciamento melhor de seus negócios, por meio da integração e consolidação dos dados, pois automatiza atividades como controle de estoque, controle de caixa, contabilidade, contas a pagar/receber, suprimento de mercadorias, análise de margens de lucro e dá apoio a programas de marketing, como gestão de categoria de produtos, levantamento de resultados de campanhas de vendas e 
definição do perfil da clientela como, por exemplo, as preferências e freqüências de compras. Para realizarem estas tarefas, as pessoas precisam estar preparadas, o que mostra a necessidade de treinamento constante, pois o conhecimento de sistemas de informação da empresa consiste em três elementos (LAUDON, 1999): “Um conhecimento e uma habilidade prática com tecnologias de informação. Uma compreensão ampla de organizações e indivíduos, com uma perspectiva comportamental e compreensão ampla de como analisar e resolver problemas". Outras funcionalidades não são características citadas por todos os autores como o suporte ao planejamento estratégico e a tomada de decisão, isto porque estas características dependem de customização do sistema e atuação pró-ativa do corpo tático e estratégico da empresa.

Um exemplo mais restrito (HOSS, 2000) de uso de um software de gestão comercial, envolvendo algumas atividades básicas como compras e vendas, é mostrado na Figura 1.3, através do Diagrama de Fluxo de Dados. Neste caso, o software pode proporcionar um melhor atendimento a clientes, reduzindo tempo de pagamento (por exemplo em filas), benefícios como a exibição clara e correta de preços e condições de pagamento, segurança e rapidez na liberação de notas fiscais, tudo respeitando a legislação pertinente. 


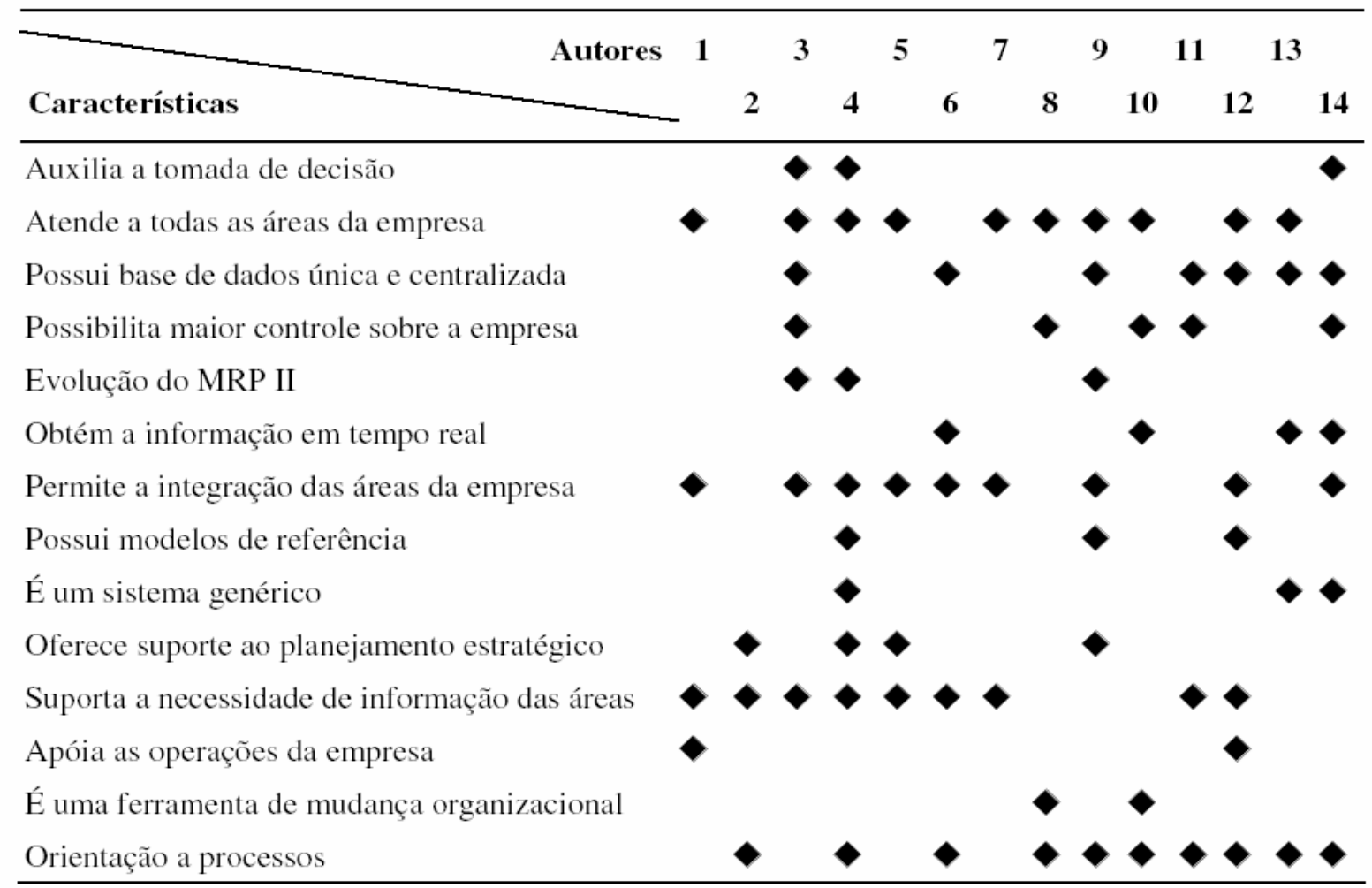

Legenda:

\begin{tabular}{|c|c|c|}
\hline 1 - Buckhout et al. (1999) & 6 - Deloitte Consulting (1998) & 11 - Miltello (1999) \\
\hline 2 - Centola \& Zabeu (1999) & 7 - Dempsey (1999) & 12 - Souza \& Zwicker (2000) \\
\hline 3 - Corrêa et al. (1997) & 8 - Informática Exame (1997) & 13 - Stamford (2000) \\
\hline 4 - Cunha (1998) & 9 - Hehn (1999) & 14 -Wood Jr. (1999) \\
\hline 5 - Davenport (1998) & 10 - Lima et al. (2000) & \\
\hline
\end{tabular}

Figura 1.2 Principais características dos ERP's segundo diferentes autores 


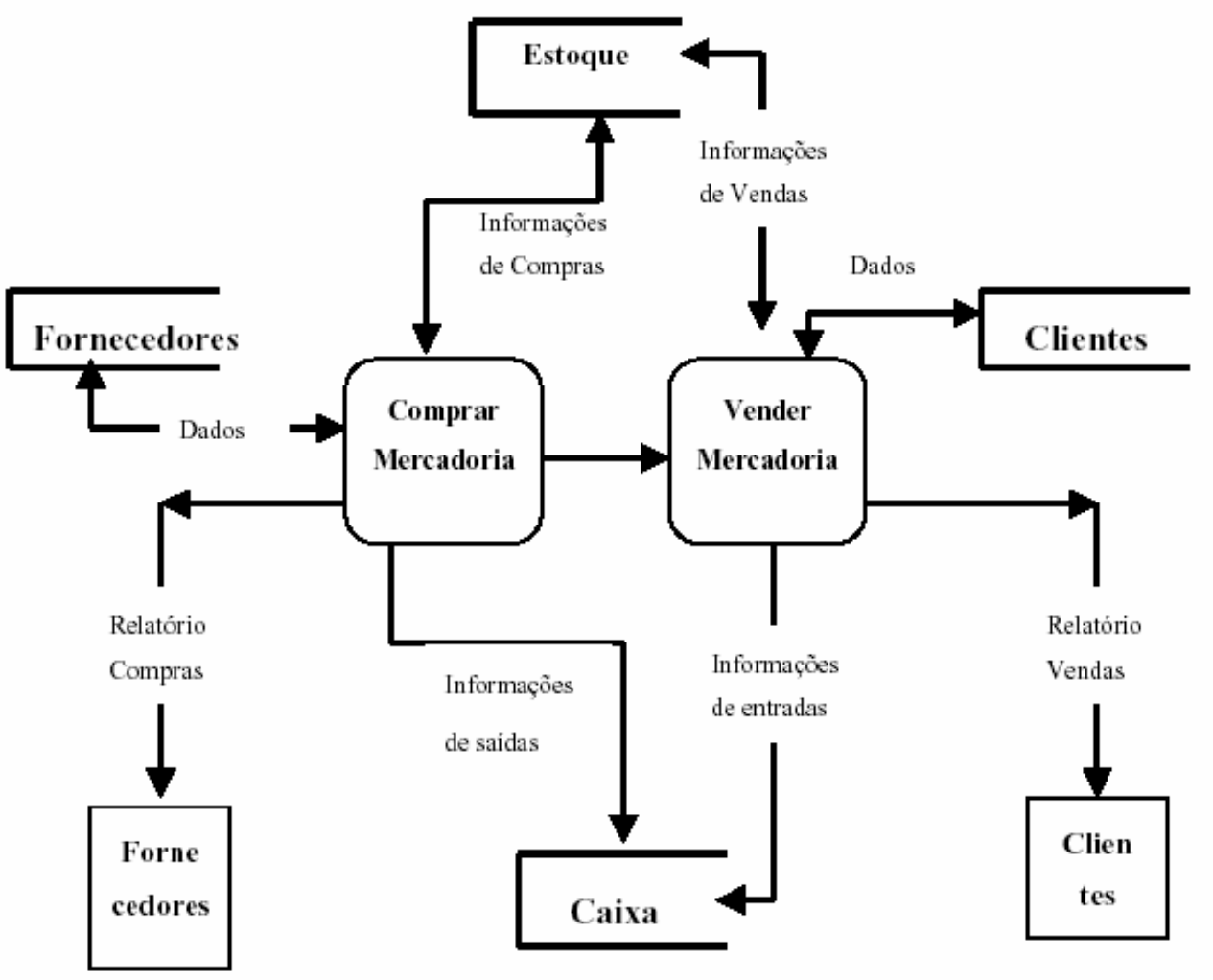

Figura 1.3 Diagrama de Fluxo de Dados Softwares de Gestão adaptado Hoss 2000 página 100

\subsubsection{Sistemas de Apoio à Decisão}

A tomada de decisão é um processo realizado pelos seres humanos a partir das informações oferecidas pelo software. Quanto melhores forem as informações, melhores serão as decisões, como colocam Hammond et al. (1999), "melhores informações significam melhores decisões. Quando existem incertezas afetando a decisão, é útil gerar alternativas para se obter as informações necessárias para reduzir as incertezas.” Portanto, para o autor, a confiabilidade nas informações é fundamental para a tomada de decisão. $\mathrm{O}$ tomador de decisão deve ser uma pessoa treinada em termos da tomada de decisão e deve estar comprometido com o sistema como ferramenta de apoio à sua tarefa de tomar decisões. A aplicação das decisões é a etapa final do processo. Entretanto, a efetiva melhoria do desempenho organizacional é decorrência de uma abordagem estratégica de 
todo o processo. Isto é, haverá melhoria do desempenho se todo o processo, desde o apontamento de dados até a aplicação da decisão, for melhor que o processo da concorrência. Para dar suporte à tomada de decisão existem sistemas específicos que sumariam as informações dos ERP's e de outros sistemas, de forma gráfica e em real time, estes softwares são denominados Datawarehouses (DW).

As aplicações de Sistemas de Banco de Dados podem ser classificadas em sistemas de processamento on-line de transações (OLTP) e sistemas de suporte à decisão, incluindo processamento analítico on-line (OLAP).

Os sistemas de processamento de transações são muito comuns nas empresas, uma vez que lidam com informações compostas pelo nome e identificador, e geram grande volume de dados que precisam ser armazenados. A tecnologia de bancos de dados, isoladamente, atende às aplicações de processamento de transações. Já os Sistemas de Apoio à Decisão são interativos e têm como principal objetivo ajudar as pessoas com poder de decisão em um negócio, seus usuários finais, a utilizarem dados e modelos para identificar e resolver problemas, assim como definir resoluções. Os grandes bancos de dados resultantes dos sistemas de processamento de transações são verdadeiras fontes de informações para o processo decisório, embora alguns pontos importantes da recuperação de dados para aplicações de suporte à decisão mostrem que a tecnologia dos bancos de dados, isoladamente, não é adequada às suas necessidades específicas. Vários aspectos podem ser mencionados, dentre eles:

a) algumas consultas de suporte à decisão não podem ser expressas ou não são facilmente expressas em Structured Query Language (SQL);

b) empresas de grande porte possuem diversas fontes de dados armazenados sob diferentes esquemas, e, muitas vezes, partes da empresa não têm acesso a elas por questões de desempenho ou segurança, ou porque para consultar tais dados esparsos deve-se acessar individualmente cada uma dessas fontes, o que é pouco eficiente;

c) a partir de um grande volume de dados, extrair informações relevantes, classificá-las e associá-las, tarefas imprescindíveis para o processo de tomada de decisão, tornam-se difíceis e trabalhosas de serem realizadas.(CABRAL, 2001)

Para suprir essas e outras carências dos sistemas de banco de dados no auxílio à tomada de decisões e para atender às necessidades dos analistas de negócios e dos 
profissionais com poder de decisão, em geral, as empresas passaram a construir os Datas Warehouses - depósitos unificados de dados.

O ambiente Data Warehouse é um repositório de dados derivados dos sistemas operacionais, armazenados sob um esquema único e organizados de forma a otimizar as consultas de apoio à tomada de decisão. Os dados desse ambiente devem ser pensados como uma visão materializada dos dados das fontes. Além disso, armazena informações históricas e não apenas dados correntes, uma característica importante para suportar processos decisórios. O Data Warehouse utiliza modelagem multidimensional, um tipo de modelagem mais simples para resolução de consultas analíticas do que para a abordagem relacional, sendo, portanto, mais adequada para suportar consultas de apoio à decisão (BOULLOSA, 2002).

A organização das informações, disponibilizadas clara e unificadamente, num só local e sem exigência de maiores conhecimentos tecnológicos para consultá-las, é o grande diferencial que a utilização de repositórios de Data Warehouse pode trazer na busca por economia de tempo e aumento dos lucros nas empresas.

No contexto web, uma utilização atual de Data Warehouse é a geração de fontes de dados de mapeamento de cliques - aplicação útil para tentar identificar padrões de utilização e extrair conhecimento de navegações pela internet. Portanto, a utilização de um ambiente Data Warehouse como ferramenta de apoio à tomada de decisões comerciais pode ser feita, por exemplo, identificando padrões no comportamento dos consumidores. Os dados de origem do clickstream, da internet, podem ser trazidos para serem analisados no ambiente Data Warehouse, em um data mart, subconjunto flexível, geralmente baseado em dados mais atômicos, exatamente do modo como qualquer outro dado é trazido para o ambiente. Obviamente, deve-se ter muito cuidado ao acoplar esse data mart às dimensões e aos fatos já utilizados no DW, para que o data mart se conecte ao barramento do Data Warehouse bus (KIMBALL, 2004). A importância do uso de internet é a atenção a um dos indicadores, conforme descrito no Anexo 1, exigido pela sustentabilidade: acesso à informação. 


\subsubsection{Business Warehouse - BW}

É um conjunto de ferramentas para gerenciamento da extração, transformação, armazenamento, consulta e análise de informações gerenciais. Este cria uma cópia de dados transacionais especialmente estruturados para consultas e análises, com a proposta de homogeneizar estruturas de informação Empresariais (operacionais e gerenciais), centralizando o aceso a informações e disponibilizando ferramental de fácil uso. O BW é o sistema de Data Warehouse da SAP, que trabalha em conjunto com o SAP R/3 (ERP) sumariando dados deste e de outros sistemas.

Os benefícios diretos observados após sua implementação são:

* Alta performance sem impacto aos Sistemas Transacionais;

* Aderência aos Objetivos Básicos de Data Warehouse;

* Favorecer Gestão Tática e Estratégica;

* Facilidade de Acesso;

* Implementação utilizando o Business Content (BCT);

* Ambiente de Alta Performance alimentado por fontes heterogêneas.

O sistema de Business Warehouse que é totalmente integrado ao R/3 está interligado (extração de dados) também aos sistemas legados e permite à Empresa analisar suas estratégias em real-time. O BW apresenta um conceito de inteligência de negócios, que visa à criação de uma nova ferramenta para geração de relatórios confiáveis para atender as exigências gerenciais assim como aos fiscais, auditores e acionistas. 
O sistema de Data Warehouse foi montado visando a extração de dados normalmente requisitados, com a intenção de flexibilizar os relatórios dados administrativos também podem ser apresentados, formando assim um sistema de drill down analysis (DDS) e executive information system (EIS). (ANAND, 1996) e (INMON, 2002).

Especificamente neste trabalho o sistema de Data Warehouse da SAP, o Business Warehouse, foi usado para extração de dados relevantes ao controle do fluxo de materiais. Estes dados ficam disponíveis na web para que as empresas que formam o ecossistema industrial possam trocar produtos fazendo com que o refugo gerado por uma empresa seja reaproveitado como matéria-prima em outra.

Como observado anteriormente, sistemas de ERP e Data Warehouse são mais utilizados por grandes empresas, devido ao seu alto custo e ao volume de dados que devem ser gerenciados, para empresas com menor circulação de dados a informatização também é observada, contudo com outros aplicativos, geralmente desenvolvidos sob encomenda. Portanto para estudos que tratem dados de empresas de médio e pequeno porte foram considerados sistemas desenvolvidos em uma linguagem de programação com licença livre e publicável na internet, para permitir a veiculação de dados, como o SQL.

\subsubsection{Interligação entre ERP e Ecologia Industrial}

Até o momento encontrou-se apenas um uso dos sistemas ERP para a implantação do conceito de Ecologia Industrial na construção do LCI (HENDRICKSON, 2001). Portanto, até o momento ACV é a metodologia privilegiada no uso dos sistemas ERP e algumas considerações serão feitas a seguir.

A Análise do ciclo de vida (ACV) tem se tornado uma ferramenta padrão para análise do impacto ambiental dos produtos e processos. Informações ambientais sobre os produtos comercializados vêm sendo requeridas pelos consumidores, mas a análise do ciclo de vida dos materiais é cara. Sistemas de ERP são normalmente usados para planejar, organizar, dirigir, medir e controlar a logística, finanças e recursos das organizações. Porém, como os sistemas de ERP contêm dados de produtos e processos 
estes também podem ser configurados para registrar informações relevantes para a análise do ciclo de vida e do impacto ambiental dos produtos, já que podem informar o peso das matérias primas e suprimentos, uso de água e energia, como lista de componentes e ordens de produção, etc.

A necessidade de informações sobre o ciclo de vida dos materiais vem crescendo na última década também devido a exigências legais, como as legislações ambientais na Europa que obrigam as empresas a apresentar dados do impacto ambiental de seus produtos. Para o setor eletroeletrônico as diretrizes da União Européia - Waste Electrical and electronic Equipament (WEEE), Restriction of the Use of Certain Hazardous Substances in Electrical and Electronic Equipament (SÉRGIO, 2005) - são bastante restritivas. Estas diretrizes requerem relatórios sobre os compostos dos produtos eletrônicos, restringindo o uso de certas substâncias e estimulando a reciclagem dos resíduos de maneira ambientalmente correta. Outra pressão pode vir de acordos internacionais porque, apesar do item 12 da Carta do Rio considerar a legislação ambiental problema interno de cada país, os acordos internacionais de comércio permitem que um importador faça as mesmas exigências que são feitas internamente aos seus fabricantes.

Um modo de contornar o problema é o ACV simplificado e/ou a rotulagem ambiental. Contudo, nos dois casos é comum seguir fluxo de materiais na produção de um bem ou pelo menos em algumas etapas. Por outro lado, o controle do fluxo de materiais é premissa do metabolismo ambiental, considerado necessário para implantação do conceito de Ecologia Industrial e formação de ecossistemas industriais. Portanto, as matrizes propostas para o ACV simplificado também podem ser usadas para reconhecimento do fluxo de materiais, ou seja, determinação de como ocorre o metabolismo industrial, ou mesmo propô-lo dentro de um ecossistema existente ou a ser implantado.

\subsection{O Setor Eletroeletrônico}

É consenso entre muitos autores que o advento dos dispositivos semicondutores melhorou as condições ambientais por inúmeras razões (ZUFFO, 2003) e que impactam 
toda a cadeia produtiva (MCDONNELL, 1999). Portanto, qualquer provável melhoria nessa cadeia deve se propagar positivamente, num circulo virtuoso como propõe Zuffo, por toda a sociedade.

Silva (2004) descreveu brevemente o setor eletroeletrônico, utilizando um gráfico de Ishikawa, como o apresentado na Figura 1.4 suas principais conclusões são como segue:

"A indústria de base do setor (a microeletrônica) trabalha com grandes volumes de produção e consome grandes volumes de água e reagentes químicos. Devido às exigências de baixa contaminação, os dois insumos (água e reagentes químicos) podem ser facilmente reaproveitados em outras empresas, especialmente as galvânicas e as de circuitos impressos, que demandam menor pureza...Outra vantagem dessas empresas é o pequeno número, o que facilita montar parcerias para consumo de seus resíduos".

“Após a fabricação dos CI's estes serão acoplados a placas, de circuito impresso ou em superfície (SMT, surface mounting technology). As empresas que fazem a montagem eletrônica já estão mais disseminadas e o consumo de seus resíduos fica muito dependente de parcerias, principalmente com os fornecedores..." 


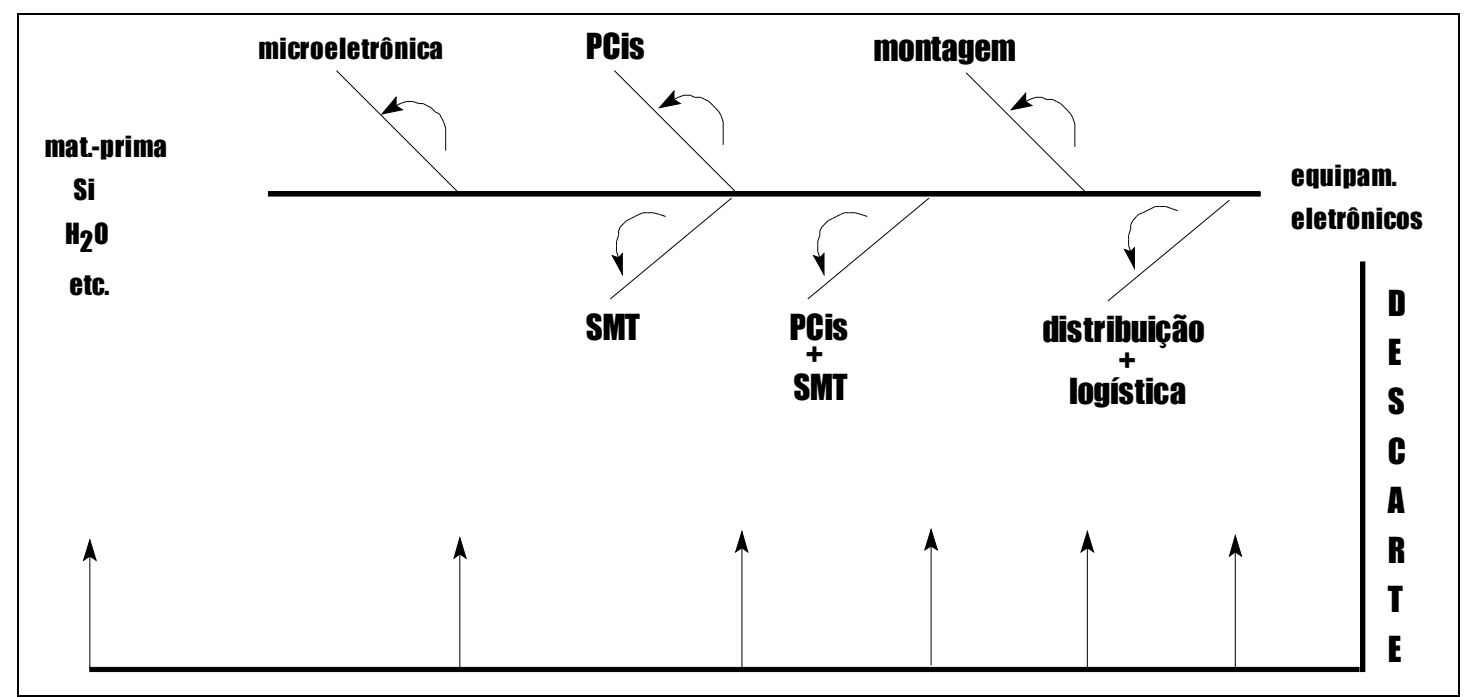

Figura. 1.4 Gráfico de Ishikawa da produção no setor eletroeletrônico. As flechas indicam possibilidades de montagem de ecossistemas industriais internos ou externos

(PCI - placa de circuito impresso, SMT - surface mounting technology)

"Atualmente os equipamentos eletrônicos tendem a ser modulares, favorecendo a desmontagem e o "up grade", o que vai ao encontro com o desejado pela Ecologia Industrial... Nota-se um crescente interesse na desmontagem das placas sucateadas ou dos equipamentos em todo o mundo ... para grandes volumes, a reutilização é muito simples e, novamente, pode ser feita no processo de parceria. Cartucho de impressão é outro estudo de caso bem conhecido, onde o reciclador não precisa ser o produtor."

Por fim, Gameiro (2002b) demonstrou que as empresas de base de microeletrônica do país possuem galvânicas acopladas e que estas são ecossistemas "naturais" para água.

\subsection{Considerações Finais}

Os aspectos teóricos elencados neste capítulo permitem observar uma série de características similares, mas eventualmente díspares, entre indicadores, ferramentas e definições de sutentabilidade.

A maioria dos indicadores listados pelos diversos atores interessados na questão da sustentabilidade, de modo geral, são semelhantes, contudo, apenas a Ecologia Industrial considera a importância de definir trocas entre vários sistemas de produção e, mais 
especificamente, de propor a formação de ecossistemas industriais. Do mesmo modo, as trocas são melhor descritas dentro do contexto de metabolismo industrial, que pressupõe a definição de produtores primários como qualquer produtor que possua material em quantidade suficiente para estabelecer trocas significativas com outros da cadeia de transformação o que reassegura a importância dos recicladores dentro da formação do sistema.

É importante salientar que os indicadores via de regra são apresentados na forma de uma planilha, não parecendo ocorrer nenhuma prevalência de uso de software, como os software de controle de processo, que poderiam levar à obtenção rápida de dados e facilitar a comunicação entre produtores distintos, o que é uma das grandes exigências da Ecologia Industrial e uma das grandes vantagens do uso de software: rapidez de comunicação.

A busca de propostas que conciliem as atividades produtivas com a capacidade de suporte do planeta tem levado à elaboração de alternativas que convergem e divergem em vários aspectos. Neste texto apresentaram-se argumentos dos defensores da Prevenção da Poluição e Produção Mais Limpa, por um lado, e da Ecologia Industrial, por outro. 


\section{METODOLOGIA}

Esse trabalho levantou, de modo qualitativo e exploratório, as principais informações para a aplicação do conceito de Ecologia Industrial usando como ferramenta o controle do processo por software. Portanto, para avaliar quais são os parâmetros relevantes para constar desse controle dois modos distintos são efetuados: pesquisa bibliográfica e análise de campo. A pesquisa bibliográfica compõe-se de dois tópicos distintos: a) indicadores ambientais e ferramentas da Ecologia Industrial e b) softwares de controle de processo, para permitir uso eficiente na implantação do conceito de Ecologia Industrial. A análise de campo pressupõe simulação e uso de dados reais no software. Após essas etapas cria-se um corpo de sugestões (metodologia) para implantação por comparação entre as empresas avaliadas e a situação encontrada atualmente.

O fluxograma de decisão da Figura 2.1 descreve sucintamente as etapas adotadas para a elaboração deste trabalho. Procede-se, como descrito nos aspectos teóricos, a um levantamento bibliográfico das ferramentas usadas para implantação da Ecologia Industrial e da Produção Mais Limpa principalmente e, também, de indicadores e índices de sustentabilidade de acordo com os vários atores (stakeholders) envolvidos na questão ambiental. A partir da comparação das ferramentas propostas e os indicadores levantados, cria-se uma matriz, que corresponde ao mínimo necessário para implantar-se o conceito e garantir que esta implantação está de acordo com as propostas de sustentabilidade. A partir dessa matriz define-se com utilizar o software já existente, ou propõe-se uma alternativa. Os estudos de caso validam a matriz e ao mesmo tempo permite verificar possíveis melhorias de processo. Portanto, a metodologia assemelha-se à proposta de melhoria contínua (plan-do-check-act) da norma ISO 14001.

De acordo com Silva (2001) dentre os possíveis métodos de pesquisa científica o método fenomenológico, que não é dedutivo nem indutivo, preocupa-se com a descrição direta da experiência tal como ela é e pode ter como ferramenta o estudo de caso. O estudo de caso aliado a uma abordagem exploratória do problema foi escolhido como ferramenta metodológica para esse trabalho pelos motivos expostos a seguir. $\mathrm{O}$ estudo de caso é muito utilizado na área da Engenharia de Produção e, segundo Silva, "Engenharia de Produção caracteriza-se como uma engenharia de métodos e de procedimentos. Seus 
objetivos são o estudo, o projeto e a gerência de sistemas integrados de pessoas, materiais, equipamentos e ambientes. Procura melhorar a produtividade do trabalho, a qualidade do produto e a saúde das pessoas (no que se refere às atividades de trabalho)... A área de Engenharia de Produção tem uma abordagem interdisciplinar como suporte da sua construção cognitiva. Nesse sentido está envolvida com diversas Ciências Humanas, em particular com a Economia e as ciências da organização (que envolvem temas ligados à Administração, à Sociologia, às Ciências Ambientais, à Psicologia e à Matemática Aplicada)". Assim, nota-se que a definição de metodologia semelhante à área de Engenharia de Produção é bastante adequada para essa proposta de trabalho, daí o uso do estudo de caso.

Segundo Danton (2002), o estudo de caso apresenta algumas premissas a serem preenchidas, pois "o caso é tomado como unidade significativa do todo e apresenta três fases: 1 - Seleção e delimitação do caso; 2 - Trabalho de campo; 3 - Organização e redação do relatório. O estudo de caso pode incluir várias outras técnicas: entrevista (diretiva e não diretiva), análise de conteúdo, observação (sistemática ou participante), questionário...". Resumidamente pode-se dizer que nos estudos de caso será utilizada abordagem semelhante à usada em auditorias da série ISO, uma vez que há interesse em levantamento de indicadores.

\subsection{Especificação das Condições de Contorno}

A seleção do setor industrial a ser estudado considerou algumas premissas da Ecologia Industrial. Presume-se que para existir metabolismo industrial significativo há a necessidade de produção em larga escala e alto valor agregado do produto e prováveis coprodutos. Para estes dois aspectos toda a cadeia do setor eletroeletrônico apresenta condições altamente favoráveis (ZUFFO, 2003). Outro fator relevante é a possibilidade de formação de ecossistemas industriais, internos ou externos à empresa. Estudo anterior (GAMEIRO, 2002) já provou que ecossistemas industriais podem ocorrer na área de Microeletrônica. Contudo, deve-se observar que os ecossistemas externos podem ser formados considerando a cadeia de produção ou parceiros distintos. Os estudos de Zuffo (2003) indicam que provavelmente o setor possui intenso metabolismo industrial e é 
também bastante favorável para estabelecimento de ecossistemas industriais, principalmente aliando-se a cadeia de produção. Por fim, deve-se observar que o uso de tecnologias ambientalmente corretas (GAMEIRO, 2002) está disseminado pelo menos no início da cadeia, o que também pode ser útil na formação de ecossistemas industriais.

O sistema utilizado neste trabalho foi na maioria das vezes o Enterprise Resource Planning SAP R/3 e o critério para sua escolha é a ampla utilização, como será explicado no capítulo 3. Resumidamente, pode-se dizer que este sistema é utilizado por cerca de $70 \%$ das grandes empresas de tecnologia eletrônica, possui recursos de geração de relatórios para suporte a decisão, listas de componentes de cada produto, controle de estoque, acompanhamento do processo fabricação e das etapas de compra e venda, além de um sistema de informação logística que pode ser usado para administração de transportes, reduzindo a emissão de gás carbônico em viagens desnecessárias. É importante salientar que, como este software não é comum em pequenas e médias empresas, para estas, sempre que possível, optou-se pelo uso de planilhas. 


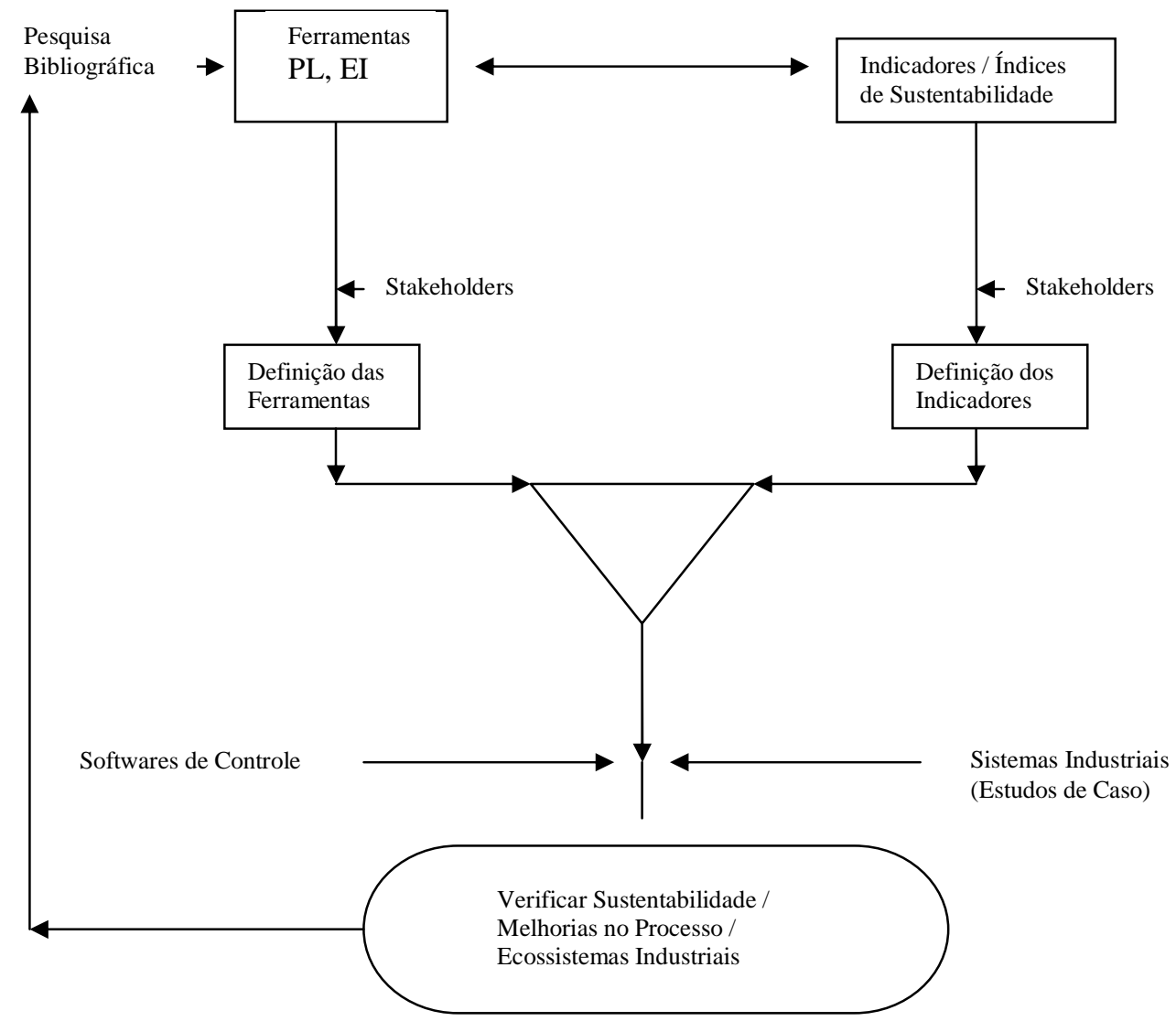

Figura 2.1 - Fluxograma de decisão para definição de metodologia para aplicação

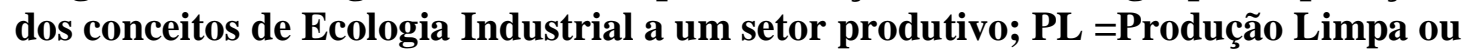
Mais Limpa e EI=Ecologia Industrial 


\section{RESULTADOS DE DISCUSSÃO}

Este capítulo mostra os resultados obtidos para a aplicação do conceito de Ecologia Industrial ao Setor de Eletroeletrônicos usando software de controle de processo. O capítulo encontra-se dividido principalmente em considerações sobre o setor, indicadores relevantes para a Ecologia Industrial, proposta de metodologia para o uso de software e respectivos estudos de caso.

\subsection{Composição do setor eletroeletrônico no país}

Para a aplicação do conceito de Ecologia Industrial no setor de eletroeletrônico, inicialmente fez-se uma avaliação deste quanto aos seguintes parâmetros:

- Perfil das empresas: pequenas, médias e grandes;

- Utilização de software, e especificamente SAP, para controle de processos;

- Distribuição das empresas pelas grandes áreas que compõem o setor.

Para avaliar a composição do setor utilizou-se as informações constantes nas associações de classe, principalmente FIESP (Federação das Indústrias do Estado de São Paulo), ABINEE (Associação Brasileira da Indústria Elétrica e Eletrônica) e ABRACI (Associação Brasileira de Circuitos Impressos). As informações foram obtidas não só pela consulta dos sites mas também por contato direto com representantes. Há vários parâmetros que podem ser usados para a definição de pequenas e médias empresas, como pode ser visto no Anexo 3. Este trabalho utilizou o conceito do número de funcionários, por ser o mais comumente utilizado nas publicações especializadas e também o aceito pelo SEBRAE (Serviço Brasileiro de Apoio às Micro e Pequenas Empresas).

A composição encontrada foi de $29 \%$ para Microempresas, 34\% de Pequenas e $16 \%$ de Média empresas, com apenas $21 \%$ de Grandes empresas. Quanto à distribuição destas por ramo de negócios a ABINEE informa uma composição como a encontrada na Tabela 3.1. 


\section{Tabela 3.1 Distribuição do ramo de negócio da indústria de eletrônicos no Brasil, segundo ABINEE}

\begin{tabular}{|l|l|}
\hline Ramo de Negócio & Percentual \\
\hline Automação Industrial & 13 \\
\hline Componentes Eletroeletrônicos & 12 \\
\hline Equipamentos Industriais & 13 \\
\hline Geração e Distribuição de Energia & 7 \\
\hline Informática & 14 \\
\hline Material Elétrico de Instalação & 14 \\
\hline Telecomunicações & 17 \\
\hline Utilidades Domésticas & 10 \\
\hline
\end{tabular}

Quanto à distribuição das empresas pelas grandes área, de acordo com o gráfico de Ishikawa apresentado no primeiro capítulo deste trabalho, utilizando a informação das associações, é como segue:

- Na área de base (Microeletrônica) encontram-se apenas três empresas, localizadas em São Paulo, sendo que uma deve estar completamente fora do mercado em breve. Os insumos destas empresas foram levantados por Gameiro (2002), como será visto posteriormente. Um pólo de Microeletrônica deverá ser ativado em Porto Alegre em breve, de acordo com informações da SBmicro (Sociedade Brasileira de Microeletrônica). Todas estas correspondem a pequenas empresas.

- Na área de PCI's e SMT pelo menos 40 empresas atuam, e estas têm contato direto (fornecedores) com pelo menos outras 40, como pode ser visto pela análise do site da ABRACI. Estas empresas encontram-se disseminadas no país, mas com prevalência de sítios em S. Paulo e Manaus, principalmente. Todas estas correspondem a pequenas empresas.

- Montagem de equipamentos corresponde a um vasto campo de atuação, e não foi possível estimar todas as empresas existentes. Associadas à ABINEE existem cerca de 100 empresas, com a distribuição no ramo de negócios como descrita na Tabela 3.1, mas o uso/montagem de componentes eletrônicos é vastamente disseminado, não 
permitindo uma avaliação mesmo que semi-quantitativa da composição por estado, no que concerne ao número de empresas. O mesmo ocorre com a distribuição de tais equipamentos. Neste segmento encontram-se empresas de todos os portes: pequena, média e grande.

Quanto ao uso de software para controle de processo, considerou-se as empresas mais diretamente ligadas ao setor, e portanto constantes da base de dados de associações como ABINEE e ABRACI, e verificou-se - por contato direto com a empresa ou com fornecedores de software - se ocorria o uso de um sistema ERP na empresa. A distribuição do uso de sistemas ERP em função do tamanho das empresas é mostrada na Figura 3.1. Assim, pode-se observar que aproximadamente metade das empresas usam algum tipo de software de controle. Porém, a distribuição desse uso em função do tamanho assemelha-se ao que é encontrado na bibliografia, como descrito no capítulo 1 , com as grandes empresas usando maciçamente tais softwares, mas não as médias e ainda em menor extensão as pequenas.

Também foi verificado quanto destes sistemas ERP's correspondem ao SAP R/3. Essa verificação ocorreu por dois modos distintos: avaliação da bibliografia disponível e pesquisa com fornecedores do software. A SAP confirmou estar presente em $70 \%$ das grandes empresas e a pesquisa de Roselino (2000), que objetivava avaliar o uso de software no país, também confirma tal resultado. O Anexo 4 apresenta os resultados tabelados por Roselino (2000) no que concerne a valor de faturamento em função do software utilizado pela empresa. É possível observar que empresas grandes usam software SAP, mas especialmente as pequenas valem-se de software próprio, para diminuir custo. Por fim, deve-se salientar que no referido trabalho o tamanho da empresa foi definido a partir de seu faturamento. 


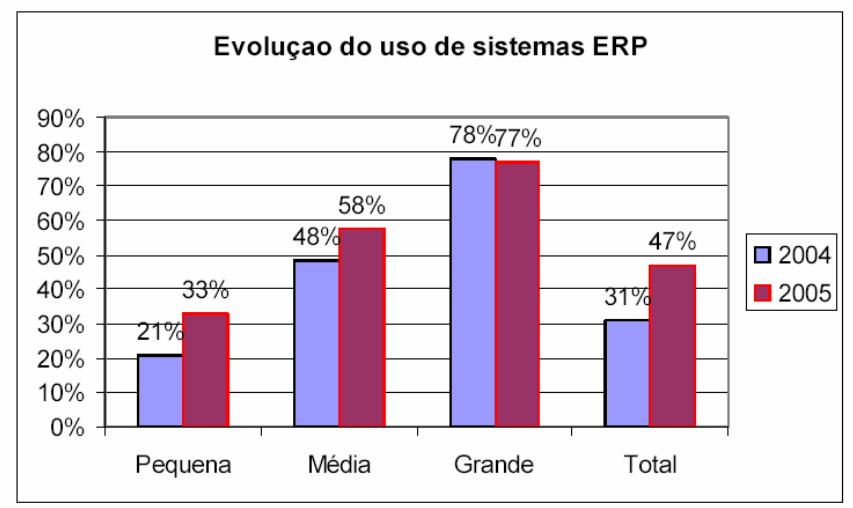

\section{Figura 3.1. Porcentagem de uso no setor eletroeletrônico brasileiro de sistemas ERP's em função do tamanho da empresa. As informações correspondem aos anos de 2004 e 2005.}

Utilizando os valores obtidos anteriormente, nota-se que o uso do software da SAP beneficia diretamente, no mínimo, $20 \%$ da população do setor eletroeletrônico, o que justifica seu uso para os estudos de caso, uma vez que outro software atingiria uma população menor. Por outro lado, a proposta de solução de controle e/ou melhoria de processo que não dependa do uso de um software dedicado é atrativa para as pequenas empresas, que correspondem a grande número na cadeia em questão.

\subsection{Premissas de Ecologia Industrial, Ferramentas e Indicadores Ambientais}

Como abordado no capítulo 1 deste trabalho, duas premissas da Ecologia Industrial devem ser consideradas para a implantação do conceito em qualquer empreendimento: metabolismo industrial e ecossistemas industriais.

Muito embora não se tenha encontrado proposta para avaliação do metabolismo industrial de um empreendimento ou setor, como anteriormente mencionado, uma matriz como a utilizada em ACV simplificado pode ser uma ferramenta útil para avaliar tais fluxos. Além disso ACV simplificado pode ser útil para obtenção de várias outras informações, pois a Ecologia Industrial exige, como descrito pela UNEP, balanceamento de entradas e saídas, desmaterialização com melhoria de eficiência dos processos industriais e uso eficiente de energia, o que também pode ser verificado pela metodologia de ACV. Observe-se que a desmaterialização, para atender a idéia do metabolismo industrial e também tornar os sistemas de produção mais próximos dos sistemas naturais, também atende aos requisitos de ecoeficiência, como definido pelo WBCSD. Por outro 
lado, o projeto para o ambiente está apenas indiretamente associado à ACV. Contudo, pode-se verificar, mesmo que indiretamente, sua aplicação, pela existência de normas ou recomendações adotadas no empreendimento.

Quanto aos ecossistemas industriais, além de cumprir os requisitos da Produção Mais Limpa, que exigem o uso de tecnologias mais limpas e a comunicação ambiental, pelo direito de saber, recomenda-se a existência de meios eficientes de comunicação entre os vários parceiros do ecossistema. A comunicação ambiental, e a rotulagem ambiental, também são requisitos das normas ISO. Por fim, a responsabilidade social é considerada como fundamental para a obtenção da sustentabilidade embora não possa ser imediatamente associada ao conceito de Ecologia Industrial. Contudo, deve-se salientar que a UNEP sugere como elemento da Ecologia Industrial políticas de longo prazo.

A Tabela 3.2 resume as considerações feitas anteriormente e as associa com os indicadores de sustentabilidade descritos no Anexo 1. É possível observar $69 \%$ dos indicadores listados no Anexo 1 podem ser atendidos pela aplicação do conceito de Ecologia Industrial utilizando as ferramentas propostas por diversos autores. Deste modo, considerando-se, também, a definição de tripé de sustentabilidade pode-se atender $100 \%$ dos indicadores. Observe-se, novamente, que o atendimento às normas que descrevem internacionalmente tal tripé está pelo menos parcialmente contemplada no conceito de Ecologia Industrial. Quanto aos atores ambientais (stakeholders) como definido no capítulo 1, percebe-se que a maioria - se não a totalidade - será contemplada pelo uso do conceito de Ecologia Industrial, uma vez que a informação deve estar disponível de várias formas, para permitir a formação dos ecossistemas industriais.

Tabela 3.2 Relação entre Ecologia Industrial os indicadores de sustentabilidade descritos no Anexo 1.

\begin{tabular}{|l|c|}
\hline Ecologia Industrial & $\begin{array}{c}\text { Indicadores de sustentabilidade } \\
\text { (dimensão de acordo com Anexo 1) }\end{array}$ \\
\hline \multicolumn{2}{|c|}{ Metabolismo industrial } \\
\hline ACV simplificado: Matriz & Natureza do produto \\
\hline Desmaterialização & Natureza do produto \\
\hline Reciclagem & Política ambiental \\
\hline \multicolumn{2}{|c|}{ Ecossistema Industrial } \\
\hline Produção Mais Limpa & Política ambiental \\
\hline Comunicação ambiental & Governança \\
\hline \multicolumn{2}{|c|}{ Tripé de sustentabilidade } \\
\hline
\end{tabular}




\begin{tabular}{|l|c|}
\hline Normas de qualidade & Compromisso \\
\hline Normas ambientais & Política ambiental e compromisso \\
\hline Normas de responsabilidade social & Compromisso \\
\hline
\end{tabular}

Após a definição das principais necessidades para implantação do conceito (Tabela 3.2), avaliou-se quais funcionalidades do software SAP R/3 atendiam estas demandas e a Tabela 3.3 resume as possíveis conexões. A análise de funcionalidades considerou o menor caminho possível porque há muitos caminhos da informação pelos blocos do programa, como o resumo apresentado no capítulo 1 permite averiguar.

Tabela 3.3 Principais demandas para implantação da Ecologia Industrial e possíveis conexões com o SAP R/3

\begin{tabular}{|l|l|}
\hline Demandas & $\begin{array}{l}\text { Funcionalidades do Sistema SAP } \\
\mathbf{R} / \mathbf{3}\end{array}$ \\
\hline Desmaterialização & Pedidos de Compra \\
\hline Reciclagem & $\begin{array}{l}\text { Dados Mestres de Materiais e Lista } \\
\text { Técnica de Componentes }\end{array}$ \\
\hline $\begin{array}{l}\text { Responsabilidade Social } \\
\text { (SA8000) }\end{array}$ & HR, FI \\
\hline Ecossistemas Industriais & MRP e BW \\
\hline Contabilidade Ambiental & MM e PP \\
\hline AVC & Fluxo de materiais e RFID (LCI) \\
\hline ISO 9000 e semelhantes & QM \\
\hline Produção Limpa & Processo de Produção e ACV \\
\hline
\end{tabular}

Sendo HR ( Human Resources), FI (Financial Accounting), MRP (Material Resource Planning), BW (Business Warehouse), MM (Material Management), PP (Production Planning), RFID (Radio Frequency Identification), LCI (Life Cycle Analyses), QM (Quality Management), ACV (Análise do Ciclo de Vida).

Para verificar-se a desmaterialização, o controle do fluxo de materiais é fundamental, assim como a análise histórica deste fluxo. Portanto, para atender esta demanda, os pedidos de compra mostraram-se adequados, pois estes são cadastrados e arquivados com dados de localização e quantidade do material consumido.

A demanda de dados exigida para o estímulo da reciclagem foi atendida pelos dados mestres de materiais e pela lista técnica de componentes, considerando que com estas funcionalidades pode-se rastrear toda a composição de um produto em massa, propriedades físico-químicas como toxidade além da condição de uso. Esta funcionalidade foi testada com relação a anterior (pedido de compra) e mostrou-se mais adequada para a reciclagem porque possui mais dados, como toxidade, enquanto o pedido de compra mostrou-se mais adequado para a demanda anterior (desmaterialização) por 
manter um histórico, enquanto os dados mestres refletem apenas os produtos em estoque atualmente.

A responsabilidade social é atendida pelos módulos de HR (Human Resources) e pelo de FI (Financial Accounting) com os indicadores da SA 8000 extraídos dos relatórios destes módulos.

Os ecossistemas industriais são estimulados pelo MRP (Material Resource Planning) e pelo BW (Busines Warehouse), o MRP controla a necessidade de materiais e, com esta informação divulgada na web pelo $\mathrm{BW}$, as empresas sabem quais co-produtos são necessários em outras empresas.

A contabilidade ambiental é assistida pelos módulos de MM (Material Management) e PP (Production Planning), juntos estes módulos controlam cada etapa do processo de produção fornecendo informações relevantes para uma contabilidade ambiental, como quantidade de insumos e produtividade.

Já na Analise do Ciclo de Vida (ACV) o sistema SAP R/3 mostrou-se capaz de fornecer dados importantes do fluxo de produtos e insumos, como citado em Hendrickson (2001). Em empresas que utilizam o RFID (Radio Frequency Identification) o ACV é facilitado pela automação na aquisição de dados, como, por exemplo, a origem, destino e composição do produto.

A aplicação de normas como a ISO 9000 é facilitada pelo módulo de QM (Quality Management), este impõe restrições ao recebimento de materiais de acordo com regras pré-estipuladas. No caso da Produção Mais Limpa o sistema mostrou-se eficaz para atender seus preceitos com o controle e fornecimento de indicadores dos processos de produção e com o AVC, como descrito anteriormente.

\subsection{Metodologia para uso do software SAP R/3}

Os caminhos utilizados no software SAP R/3, como explicado no item anterior, apresentam algumas características, principalmente vantagens e/ou limitações, que serão melhor descritas nesse item. Apenas para melhorar a visualização das respostas obtidas várias telas são apresentadas neste item, contudo, esta não é a única configuração possível e não necessariamente corresponde a uma solução definida como otimizada. 
A descrição dos caminhos utilizados no software tem como objetivo explicitar como cada item foi definido e rastreado dentro deste. É importante salientar, contudo, que estas soluções não são únicas e que podem ser implantadas utilizando-se outros softwares e, portanto, correspondem apenas a sugestões de procedimento. Do mesmo modo, a ordem de apresentação destas funcionalidades não foi alfabética, mas de modo a favorecer a compreensão das diversas funcionalidades.

\subsubsection{Desmaterialização}

A desmaterialização é aqui definida como a redução do uso de insumos e/ou a substituição deste insumo por outro cuja fabricação demande menos recursos. Dentro desta definição a dematerizalização pode ser quantitativamente controlada pelo uso do software. Um possível caminho, tanto para produtos como para processos, é o levantamento das entradas que certo insumo teve no empreendimento, e uma comparação histórica com dados internos e externos.

As entradas de materiais, em um empreendimento que utiliza o sistema de ERP em questão, podem ser iniciadas de diferentes maneiras: contratos, requisições de compras, programa de remessas ou automaticamente pelo MRP (Material Resource Planning), este último inicia o processo de compra de acordo com a configuração imposta. Na maioria dos casos fazendo uma varredura no estoque e considerando o histórico das necessidades.

No entanto, apesar do processo de aquisição de materiais ser iniciado de diferentes maneiras e por diversas necessidades, qualquer entrada física na fábrica é feita por intermédio de um pedido de compras. Isto ocorre para que o sistema possa controlar de forma clara o pagamento de fornecedores, a emissão de notas fiscais e os livros de balanço.

Portanto, fica evidente que o levantamento dos pedidos de compra para cada material, levando em conta que cada material comprado tem um código específico e que os pedidos de compras podem ser rastreados por este código, é de suma importância para que a desmaterialização possa ser comprovada. Assim, um levantamento histórico da entrada de materiais ou a comparação com outras indústrias semelhantes, 
proporcionalmente ao volume de produção, pode estimular e/ou comprovar a desmaterialização.

A Figura 3.2 mostra um exemplo de um pedido de compra, nota-se que diversos dados, tais como quantidade, valor, fornecedor, forma de entrega e de pagamento, podem ser usados para definir os índices relativos à desmaterialização. É importante observar que estes dados podem ser utilizados para comprovar a desmaterialização não só internamente ao empreendimento como também na etapa anterior e posterior da cadeia. Como exemplo tem-se o controle da emissão de gás carbônico durante o transporte. Como os dados mestres de fornecedores/clientes indicam sua localidade e valores médios de emissão existem para todos os tipos de transporte, é possível controlar para diminuir tal impacto.

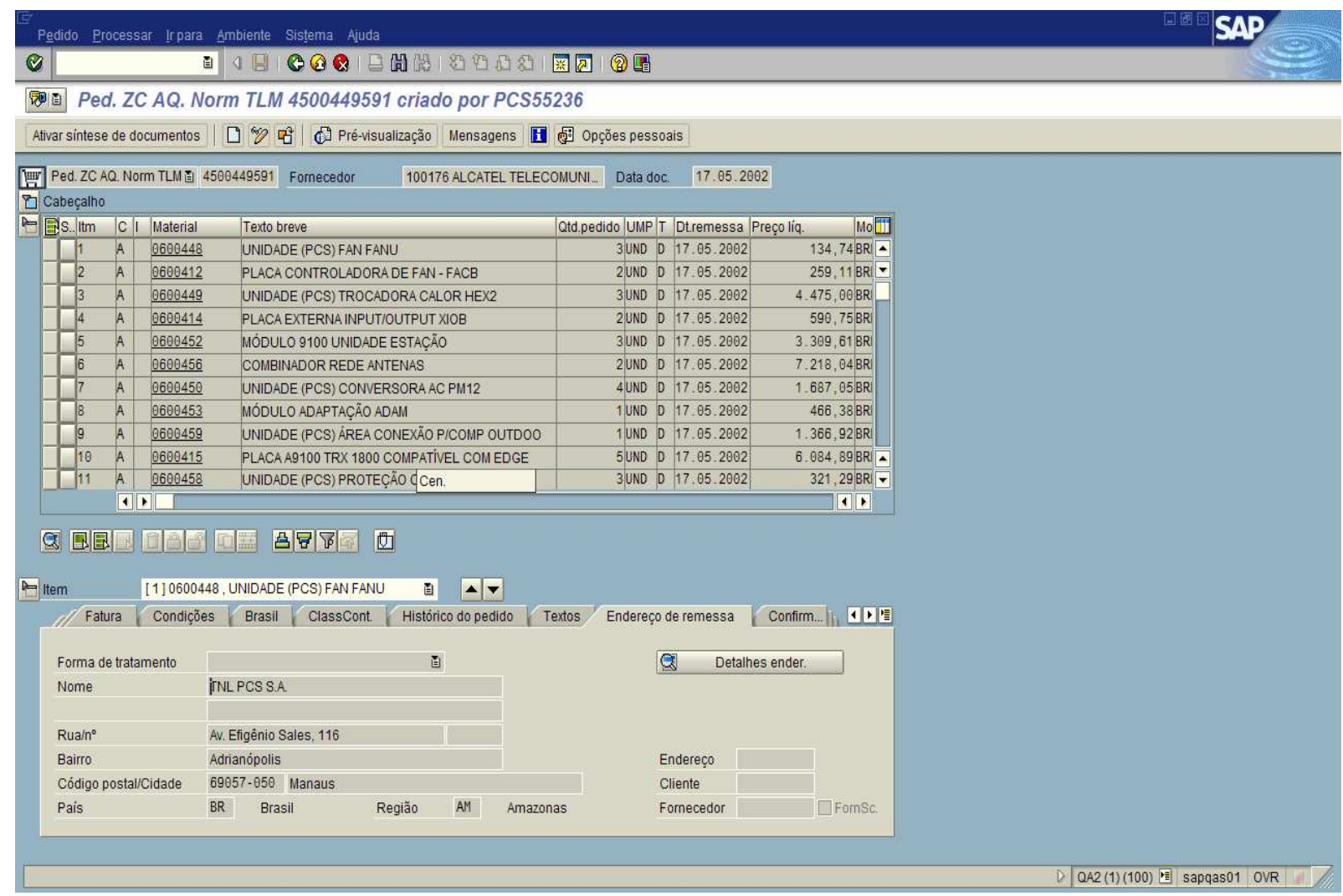

Figura 3.2 Exemplo de pedido de compra, tela contida na transação ME23N do SAP R/3.

A Figura 3.3 sumaria, por diagrama de blocos, como os dados referentes à desmaterialização são extraídos do sistema neste trabalho. Resumidamente, como todas 
em entradas de materiais são feitas através de pedidos de compras, dados de consumo de cada insumo são levantados levando em conta cada componente em um balanço de massas, conforme indica o LCI (life cicle inventories), estas informações alimentam o relatório do Business Warehouse que são visualizados pelos indicadores. Estes indicadores podem ser colocados em uma planilha, criando assim um balance scorecard (BSC). Assim, uma análise histórica do consumo (AHC) e a análise comparativa de consumo (ACC) com outras empresas pode ser feita, proporcionalmente ao volume da produção, comprovando-se deste modo a desmaterialização. A escolha da produção de um BSC com os dados de saída deve-se às vantagens que este apresenta para a tomada de decisão e definição de estratégias empresariais. O Anexo 5 define o BSC e explica suas principais propriedades.

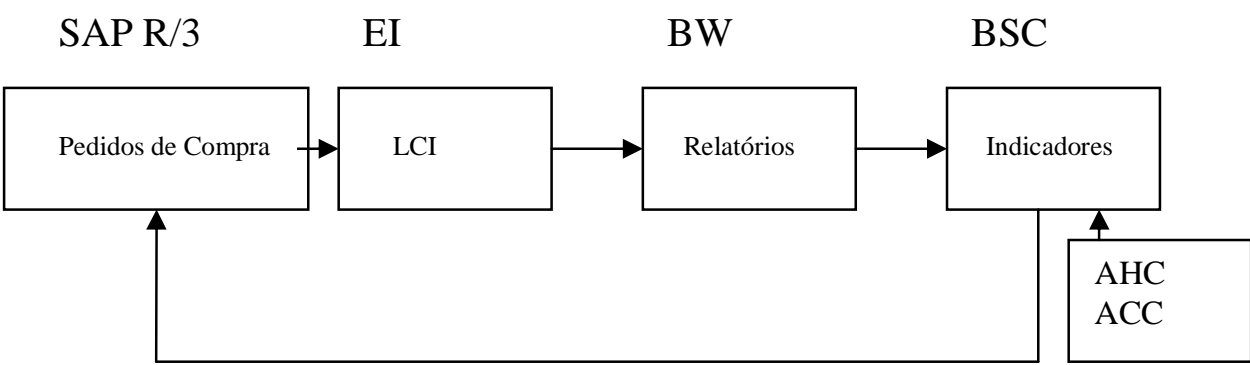

Figura 3.3 Extração de Indicadores referentes à desmaterialização. Sendo LCI (Life Cycle Inventories), EI (Ecologia Industrial), BW (BusinessWarehouse), BSC (Balance Scorecards), AHC (Análise Histórica de Consumo), ACC (Análise Comparativa de Consumo).

Via BSC também é possível a comparação de dados entre empresas. Tal informação não fica evidenciada diretamente no sistema das empresas, mesmo que estas possuam o mesmo software. Assim, observa-se a importância de definição de sistemas de comunicação entre empreendimentos, para que ocorra a troca de informações e dados, além da troca de insumos, para a aplicação do conceito de Ecologia Industrial.

\subsubsection{Reciclagem}

A reciclagem aqui é compreendida de dois modos distintos: por formação de ciclos internos e ciclos externos. No primeiro caso um insumo é reutilizado dentro do 
empreendimento e no outro em outro local. Esta definição de reciclagem também comporta a definição de co-produto, como discutida no capítulo 1.

A reciclagem pode ser controlada por dados existentes no SAP R/3 porque informações relevantes para esta, como a origem, destino e composição, além da classificação dos produtos e insumos estão cadastrados nos dados mestres dos materiais. A idéia de co-produto também pode ser inserida desde que o sistema seja customizado. Para isso é necessário criar uma classe especial de produto dentro do sistema.

Verificou-se entre as empresas que usam o sistema, através de contato com consultoria especializada, se a definição de co-produto já havia sido inserida em algum empreendimento. Foi encontrado um caso, na área metalúrgica ${ }^{2}$. A classe especial criada para co-produtos foi genericamente denominada sucata. Quando o sistema passou a informar também materiais aparentemente sem utilidade, o MRP, juntamente com os dados mestres de materiais, tornou possível uma análise e a conseqüente tomada de ações por toda a instituição e culminou no aumento da destinação dos co-produtos em $67 \%$. Os dados mestres mostraram que as fábricas das filiais consumiam um componente que era descartado pela matriz, assim o MRP calculou a necessidade das filiais e a quantidade de co-produto produzido pela matriz, fechando o ciclo.

Cada equipamento produzido, comprado ou vendido por uma empresa que utiliza um sistema de ERP, deve estar cadastrado com seus dados mestres devidamente preenchidos. Os dados mestres de um material possuem todas as informações de um produto, como por exemplo peso, dimensões, preço médio, classe de material, validade, localização, controle de qualidade e etc. Estes dados podem facilitar a reciclagem e/ou estimulá-la, por exemplo pela demonstração do ganho econômico que a empresa teria com o uso de materiais reciclados ou pela venda de co-produtos.

O SAP R/3 tem em seus dados mestres de materiais uma funcionalidade que pode ser muito bem aproveitada para a reciclagem, e conseqüentemente para a Ecologia Industrial, que é a lista técnica de materiais. Esta funcionalidade descreve cada componente usado na produção de um equipamento ou obra, incluindo insumos como água e energia. Isto garante um acesso ágil aos dados mestres de qualquer outro material

\footnotetext{
${ }^{2}$ Descrição conseguida por entrevista
} 
envolvido no processo produtivo e deixa explícita a quantidade de insumos usados durante o processo produtivo.

Analisando a lista técnica de um produto e rastreando-se as listas técnicas de cada insumo deste pode-se chegar até a matéria prima básica e demonstrar o volume necessário desta, o que corresponde aproximadamente a um ACV simplificado. Assim o ganho econômico do uso de matérias primas recicladas e venda de co-produtos podem ser estimados com grande precisão.

A Figura 3.4 traz parte dos dados mestres de um equipamento fictício, um rádio $\mathrm{AM} / \mathrm{FM}$, e sua lista técnica. Esta simulação será melhor explicada posteriormente e tem como objetivo a validação da customização proposta neste trabalho. Pelo sistema podemse rastrear os dados mestres de cada material que consta na lista técnica em uma única etapa, por um processo denominado drill down, o que facilita a busca até as matériasprimas básicas.

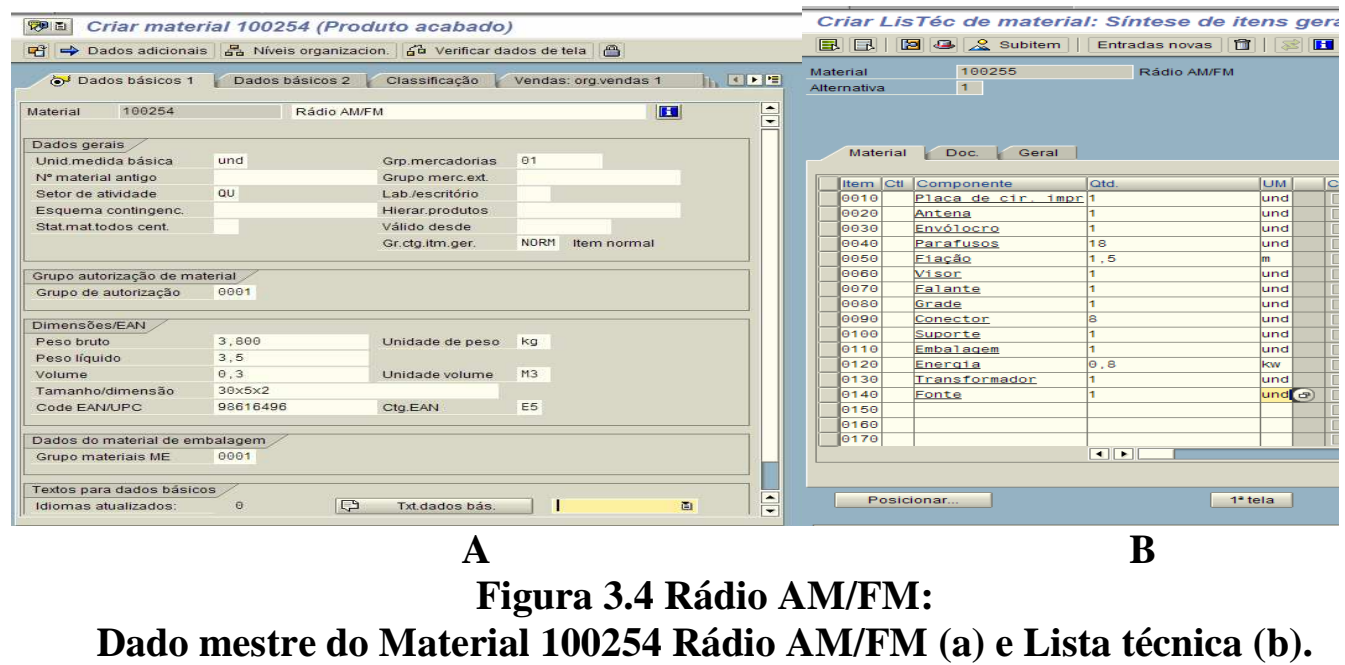

Contudo na maioria dos casos a lista técnica de componentes traz materiais que são fabricados em outras indústrias e somente estas possuem seus respectivos dados mestres de materiais de forma completa, com informações de custo e consumo de insumos durante sua produção. Isto mostra mais uma vez que a transmissão de informação é fundamental para a aplicação plena do conceito de Ecologia Industrial. Para suprir necessidade de transmissão de dados entre as empresas e garantir a consistência e confidencialidade das informações, o BSC pode ser transmitido via web, assim o MRP 
pode listar a necessidade de materiais considerando toda a cadeia e interligando os dados mestres de materiais. Portanto ficam explícitos quais co-produtos que cada indústria tem a fornecer, forma-se então o ecossistema industrial através da Tecnologia da Informação, como será descrito neste capítulo, nos estudos de caso.

De qualquer maneira, a reciclagem utilizando os dados de apenas uma empresa permite uma avaliação semelhante à feita para a desmaterialização, ou seja, considerando a etapa anterior e posterior à que está ocorrendo no empreendimento.

A Figura 3.5 sumaria, em diagrama de blocos, como os dados de materiais são extraídos do sistema de maneira a comprovar a reciclagem de materiais. Nos dados mestres de materiais há um campo que se refere ao tipo de material utilizado e por customização foi criado o tipo "material reciclado". Toda vez que o MRP é rodado e se inicia um processo de compra de um material deste tipo, conforme os requisitos do LCI (life cicle invetory), como proposto pela EI (Ecologia Industrial), o balanço de massas e o levantamento de todos os componentes deste material ou equipamento são feitos. Estes dados alimentam os relatórios do BW (Business Warehouse) através de infocubos, que por sua vez estruturam os indicadores do Balance Scorecard referentes ao uso de materiais reciclados. Os indicadores demonstrados pelo BSC (Balance Scorecard) permitem uma AIA (análise do impacto ambiental). Com a análise do impacto ambiental destes materiais o sistema se retroalimenta.

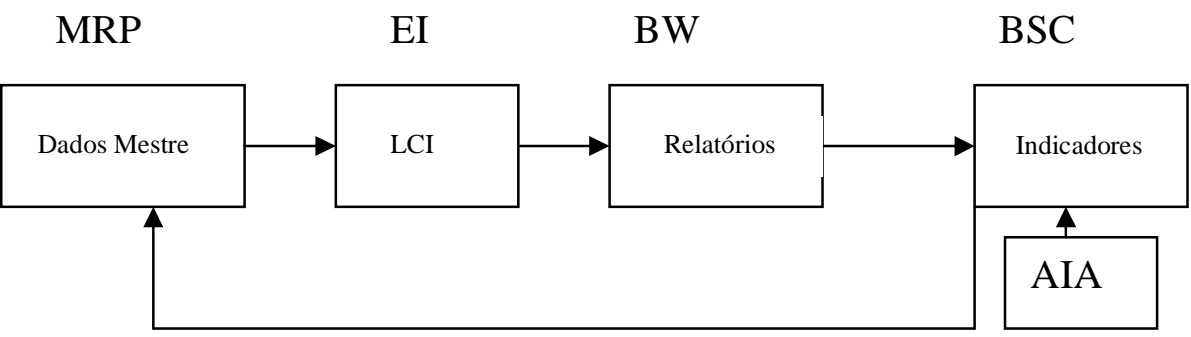

Figura 3.5 Extração de informações referentes à reciclagem para formação do BSC. Sendo:MRP (Material Resource Planning), EI (Ecologia Industrial), LCI (Life Cycle Analyses), BW (Business Warehouse), BW (Business Warehouse), BSC (Balance Scorecard), AIA (Análise de Impacto Ambiental). 
O uso do software SAP R/3 para avaliação do ciclo de vida já está definido na bibliografia (HENDRICKSON, 2001). Portanto, apenas algumas considerações serão feitas aqui. Os seguintes conceitos/definições sobre a ACV, de importância determinante para a aplicação do conceito de Ecologia Industrial, também estão presentes no SAP R/3:

a) Ambiente: meio que envolve as operações da organização (empresa, atividade) analisada.

b) Impacto ambiental: qualquer mudança no ambiente, adversa ou benéfica, resultante de atividades ou produtos da organização.

c) Intervenções: são os inputs ambientais (recursos) utilizados pelo sistema de produção; os outputs ambientais produzidos pelo sistema (emissões para o ar, água e solo), bem como as relações ambientais que não estão diretamente relacionadas com os inputs ou outputs, tais como: uso do solo; impactos físicos; aspectos relativos à saúde ocupacional; bem-estar de trabalhadores; bem-estar de animais domésticos (no caso de atividades agropecuárias), entre outros.

d) Produto: é um bem físico ou serviço que cumpre uma ou mais funções definidas.

e) Sistema de produção: é o conjunto, material ou energético, de processos unitários (unit processes) conectados, que oferece (produz) um ou mais produtos. Num sistema de produção, um processo unitário é o menor nível para a coleta de dados.

As quatro fases principais da ACV podem ser acessadas via este software. As fases em questão correspondem a: a) definição do objetivo e do âmbito (escopo) do estudo; b) inventário dos processos envolvidos, com a enumeração das entradas e saídas do sistema e determinação dos impactos ambientais associados às entradas e às saídas do sistema; d) interpretação dos resultados das fases de inventário e avaliação, considerando os objetivos do estudo. O procedimento mais simples para a alocação consiste em baseá-la nos preços relativos de cada produto no ponto da cadeia em que os produtos são separados (ponto de divisão). A idéia embutida nessa alocação econômica do produto é que a motivação atual para a produção - e, por meio disso, das intervenções ambientais é o valor econômico dos produtos. Outra estratégia consiste em realizar a alocação com base no peso (massa) dos produtos, esta foi a estratégia adotada pela facilidade que o software SAP R/3 têm em levantar os materiais usados nas etapas de produção com a 
referente massa. Os parâmetros ambientais que serão incluídos no estudo dependerão do seu peso final na fase de determinação dos impactos ambientais. Para isso, é útil a realização de uma análise de custo/benefício, relacionando o custo para a coleta de informações ao peso na determinação do impacto ambiental final. A estruturação da fase de inventário vai depender da estratégia utilizada na coleta de informações. Sugere-se, então, que a coleta de dados seja precedida da avaliação da importância de cada dado e esta deve também descrever a qualidade dos dados.

Portanto, o acompanhamento do ciclo de vida dos produtos o software em questão é feito prioritariamente pelo balanço de massa, pois no software fornece as entradas e saídas de materiais, através do que é denominado dados mestres de materiais. A Tabela 3.4 demonstra quais dados do sistema de ERP selecionado podem ser utilizados para o Life Cicle Inventory, segundo Hendrickson (2001). Estes dados podem ser usados para construir uma matriz para ACV simplificado, como abordado no capítulo 1. Neste trabalho, a maioria destes dados também foi intrinsecamente utilizada nos itens desmaterialização e reciclagem. Portanto, os dados contidos no SAP R/3 permitem a construção de uma das fases mais críticas construção do ACV, o LCI, contudo o sistema deve ser customizado corretamente para fornecê-los. Assim, se a customização gerar relatórios, via sistema de Data Warehouse e BW, estes possivelmente serão disponibilizados on-line e atenderão a uma das exigências de Ecologia Industrial: facilidade de troca de informações. Neste trabalho, desmaterialização e reciclagem serão abordadas conjuntamente, mas para atender às exigências do metabolismo industrial

Tabela 3.4 Dados do sistema de ERP a serem usados no LCI

\begin{tabular}{|c|c|}
\hline Dados do SAP R/3 & $\begin{array}{c}\text { Parâmetros necessários } \\
\text { para LCI }\end{array}$ \\
\hline
\end{tabular}




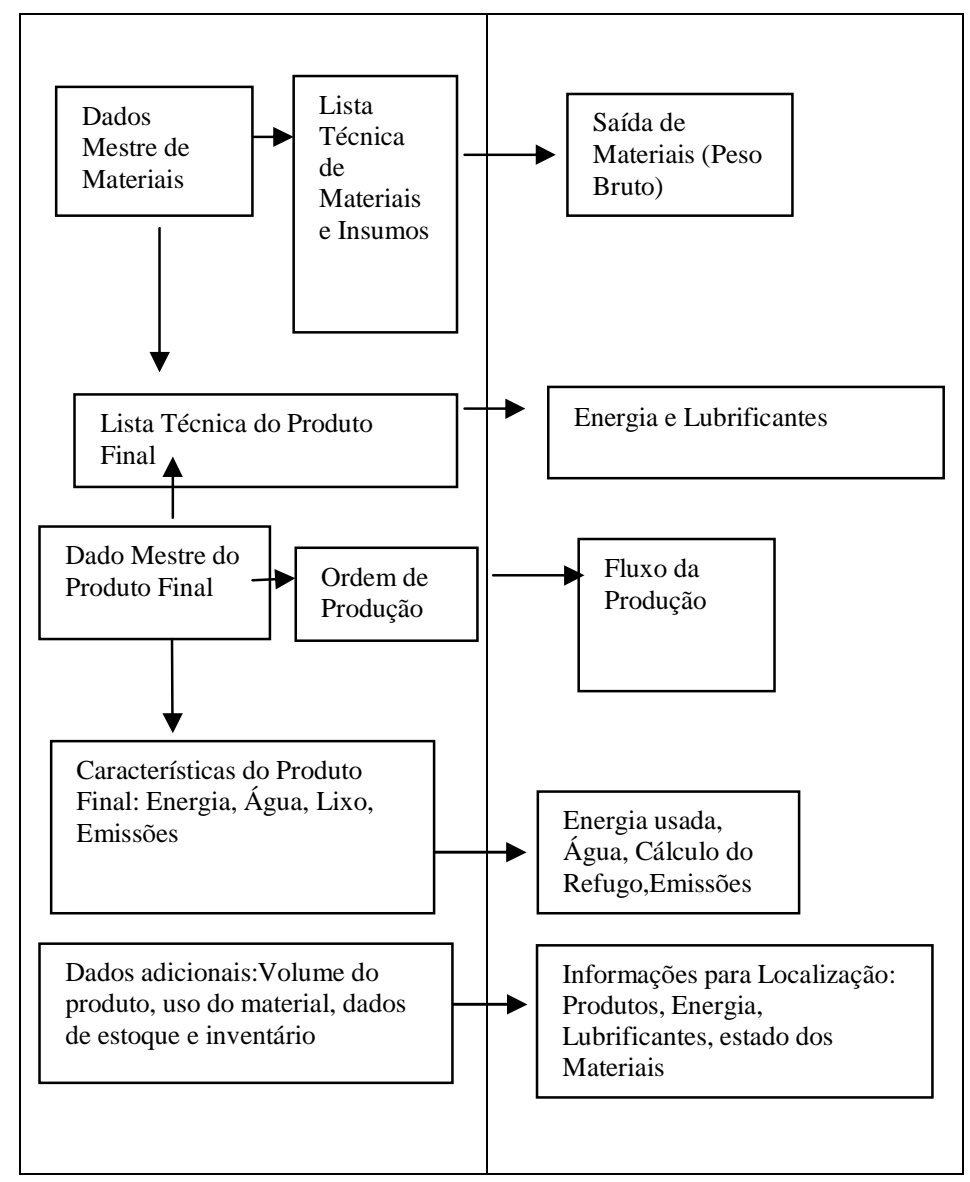

\subsubsection{Ecossistemas Industriais}

A formação de ecossistemas industriais tem como objetivo unir várias empresas de modo que os co-produtos de uma tornem-se matéria-prima de outra. Para a implantação de um ecossistema industrial não há necessidade de que os empreendimentos estejam fisicamente próximos, porém uma série de precauções devem ser tomadas para garantir a rápida troca de insumos, por exemplo com tecnologia de informação instaladas, acordos e parcerias firmados, etc.

O parâmetro crítico para a implantação de ecossistemas industriais é a possibilidade de correlação entre empresas e este dado pode ser obtido pelo SAP R/3 nas ordens de compras e vendas, incluindo a localização e a disponibilidade do co-produto. Contudo, a definição de co-produto deve ser corretamente customizada no software, como abordado anteriormente. Salienta-se novamente, que a uniformização dos dados obtidos é 
fundamental para a possibilidade de rápida avaliação do sistema, como pressupõe a Ecologia Industrial. Esta análise será melhor detalhada através de um estudo de caso de uma associação pertencente ao setor de eletroeletrônicos.

\subsubsection{Produção Limpa}

Como mostrado na introdução teórica, a Produção Limpa em geral não é considerada apenas como princípios, pois que cada princípio pode ser associado com ferramentas, tais como avaliações ambientais, etc. Portanto, muitas das propostas descritas como ferramentas para a Ecologia Industrial são também consideradas ferramentas da Produção Limpa. Assim, a maior divergência, encontra-se na geração deliberada de co-produtos, que é aceita pela Ecologia Industrial, mas não pela Produção Limpa. Além disso a Produção Limpa tem como premissas fundamentais:

* Visão sistêmica do processo;

* Aplicação de princípios fundamentais (precaução, prevenção);

* Direito de saber.

A descrição anterior dos indicadores a serem obtidos pelo software é adequada também para cumprir as determinações das ferramentas sugeridas pela Produção Limpa e Mais Limpa. Porém, as premissas fundamentais devem ser implantadas pelo estabelecimento de controles "sim/não". Um exemplo de como implantar tais controles é pela resposta aos indicadores da Produção Limpa, de acordo com o proposto pela Fundação Vanzolini (REBIA, 2007) e o Anexo 6 lista tais indicadores. De modo geral os indicadores encontram-se no formato auditoria, porém, deve-se observar, muitos desses indicadores pressupõem a obtenção de informações previamente à auditoria, informações estas muito semelhantes às discutidas no Anexo 1, e devem ser customizadas de acordo com o empreendimento avaliado. Do mesmo modo, o direito de saber, que corresponde a uma informação sobre descarte para o meio ambiente, deve respeitar recomendações e diretrizes específicas. Por exemplo, nos EUA o direito de saber é garantido através da publicação anual do Toxic release inventory, onde todas as empresas listam suas emissões anuais. Este "inventário" também é útil para avaliar a evolução histórica das empresas e/ou setores produtivos. 
Controles como os necessários a esse item são comuns no módulo Quality Management do software. Esse módulo também é útil para implantação de normas, como as da série ISO. Contudo, todas estas hipóteses só podem ser levantadas se indicadores objetivos são obtidos. Portanto, para a verificação do cumprimento destas premissas, um processo claro de auditoria, provavelmente baseado na geração de relatórios, faz-se necessário.

Por fim, espera-se que a visão sistêmica do processo seja obtida considerando-se o tripé de sustentabilidade, ou seja, obtendo-se não só indicadores ambientais e econômicos, como também sociais. Indicadores econômicos e sociais serão discutidos posteriormente.

\subsubsection{Contabilidade Ambiental}

A contabilidade ambiental pode ser entendida no contexto da avaliação do custo total. Esta avaliação pressupõe a avaliação de todos os custos, mesmo os mais indiretos como formação de imagem negativa da empresa. Neste particular aspecto ainda há muita controvérsia sobre como melhor aplicar o conceito, muito embora já existam softwares sugeridos para isso e indicadores propostos pela UNEP, etc. (BEBBINGTON, 2001).

O sistema SAP R/3 possui funcionalidades que disponibilizam dados necessários para que seja feita uma contabilidade ambiental restrita, porém levando-se em conta diferentes indicadores, inclusive sociais. Assim, o custo de um produto é facilmente calculado a partir dos dados mestres do material e do módulo de recursos humanos e seu preço a partir do módulo de finanças, que descreve aspectos econômicos da empresa. Custos indiretos simples, como aqueles envolvidos nas teorias de qualidade e detectáveis através da implantação de normas de qualidade, por exemplo tempo de parada para setup de máquina, também são facilmente determinados. Porém, custos menos objetivos, para serem calculados necessitam da customização do software em relação a restrições específicas e adição de valoração a essa restrição, o que não é simples.

Neste texto será abordado posteriormente um estudo de caso para avaliar o aspecto econômico de variações técnicas em uma empresa e outro para analisar a questão social. 


\subsubsection{Normas ambientais, econômicas e sociais}

A sustentabilidade pressupõe que aspectos técnicos, como a qualidade, e econômicos além de meio ambiente e responsabilidade social sejam completamente integrados. Assim, normas foram criadas e, muita delas como as da série ISO, têm aceite mundial.

A questão econômica foi discutida anteriormente. Com a padronização de aspectos técnicos por uma norma, como a ISO 9000, o sistema SAP R/3 pode efetuar o controle do cumprimento dos requisitos desta, como mencionado anteriormente para outros tópicos, mas para isto é necessária a customização do módulo de QM (Quality Management). Porém a customização das entradas de materiais e o andamento dos processos só serão possíveis após a verificação dos requisitos. Por exemplo, o controle da tolerância dimensional conforme a norma pode ser garantido pelo sistema que garantirá menor geração de refugos, portanto prevenção de poluição.

A responsabilidade social pode ser analisada sob dois aspectos distintos, o interno e o externo. A análise interna leva em conta a saúde e segurança no trabalho e pode ser avaliada pelo ISO 18000; enquanto esta ainda não está completamente definida pode-se utilizar similares como a BS 8800. Essa normalização é simples, como comentado anteriormente, e não foi objeto de estudo deste trabalho. Pelo aspecto externo pode-se utilizar normas de sustentabilidade como a SA 8000. Esse trabalho utilizar-se-á apenas da análise externa para definição de indicadores e considerará a aplicação da norma SA 8000. Contudo, devido às restrições dessa norma, muitas informações de saúde e segurança, como as esperadas na BS 8800, são obtidas.

Os indicadores sociais escolhidos estão de acordo com os padrões definidos pelo IBES (Instituto Betinho de Sustentabilidade), devido à grande abrangência destes e o Anexo 7 apresenta uma proposta de balanço social feita por esta entidade. Para comparação com outros requisitos de outras entidades, esses indicadores foram também listados no Anexo 1. 
Os indicadores escolhidos podem ser avaliados pelo software utilizando um módulo conhecido como HR (Human resources) e a Figura 3.6 mostra as sucessivas telas que rastreiam indicadores constantes no Anexo 7. Como exemplo de indicador social tem-se a capacitação e desenvolvimento profissional (Figura 3.6.a). O acesso à educação como índice social externo é demonstrado no relatório gerado pela transação rastreada na tela da Figura 3.6.a, como demonstrado na Figura 3.6.b. Uma análise demográfica do corpo funcional pode ser feita pelo módulo de HR pelo relatório da transação mostrado na Figura 3.6.c. Até mesmo o número de portadores de deficiência pode ser levantado, como mostra a Figura 3.6.d.

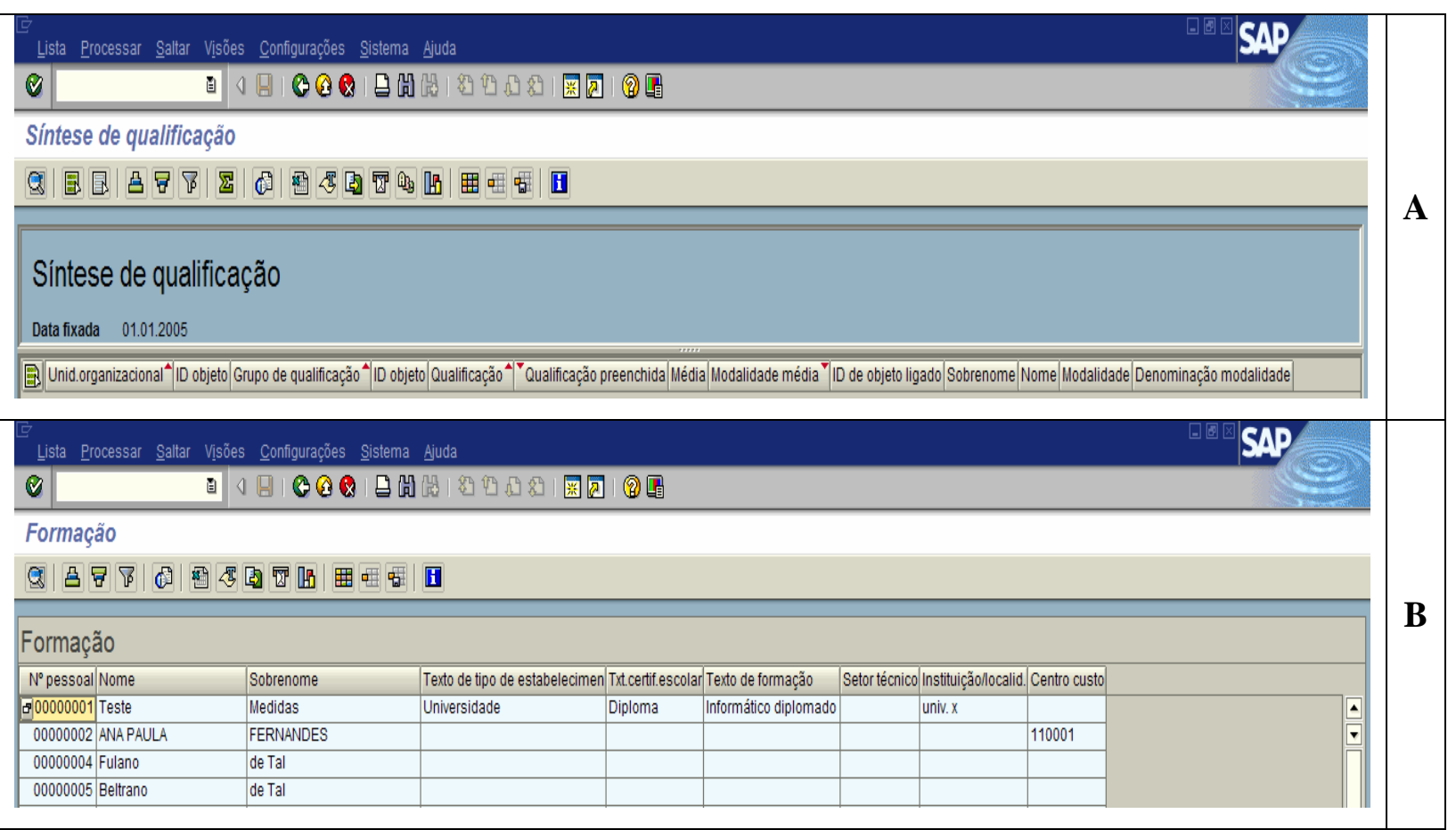

Figura 3.6 Exemplo de rastreabilidade de indicador social (capacitação e desenvolvimento profissional), de acordo com o proposto pelo IBES: a Indicador social interno - Capacitação e Desenvolvimento.; b, Indicador social externo formação dos empregados; 


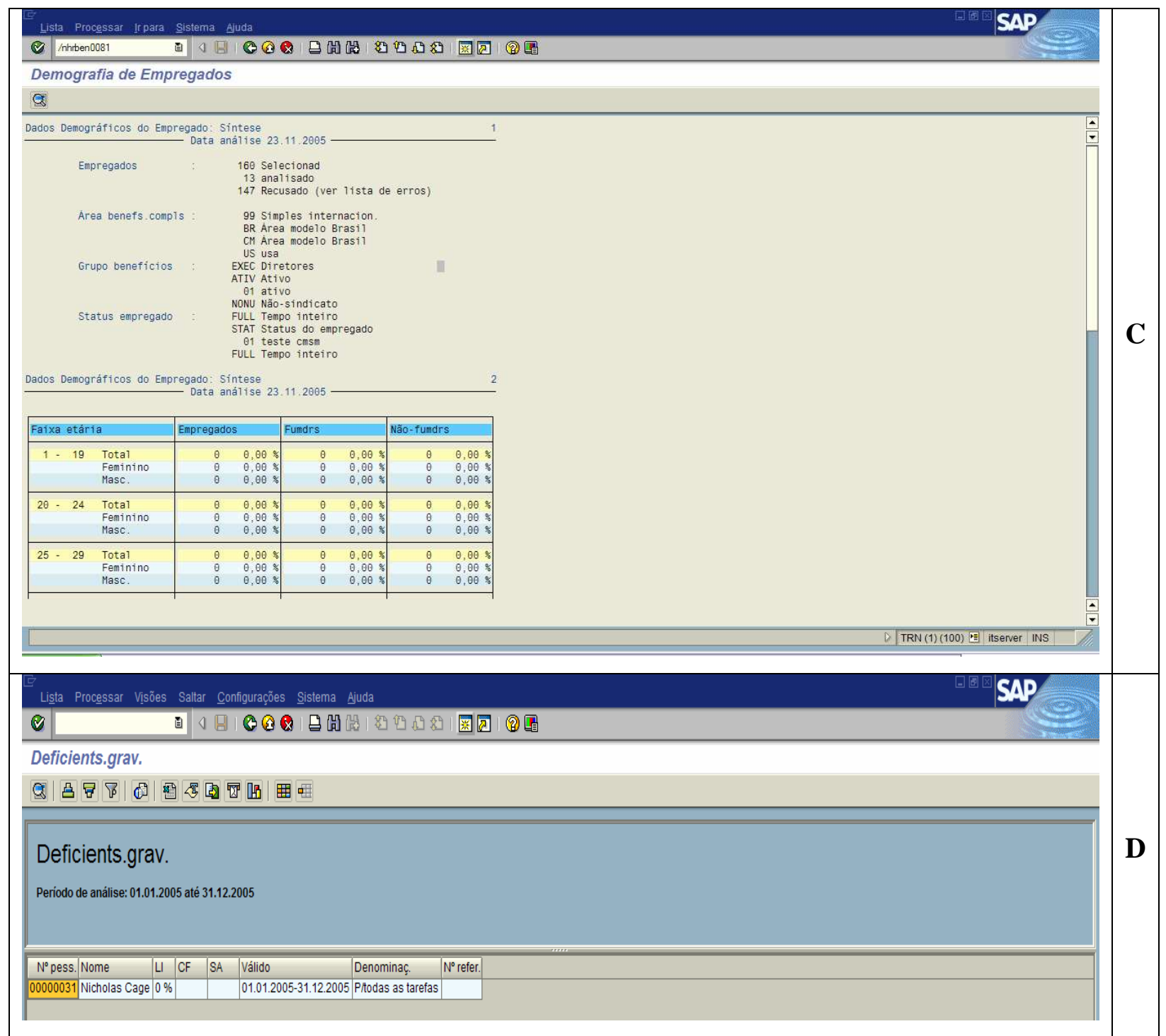

Figura 3.6 Exemplo de rastreabilidade de indicador social (capacitação e desenvolvimento profissional), de acordo com o proposto pelo IBES: c, Indicador social do corpo funcional - análise demográfica; $d$ indicadores do corpo funcional - número de deficientes e quais limitações

Novamente, estes dados alimentam infocubos para geração de relatórios integrados pelo sistema de Business Warehouse, que por sua vez pode validar indicadores para os Key Performance Indicators, como indicado na Figura 3.7. 


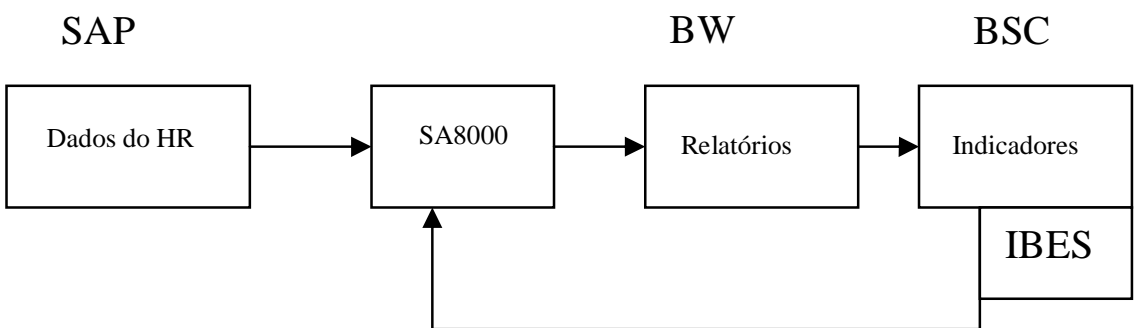

Figura 3.7 Extração de dados referentes à Responsabilidade Social. Sendo HR (Human Resources), BW (Business Warehouse), BSC (Balance Socorecards) e IBES (Instituto Betinho de Sustentabilidade)

\subsubsection{Conclusão Parcial}

A implantação do conceito de Ecologia Industrial em uma empresa através do software SAP mostrou-se não só possível como também vantajosa em inúmeros aspectos. A Tabela 3.5 mostra a correlação entre os dados possíveis de se obter com pouca ou nenhuma customização e os compara com os macro indicadores listados no Anexo 1. Observe-se que o atendimento às questões ambientais, econômicas e sociais está de acordo com o tripé de sustentabilidade:

- A maioria dos indicadores de caráter ambiental pode ser obtida imediatamente, ou exigem customização relativamente simples de ocorrer pelo estabelecimento de restrições, durante a formação de um subsistema com os dados mestres dos materiais. Assim, as necessidades de controle ficam bastante simplificadas para avaliação das potencialidades do referido subsistema. Neste trabalho, estudo referente à implantação de ecossistemas industriais faz amplo uso desta concepção.

- Os aspectos econômicos são mais difíceis de analisar, contudo, como dependem muitas vezes de restrições que foram customizadas, podem ser avaliados por auditorias. Assim, se os dados estiverem rapidamente disponíveis para produção de relatórios, tem-se maior agilidade e ganho econômico. Neste trabalho, um estudo de caso aborda o uso de relatórios em auditorias.

- Indicadores sociais estão amplamente disponíveis no módulo de recursos humanos e, neste trabalho, um estudo de caso de produção de relatório para o balanço social é demonstrado. 
Tabela 3.5 Resumo da correlação entre indicadores de sustentabilidade e as atendimento pelas funcionalidades do software.

\begin{tabular}{|c|c|l|}
\hline Tripé & $\begin{array}{c}\text { Percentual médio de } \\
\text { atendimento via o SAP R/3 }\end{array}$ & \multicolumn{1}{|c|}{ Indicador } \\
\hline Econômico & $70 \%$ & $\begin{array}{l}\text { Balanço Financeiro } \\
\text { BOVESPA }\end{array}$ \\
\hline Social & $75 \%$ & SA 8000 \\
\hline Ambiental & $70 \%$ & $\begin{array}{l}\text { Ecologia Industrial, } \\
\text { BOVESPA e } \\
\text { CEBDS }\end{array}$ \\
\hline
\end{tabular}

O procedimento proposto, e usado neste trabalho para a utilização das referidas funcionalidades do software é demonstrado na Figura 3.8. O gráfico de Ishikawa mostra o processo de avaliação da Ecologia Industrial via indicadores denominados EPI's (Environmental Performance Indicators), estes foram apresentados na forma de BSC, para uma identificação visual simplificada.

Os dados do sistema (imobilizado, Figura 3.8) são repassados para tabelas internas que alimentam info objetos (PEP, Programming Environment Based on Petri Nets, Figura 3.8). Os info objetos podem ser considerados como pequenos cubos de dados que podem ser selecionados para formar um info cubo.

A geração de um info cubo é feita pelo Business Warehouse, um cubo de dados pode gerar um relatório flexível, pois neste estão todas as informações do sistema organizadas em info objetos que podem ser rastreados da maneira que o usuário necessitar. O info cubo pode se tornar transacional, isto quer dizer que ele é alimentado constantemente com dados atualizados. Neste trabalho dados de materiais (material, Figura 3.8) e informações semelhantes ao inventário de ciclo de vida (LCI, Figura 3.8) fornecem os parâmetros necessários ao info cubo.

Por outro lado, a adaptação para uso em avaliação de sistemas com o conceito de Ecologia Industrial pode ser feita mais facilmente se os dados forem apresentados e/ou manipulados, o que pode ser obtido pelo uso de um Balance Scorecards (BSC). 
Os cubos transacionais podem ser usados como fonte de dados para validar indicadores usados no BSC para avaliar a sustentabilidade. $\mathrm{O}$ cubo alimenta o indicador gerando uma massa de dados de simples compreensão. Esses dados formam a matriz de indicadores (AIA, Figura 3.8).

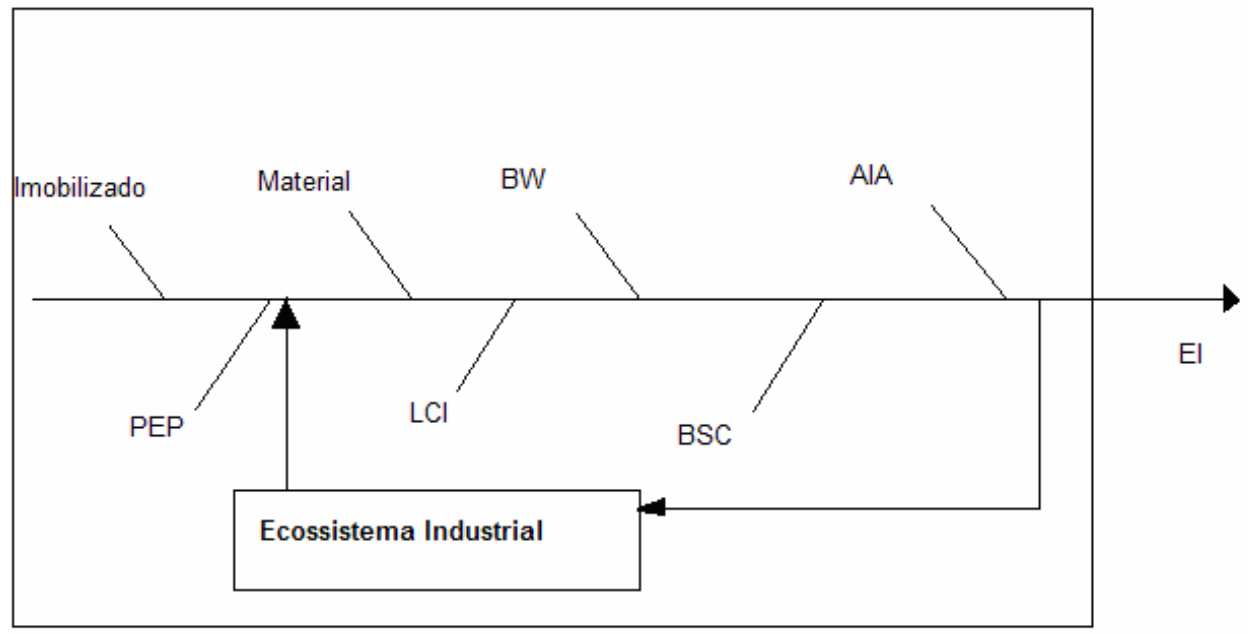

Figura 3.8 Exemplo de um processo de ecologia industrial. Sendo: PEP (Programming Environment Based on Petri Nets), LCI (Life Cycle Analyses), BW (Business Warehouse), BSC (Business Warehouse), AIA (Análise do Impacto Ambiental) e EI (Ecologia Industrial).

Para validar o procedimento descrito na Figura 3.8, simulou-se, a partir de dados reais de uma empresa de distribuição de energia, a quantidade de cobre que é consumida e descartada durante a construção de uma torre de transmissão (Imobilizado). O PEP descreve várias etapas da construção da obra. Para cada etapa, buscou-se (Material) quanto cobre foi adquirido. Como o Imobilizado descreve a composição final do produto, comparou-se o valor de aquisição com o restante na obra e verificou-se qual a perda do processo. Obtendo-se (via Material) a destinação do cobre não utilizado avaliou-se como esse foi descartado, no presente caso na forma de sucata. Este pequeno balanço de massa permitiu obter um indicador importante (eficiência do processo), mas também comprovar a existência ou não de um ecossistema industrial. Observou-se que aproximadamente $25 \%$ do cobre é descartado na construção, $90 \%$ deste é vendido como sucata.

\subsection{Estudos de caso}




\subsubsection{Introdução}

O levantamento de dados para a caracterização do setor de eletroeletrônicos permite verificar se o conceito da Ecologia Industrial pode ser aplicado neste setor via software e também facilita a obtenção de índices de sustentabilidade. A aquisição de dados para a obtenção destes índices foi feita de três maneiras distintas: a) por pesquisa de informação acadêmica, ou seja, pesquisando teses e artigos para verificar quais eram os dados disponíveis. O levantamento de dados acadêmicos não só permite comparação entre as condições do país e do exterior, com provável generalização dos resultados, como também pode ser usado nos próprios estudos de caso; b) em questionários diretos ou indiretos com representantes do setor de eletroeletrônicos e via associações; c) diretamente por contato com empresas e/ou por simulações.

Os estudos de caso seguiram a ordem do gráfico de Ishikawa, apresentado na introdução deste trabalho e reproduzido novamente na Figura 3.9, que descreve simplificadamente a cadeia de produção do setor. Estudos de casos foram feitos em cada etapa priorizando os fatores críticos encontrados para de cada uma destas. No final da cadeia demonstraram ser mais relevantes, como serão abordados mais tarde, os parâmetros como logística e os indicadores econômicos. Por fim, dada à relevância dos aspectos sociais estes serão tratados separadamente, sem contudo corresponder a uma parte específica da cadeia de produção de eletroeletrônicos.

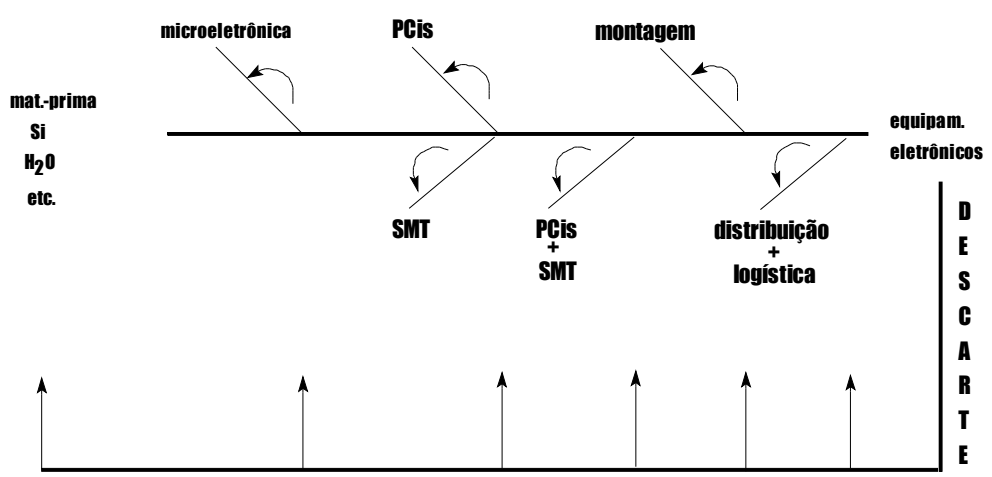

Figura 3.9 Gráfico de Ishikawa da produção no setor eletroeletrônico. As flechas indicam possibilidades de montagem de ecossistemas industriais internos ou externos (PCI - placa de circuito impresso, SMT - surface mounting technology). (SILVA, 2004) 


\subsubsection{Produção de matéria-prima}

A produção dos insumos básicos para o setor de eletroeletrônicos normalmente não é considerada dentro da cadeia; porém, algumas considerações serão feitas neste trabalho pelos seguintes motivos:

- Devido ao alto consumo de eletroeletrônicos, a produção de insumos pode ser caracterizada como produtor primário. Assim, muito embora haja uma grande variação nos produtos do setor eletroeletrônico, de modo geral a sucata, normalmente denominada de lixo eletrônico (Electronic waste, E-waste), tem composição média de 40:30:30 de metal, material plástico e óxidos refratários, respectivamente (SODHI, 2001). A composição dos eletroeletrônicos, apesar de muito variada, é altamente dependente do uso de silício (ZUFFO, 2003). O silício, por sua vez, é alvo de estudo da ONU desde o início da década de 90, no programa intitulado "Quartz Industrial Trade System" - QITS. Este programa tem por objetivo caracterizar a área quartzobiomassa-silício, da extração até a produção de produtos de alta tecnologia e possui representantes brasileiros.

- Outro possível produtor primário nesta área - material plástico - encontra-se numa cadeia de produção de insumos advindos da área petroquímica, onde o país tem tradição reconhecida.

- Por fim, os metais são provavelmente o melhor dos produtores primários, devido ao alto volume produzido e grande pureza além da existência de materiais raros (SODHI, 2001), e apresentam processos de produção muito semelhantes aos do silício.

\subsubsection{A produção de silício}

O programa QITS, na década de 90 gerou um livro que tenta descrever, ao menos qualitativamente, o ciclo de vida dos eletroeletrônicos (QITS, 1998). Também produziu vários encontros e/ou publicações (NAKAYAMA, 1998), (WILLIAMS, 1999) (ZANDERSONS, 1999), (ZANDERSONS,2000) e, ao seu término, uma pequena revisão (SUZUKI, 2000), sumariada a seguir. 
O programa QITS teve como objetivo "identificar e propor soluções alternativas às questões ambientais, sociais, econômicas e tecnológicas deste vasto e complexo sistema integrado quartzo-biomassa-silício". Em 2000 "a produção mundial de silício metálico era de aproximadamente 1 milhão de t/ano, a maioria utilizada para química fina, microeletrônica e ligas especiais... Os maiores produtores no mundo são Brasil, Estados Unidos, China e Noruega...”. O Brasil, numa eventual explosão de consumo, é capaz de suprir a demanda de quartzo por apenas 15 anos. Um dos co-produtos de maior impacto ambiental na produção de silício é o $\mathrm{CO} 2$, com "uma proporção de 4,2 $\mathrm{Kg}$ de $\mathrm{CO} 2$ por kg de silício produzido". Outros possíveis co-produtos e/ou resíduos também foram determinados e a Tabela 3.6 os resume. Na Tabela, a definição de resíduo ou co-produto é utilizada de acordo com o descrito no capítulo 1. É importante observar que propostas de diminuição da formação de resíduos foram feitas dentro do projeto e serão discutidas posteriormente.

Tabela 3.6 possíveis co-produtos e/ou resíduos da produção de silício grau metalúrgico, de acordo com pesquisas realizadas no projeto QITS (informações obtidas de SUZUKI, 2000).

\begin{tabular}{|c|l|}
\hline Matéria-prima & \multicolumn{1}{|c|}{ Coproduto e/ou resíudo } \\
\hline Quartzo & \multicolumn{1}{|c|}{ CO/CO2 (resíduo) } \\
\hline Carvão mineral & \multicolumn{1}{|c|}{ SOx (resíduo), CO/CO2 (resíduo) } \\
\hline \multirow{2}{*}{ Carvão vegetal } & $\begin{array}{l}\text { CO/CO2 (considerado removido por } \\
\text { seqüestro quando do crescimento das plantas, } \\
\text { de acordo com balanço de massa), porém } \\
\text { induz a monocultura }\end{array}$ \\
\cline { 2 - 3 } & $\begin{array}{l}15 \% \text { de rejeitos dos finos de Carvão vegetal } \\
\text { (co-produto) }\end{array}$ \\
\hline Rejeitos de lascas de quartzo natural & $\sim 15 \%$ do quartzo extraído (co-produto) \\
\hline Oxigênio e nitrogênio para refino & $\begin{array}{l}\sim 7 \% \text { de escórias do total de silício produzido } \\
\text { (co-produto) }\end{array}$ \\
\hline Baixa eficiência elétrica nos fornos & \multicolumn{1}{|c|}{$\sim 30 \%$ de aproveitamento de energia } \\
\hline
\end{tabular}

De acordo com os valores obtidos e as conclusões, mostradas na Tabela 3.6, do programa QITS é provável a formação de ecossistemas industriais devido ao alto volume produzido. O processamento de silício é semelhante ao usado para produção de vários metais, entre eles o ferro. Neste particular aspecto, o CEBDS (CEBDS, 2001) tem experiência na implantação de ecossistemas industriais, principalmente com a formação do Ecopolo Rio, como comentado nos aspectos teóricos deste trabalho. Assim, várias das 
parcerias propostas para o Ecopolo provavelmente poderiam ser utilizadas nesta área da cadeia de produção. O alto volume também impõe a necessidade de que as parcerias ocorram entre empreendimentos fisicamente próximos.

Por fim, como comentado anteriormente, o programa QITS também propôs processos de diminuição da formação de resíduo e a Tabela 3.7 apresenta as alternativas propostas para diminuir a emissão nessa área da cadeia produtiva e a avaliação sobre qual ferramenta de Ecologia Industrial ou Produção Limpa utilizou-se para compor a proposta. De modo geral essas propostas encontram-se em fase laboratorial, mas já se pode notar uma tendência de propor uma parceria entre setores distintos de produção: sucroalcooleira e silício.

Tabela 3.7 Alternativas propostas pelo projeto QITS para diminuir a emissão na produção de silício (informações obtidas de SUZUKI, 2000).

\begin{tabular}{|l|l|}
\hline \multicolumn{1}{|c|}{ Proposta } & \multicolumn{1}{|c|}{ Avaliação da proposta } \\
\hline $\begin{array}{l}\text { Substituição do carvão vegetal por bagaço } \\
\text { de cana }\end{array}$ & $\begin{array}{l}\text { Formação incipiente de ecossistema } \\
\text { industrial }\end{array}$ \\
\hline Redução de quartzo com tocha de plasma & $\begin{array}{l}\text { Aplicação de tecnologia limpa e prevenção } \\
\text { de poluição por diminuição do consumo de } \\
\text { energia elétrica }\end{array}$ \\
\hline $\begin{array}{l}\text { Lascas de quartzo com tecnologia } \\
\text { ambientalmente amigável (quench-leach) }\end{array}$ & $\begin{array}{l}\text { Aplicação de tecnologia mais limpa e } \\
\text { prevenção de poluição }\end{array}$ \\
\hline
\end{tabular}

Como a produção de silício a partir dessa matéria-prima alternativa, pelo aspecto de impacto ambiental, já foi avaliada (SUZUKI, 2000), resta verificar como a queima e o transporte do produto até o local de consumo interage na cadeia. Estudos brasileiros sobre o ciclo de vida da cana-de-açúcar mostraram que " 145,3 toneladas de $\mathrm{CO}_{2} /$ hectare/ciclo são seqüestradas no cultivo da cana-de-açúcar e 111,5 toneladas de $\mathrm{CO}_{2} /$ hectare/ciclo são emitidas na co-geração de eletricidade excedente, resultando no saldo favorável de seqüestro de $\mathrm{CO}_{2}$ de 33,8 toneladas/hectare/ciclo de vida de eletricidade excedente, 
quantia que é fornecida às empresas de distribuição de energia." E que "ao se comparar com outras formas de geração de eletricidade, a energia produzida em usinas de álcool e açúcar apresenta os mais baixos valores de emissão de $\mathrm{CO}_{2}$ ” (MORETON, 2004). Assim, torna-se relevante o transporte da matéria-prima até o ponto de consumo, para que não se crie emissão significativa de $\mathrm{CO}_{2}$.

Estudos brasileiros (MATTOS, 2001) sobre emissões por transporte de carga mostram uma emissão de $2.10^{5} ; 1.10^{5}$ e $1.10^{4} \mathrm{gCO}_{2} /$ tonelada-quilometro quando se utiliza caminhão, trem ou navegação marítima, respectivamente. Portanto, o sistema de controle (BSC) deve considerar bastante relevante a distância entre os dois produtores primários: bagaço de cana/silício.

Em empresas que utilizam um sistema de ERP, normalmente encontra-se um módulo denominado LSI (Logistical System Information), este considera todos os parâmetros previamente configurados e propõe o caminho ótimo para o transporte, incluindo via e roteiro. No caso deste módulo não estar configurado necessita-se, para a geração do BSC, das condições envolvidas no transporte. Condições são todos os parâmetros relevantes, como custos de fretes e seguros. Para a consideração da emissão de $\mathrm{CO}$ 2, basta a inclusão de uma nova condição dependente da distância e que calcule a emissão de acordo com os parâmetros inseridos. A avaliação das condições do transporte viabiliza ou não a comercialização do co-produto.

Independentemente do seqüestro de carbono, o uso de biomassa para produção de energia é comum no país. O Ministério de Minas e Energia (http://www.mme.gov.br/) informava em 1999 que a matriz energética brasileira era formada por consumo de 10,8\% de lenha e $12,7 \%$ de cana-de-açúcar. Contudo, o processo está intrinsecamente ligado à formação de ciclos internos - o que corresponderia a um ecossistema industrial incipiente - e, portanto, com pouco gasto e/ou emissão devido ao transporte. Deste modo, o controle de distância, pelo aspecto ambiental é ainda mais crítico. Assim, a proposta de utilização do software de controle e respectivo BSC é vantajosa para essa área, não só ambientalmente mas também para decisão econômica sobre que sistema adotar.

Portanto, como exposto na Tabela 3.7, há a necessidade de verificar o provável impacto da formação de ecossistemas industriais envolvendo silício, bagaço de cana e metalurgia e as seguintes etapas foram efetuadas neste trabalho: 
- Definição da região de produção de silício e comparação com as regiões onde se encontram empreendimentos metalúrgicos, refinarias e produção de cana;

- Procura de empreendimentos metalúrgicos que utilizassem a concepção de Ecologia Industrial, ou pelo menos de formação de ecossistemas industriais, mesmo que tal proposta não estivesse explicita no discurso da empresa;

- Para a empresa em questão, verificação da existência de software de controle e o seu modelo.

- Avaliação de possíveis ecossistemas industriais existentes internamente à empresa utilizada no estudo de caso;

○ Avaliação do impacto desses ecossistemas.

- Avaliação de possíveis ecossistemas industriais externos utilizando co-produtos da produção de silício;

- Proposta de formação de ecossistemas;

○ Avaliação do impacto desses ecossistemas.

A Tabela 3.8 descreve as interações entre os sistemas. O bagaço de cana pode ser aproveitado como co-produto em todas as indústrias selecionadas para a geração de energia e o silício para a formação de liga metálica, que corresponde a dois ecossistemas industriais externos. O uso do bagaço de cana como ração animal é comum quando o empreendimento encontra-se próximo ao local de fabricação de açúcar ou álcool, formando um ecossistema aparentemente interno.

Tabela 3.8 POSSÍVEIS SIMBIOSES OBSERVADAS.

\begin{tabular}{|c|c|c|c|c|}
\hline \multirow{2}{*}{\begin{tabular}{c} 
Produtor \\
\cline { 2 - 5 } Primário*/Produto
\end{tabular}} & $\begin{array}{c}\text { Indústria } \\
\text { Extratora de } \\
\text { Silício }\end{array}$ & $\begin{array}{c}\text { Produtora de } \\
\text { cana-de- } \\
\text { açúcar }\end{array}$ & $\begin{array}{c}\text { Indústria } \\
\text { Metalúrgica }\end{array}$ & $\begin{array}{c}\text { Indústria } \\
\text { sucro- } \\
\text { alcooleira }\end{array}$ \\
\hline Bagaço de cana. & $\mathrm{x}$ & $\mathcal{X}$ & $\mathrm{X}$ & $\mathrm{X}$ \\
\hline Escórias de silício & $\mathrm{a}$ & & $\mathrm{X}$ & \\
\hline
\end{tabular}

$\mathrm{X}$ - obtenção de energia, $\mathrm{x}$ - formação de liga metálica, $\mathcal{X}$ - uso como fertilizante ou ração animal; a - uso de tecnologia limpa

No país as localidades produtoras de silício, álcool e ferro encontram-se principalmente em: 
- Silício: principalmente no Pará (63,9\%) e Minas Gerais, com 16,7\%, além de Santa Catarina, com $15 \%$, de acordo com o Departamento Nacional de Produção Mineral

- Cana de açúcar e obtenção de álcool: principalmente em São Paulo, com 70\%, de acordo com o Departamento de Agricultura.

- Metalúrgicas: dois pólos importantes, no Rio de Janeiro, com formação de ecossistema industrial, e Minas Gerais, porém São Paulo apresenta várias metalúrgicas pequenas, de acordo com o Departamento Nacional de Produção Mineral

Por outro lado, a matéria-prima a ser substituída - carvão mineral - vem principalmente do exterior (Rússia) e, em pequena escala, Santa Catarina.

Por entrevista com especialistas, como comentado anteriormente, encontrou-se a implantação do sistema de ERP SAP R/3 em uma metalúrgica, que proporcionou um aumento de $67 \%$ na destinação dos materiais no prazo de um ano. O sistema utilizado foi estudado e uma implantação semelhante foi feita para este estudo de caso e a Figura 3.10 descreve a customização necessária. A Figura 3.10a mostra o cadastro das condições de transporte, onde o custo ambiental da emissão de $\mathrm{CO}_{2}$ foi colocado como custo complementar e assim será parâmetro para a simulação e definição do caminho ótimo. A Figura $3.10 \mathrm{~b}$ demonstra a simulação de uma ordem de transporte apontando as melhores práticas para a comercialização do co-produto.

Portanto conhecendo a localização da empresa e os custos do transporte, incluído o custo ambiental, o sistema fornece o cálculo do custo total do transporte, assim pode-se comparar este com o custo do descarte, comprovando os ganhos econômicos ambientais, desta maneira o ecossistema industrial pode ser viabilizado. 


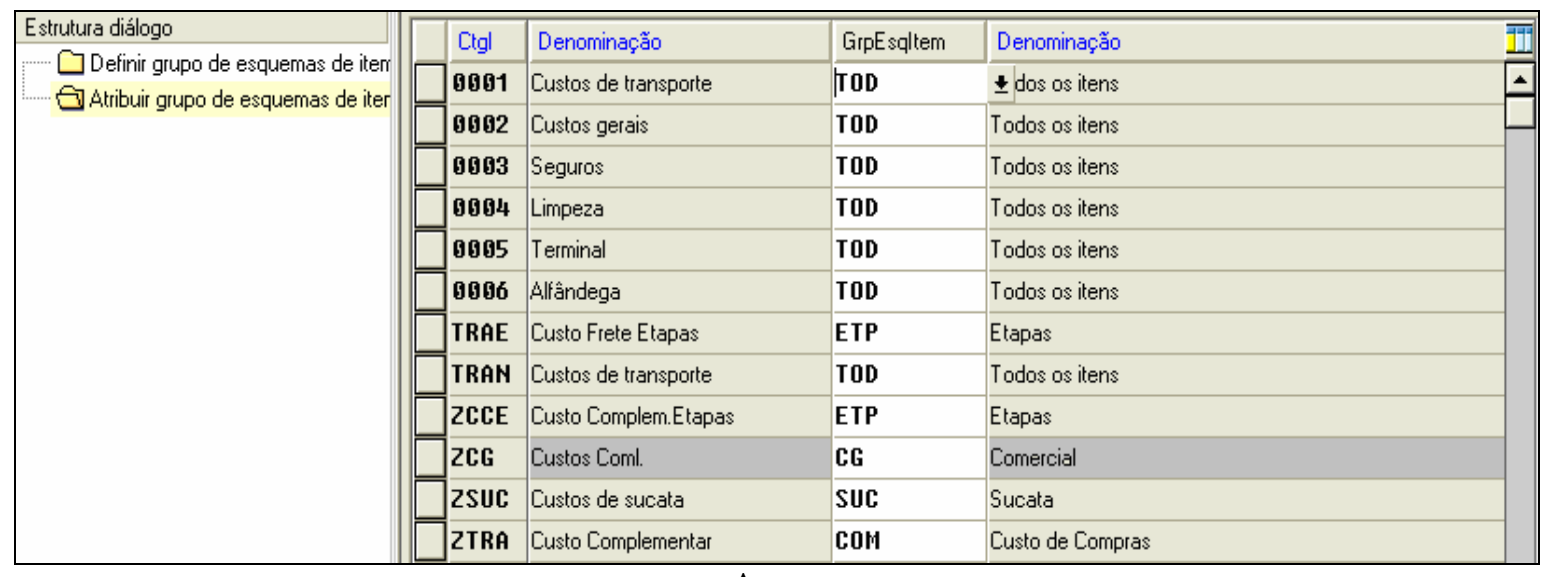

A

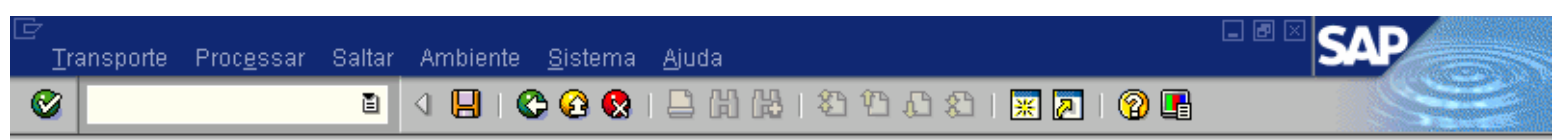

Transporte entrada \$0001 Criar: síntese

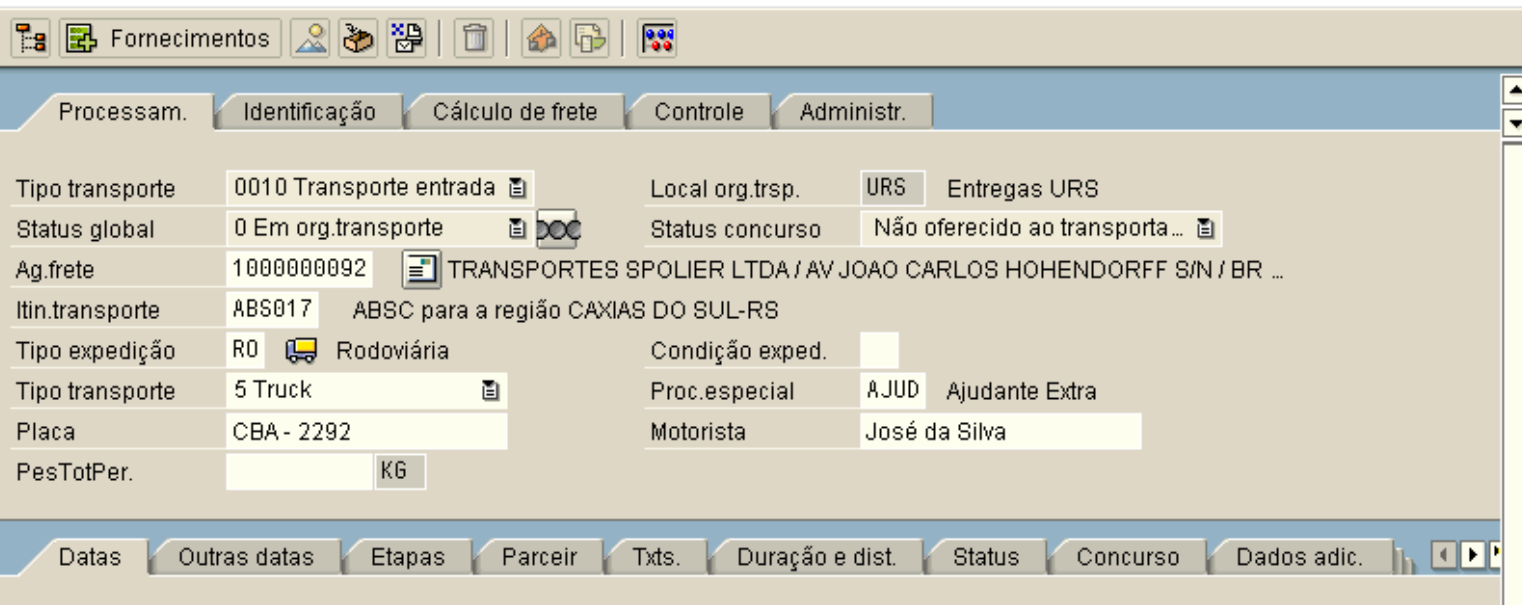

\section{B}

Figura 3.10 configuração das condições de transporte. a - cadastro das condições de transporte, b - simulação de uma ordem de transporte.

O principal fator limitante para a comercialização dos co-produtos é a distância. Portanto é necessário calcular a máxima distância que o bagaço de cana pode ser transportado antes de ocorrer emissão de $\mathrm{CO}_{2}$. Sabendo-se que a produtividade da cana de açúcar é de 60 t/ha (estimativa da FAO - Food and Agriculture Organization - para 1999), o ecossistema pode ser ambientalmente eficiente, ou neutro, quanto ao seqüestro de carbono, apenas se a distância máxima for $3 \mathrm{~km}$. Por outro lado, considerando a distância do carvão mineral atualmente importado, o sistema continua mais eficiente em termos de seqüestro de carbono para qualquer configuração. Os valores econômicos, 
porém, não podem ser avaliados porque, devido às grandes quantidades comercializadas, há interesse comercial em não disponibilizar valores, contudo, avaliação pelo valor médio também demonstrou vantagem econômica.

Muito embora a indústria de açúcar e álcool costuma utilizar o bagaço de cana em suas caldeiras, ainda é possível propor ecossistemas industriais. Como escórias da indústria do silício (KORNDORFER, 1995) e da siderúrgica (PRADO, 2002) podem ser usadas para a adubação do solo para produção de cana, uma hipótese interessante para se avaliar é a formação de um ecossistema ao lado da região produtora de silício pela adição da cadeia de açúcar e álcool. Neste aspecto, por simulação, o local mais provável de estabelecer o ecossistema é próximo ao estado de São Paulo, onde todas as empresas apresentam representantes. O ecossistema é aqui definido como indústria de processamento de silício, metalúrgica e produção de cana-de-açúcar, se possível acoplada à produção de açúcar e álcool.

\subsubsection{Produção de metais}

Sodhi (2001) lista como principais metais encontrados no setor eletroeletrônico, em ordem decrescente de peso: cobre, ferro, níquel, estanho, chumbo, alumínio, zinco, ouro, prata, paládio.

O país possui vários dos metais listados, sendo uma das maiores reservas de minério de ferro no mundo (EZEQUIEL, 2001). A mineração no país encontra-se efetuada principalmente por poucas e grandes empresas. Assim, estas podem ser produtoras primárias, tanto considerando a produção como o descarte dos produtos. Portanto, o uso do software para aplicação do conceito de Ecologia industrial pode ocorrer de modo semelhante ao estudo de caso, e metodologia, descrito anteriormente.

Contudo, para o setor precisa-se considerar o requisito pureza de cada área produtiva. Deste modo, formação de ecossistemas é mais provável, devido ao volume de produção e quantidade percentual de metais, para a área de eletrodomésticos, eletrônica de potência, etc., o que cria muitas variáveis de ordem econômica e social, principalmente quanto à regulação (normas, diretrizes, etc.). A análise destas necessidades encontra-se fora do escopo deste trabalho. 
Consulta aos principais produtores na área de eletrodomésticos não mostrou tendência à reciclagem em ciclo externo.

\subsubsection{Produção de outros insumos}

Os materiais plásticos citados como em grande porcentagem do lixo eletrônico, de modo geral correspondem ao final da cadeia de produção genericamente descrita como Química Fina. Além disso, como será abordado posteriormente, há um alto consumo de produtos químicos, via de regra de extrema pureza, em outras áreas da cadeia de produção.

No país, a Química Fina (NELSON, 2004) teve franca expansão apenas até o final da década de 80 pois, após a abertura comercial ocorrida nos anos 90 , houve paralisação de mais de 1000 atividades, sendo cerca de 240 na área de "intermediários", que correspondem aos produtos que atendem ao setor eletroeletrônico, além de outras atividades, na ordem de 200, que também não foram implantadas. A área de Química Fina é dominada por empresas transnacionais de grande porte, muito embora existam algumas nacionais, de porte médio. A sugestão é que o Brasil construa uma área de química orgânica, (OLIVEIRA, 2005), o que provavelmente seria obtido a partir de empresas de base petroquímica.

Consulta a empresas que formam os pólos petroquímicos mais importantes do país, na Bahia e em São Paulo, mostrou que estas:

- Usam software de controles via de regra dedicados e construídos em parcerias com empresas especializadas;

- Os ciclos de produção, quando formados, são internos ao ambiente de produção.

O resultado é similar ao encontrado anteriormente e descrito nos aspectos teóricos deste trabalho. Assim, a produção de químicos finos, e sua aplicação no setor eletroeletrônico, mostrou ser um ciclo aberto e não foi encontrado um meio eficaz de se utilizar os conceitos de Ecologia Industrial e de formação de ecossistemas industriais para melhorar os aspectos ambientais dessa área. 


\subsection{3. Área de microeletrônica}

A área de microeletrônica vem sendo continuamente estudada nos últimos 20 anos, no que concerne ao impacto ambiental da fabricação de dispositivos semicondutores. De modo geral a área é considerada de baixo impacto em toda a cadeia. Assim, em 1995 (PEDERSEN, 1995), durante a formulação americana do rodmap da área para a década, muito embora tenham sido estabelecidas metas de redução de emissão, ressalvou-se que "a indústria eletrônica, a maior na área de manufatura nos EUA, é há muito considerada relativamente limpa, já que a fabricação de computadores e eletrônicos contribui apenas com $1,6 \%$ do total de resíduos perigosos emitidos no país... as conseqüências ambientais dos processos são mais decorrentes dos materiais utilizados, do consumo de energia e do descarte ao final da vida".

No país, Gameiro (2002) sugeriu processos de minimização da formação de resíduos e determinou as emissões desta área no país, também concluiu que:

- O principal impacto ambiental é a fabricação e o consumo de água deionizada;

○ O impacto pode ser minimizado pela formação de ecossistema industrial entre a área de microeletrônica e galvânicas.

- Observou que o ecossistema industrial efetivamente se formava em pelo menos uma empresa.

- Os outros co-produtos formados são de difícil utilização, pelo pequeno volume.

Uma vez que a água utilizada na empresa tem graus de limpeza e finalidades muito distintas, Gameiro também sugeriu um processo de classificação da água, de acordo com fatores econômicos, ambientais e volume de consumo. A Tabela 3.9 reproduz sua proposta onde se observa que o alto custo de produção e grande volume de água residuária formada durante esta produção prioriza o reuso da água deionizada (di), contudo um grande impacto é das soluções aquosas, para as quais não foram encontradas formas de reuso. 
Após a classificação da água, ciclos internos são montados, da água mais pura para a de menor pureza, o que pode economizar até $66 \%$ da água. A remanescente pode ser, após tratamento, reciclada pelo uso em galvânicas.

Como o estudo de Gameiro possuía cerca de quatro anos, antes de avaliar como aplicar o conceito de Ecologia Industrial à área de microeletrônica utilizando estes dados, procedeu-se a uma verificação junto às empresas se o conjunto de informações recolhidas haviam sofrido variação significativa. A maior variação decorre da desativação de uma das empresas, que na época em que Gameiro as caracterizou correspondiam a três, encontravam-se no estado de S. Paulo e compunham o setor de microeletrônica na época do estudo. As duas empresas remanescentes envidaram esforços para fechar o ciclo de uso de água, sem impacto significativo na quantidade e nos resíduos produzidos.

Tabela 3.9: Caracterização dos tipos de água em relação aos fatores econômico, ambiental e de consumo de acordo com (GAMEIRO 2002)

\begin{tabular}{|c|c|c|c|}
\hline & \multicolumn{3}{|c|}{ FATOR } \\
\hline & ECONÔMICO & AMBIENTAL & CONSUMO \\
\hline $\mathrm{H}_{2} \mathrm{O}$ DI & $\begin{array}{ll}\text { - } & \text { Compra } \\
& \left(\mathrm{H}_{2} \mathrm{O} \text { Comum }\right) \\
\text { - } & \text { Fabricação } \\
\text { - } & \text { Tratamento } \\
\end{array}$ & $\begin{array}{l}\text { Geração De Resíduo De: } \\
\text { - } \quad \text { Processos } \\
\text { - Resinas De Troca Iônica }\end{array}$ & Médio \\
\hline $\begin{array}{c}\text { Grau de } \\
\text { prioridade }\end{array}$ & $1^{\mathrm{o}}$ & $1^{\mathrm{o}}$ & $3^{\circ}$ \\
\hline $\mathrm{H}_{2} \mathrm{O}$ comum & $\begin{array}{ll}\text { - } & \text { Compra } \\
\text { - } & \text { Tratamento }\end{array}$ & - Resíduo De Processos & Muito Alto \\
\hline $\begin{array}{c}\text { Grau de } \\
\text { prioridade }\end{array}$ & $3^{\circ}$ & $2^{\circ}$ & $1^{\mathrm{o}}$ \\
\hline $\mathrm{H}_{2} \mathrm{O}$ residuária & - $\quad$ Tratamento & - $\quad$ Resíduo (Lodo) & Alto \\
\hline $\begin{array}{c}\text { Grau de } \\
\text { prioridade }\end{array}$ & $2^{\mathrm{o}}$ & $3^{\circ}$ & $2^{o}$ \\
\hline Solução aquosa & 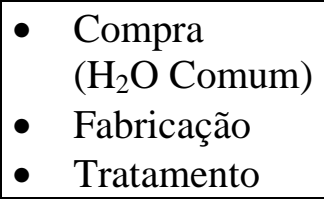 & - Resíduo De Processos & Baixo \\
\hline $\begin{array}{c}\text { Grau de } \\
\text { prioridade }\end{array}$ & $4^{\circ}$ & $4^{\circ}$ & $4^{\circ}$ \\
\hline
\end{tabular}

1 - muito alto, 2 - alto, 3 - médio, 4 - baixo 
Os principais resíduos, que não água, determinados por Gameiro, e aqui denominados co-produtos, bem como suas possíveis utilizações estão listados na Tabela 3.10. Devido à contaminação de metais que ocorre na maioria dos co-produtos, o uso mais provável é na indústria metalúrgica, que além de trabalhar com metais possui pouca necessidade de controle de pureza dos reagentes e/ou soluções.

Adicionalmente aos resíduos sólidos encontrados no lodo galvânico, há abundância de cobre e alumínio, possíveis co-produtos, que podem ser extraídos do processo de usinagem dos encapsulamento prontos para a comercialização.

O lodo corresponde a uma mistura bastante complexa, que Gameiro analisou usando ICP-AES (Ion Coupled Plasma Atomic Emission Spectoscopy). Essa mistura advem do tratamento da água residuária e, portanto, apresenta contaminantes advindos de praticamente todos os processos de produção das respectivas empresas. Foram analisados os seguintes elementos: $\mathrm{Al}, \mathrm{Ca}, \mathrm{Co}, \mathrm{Cu}, \mathrm{Cr}, \mathrm{Cd}, \mathrm{Fe}, \mathrm{K}, \mathrm{Mg}, \mathrm{Mn}, \mathrm{Mo}, \mathrm{Na}, \mathrm{Ni}, \mathrm{P}, \mathrm{Pb}, \mathrm{S}, \mathrm{Sn}$, Zn. De modo geral, para as amostras após secagem observou-se que:

- $\mathrm{Al}, \mathrm{Ca}, \mathrm{Fe}, \mathrm{Na}, \mathrm{P}, \mathrm{S}, \mathrm{Sn}$ encontravam-se na faixa de 1000 a 4000 ppm;

- $\mathrm{Cr}, \mathrm{Cu}, \mathrm{K}, \mathrm{Mg}$, Ni encontravam-se na faixa de 100 a 400 ppm;

- $\mathrm{Co}, \mathrm{Mn}, \mathrm{Mo}, \mathrm{Pb}, \mathrm{Zn}$ encontravam-se na faixa de 10 a 40 ppm;

- Cd encontrava-se em pequena proporção, abaixo de 1 ppm.

Gameiro avaliou que "as altas concentrações de $\mathrm{Ni}, \mathrm{S}$ e $\mathrm{P}$ podem advir dos processos em sala limpa, que utilizam ácidos e base, Ca foi adicionado no tratamento de efluentes, $\mathrm{Na}, \mathrm{Cu}$ e $\mathrm{Sn}$ provavelmente são provenientes dos processos galvânicos ou catalisadores adicionados em banhos, Fe pode vir de tubulações e material de manuseio, $\mathrm{Al}$ é matéria-prima usada nos encapsulamentos e $\mathrm{Mg}$ pode advir de algum reagente, que não é especificado no rótulo, pelo fabricante."

Para a maioria dos co-produtos, como pode ser observado na Tabela 3.10, pode-se propor um uso adequado, sendo restritivo apenas o custo (aspecto econômico) para a troca de co-produtos. Assim, novamente a distância torna-se um fator primordial. Outra característica importante é que tais co-produtos podem ser utilizados por empresa similar, ou até mesmo a própria empresa, da principal correlação entre produção de silício e uso de co-produtos, como visto no item anterior. Por fim, é relevante observar que a maioria, 
se não a totalidade, dos co-produtos podem também ser encontrados na área de circuito impresso, abordado no próximo item.

Deste modo, o indicador mais adequado para o uso destes co-produtos, devido ao baixo volume, é a possibilidade de interação com empresas do setor galvânico. Esta observação é bastante relevante porque corrobora a proposta de uso de água residuária encontrada no trabalho de Gameiro.

Neste trabalho, efetuou-se uma busca por empresas galvânicas e metalúrgicas instaladas no estado de S. Paulo e verificou-se a possibilidade de troca de co-produtos, com o uso de ácidos e bases para a etapa de decapagem. Contudo não se encontrou propostas deste uso nem interessados em implantação, portanto tem-se nesta etapa um campo amplo de pesquisa. De fato os estudos mais recentes ainda sugerem tratamento e descarte de soluções ácidas e básicas, não reciclagem (PASQUALINI, 2004).

Tabela 3.10 principais resíduos, determinados por Gameiro (GAMEIRO, 2002), e neste trabalho denominado por co-produtos, e sugestões de possíveis utilizações

\begin{tabular}{|c|c|c|}
\hline $\begin{array}{l}\text { Principais } \\
\text { Coprodutos }\end{array}$ & Informações Relevantes & Possíveis Utilizações \\
\hline \multicolumn{3}{|c|}{ Gasosos } \\
\hline $\begin{array}{l}\text { Vapores ácidos e } \\
\text { básicos }\end{array}$ & $\begin{array}{l}\text { Advindos de processos de produção: } \\
\text { Encontrado nos exaustores; } \\
\text { Removidos por lavagem com água* }\end{array}$ & ---- \\
\hline \multicolumn{3}{|c|}{ Líquidos } \\
\hline $\begin{array}{c}\text { Ácidos: } \mathrm{HNO}_{3} \\
\mathrm{H}_{3} \mathrm{PO}_{4}, \mathrm{H}_{3} \mathrm{BO}_{3}, \mathrm{HCl} \\
\mathrm{H}_{2} \mathrm{SO}_{4}\end{array}$ & $\begin{array}{l}\text { Produção de cerca de centena de } \\
\text { litros/mês para cada reagente; } \\
\text { Contaminação de metais } \\
\text { (provavelmente da ordem de dezenas de } \\
\text { ppm) }\end{array}$ & $\begin{array}{l}\text { Uso no processo inicial de } \\
\text { “decapagem" em empresa } \\
\text { metalúrgica }\end{array}$ \\
\hline Bases: $\mathrm{NH}_{4} \mathrm{OH}$ & Semelhante aos ácidos & $\begin{array}{l}\text { Uso no processo inicial de } \\
\text { "decapagem" em empresa } \\
\text { metalúrgica }\end{array}$ \\
\hline $\begin{array}{l}\text { Soluções aquosas de } \\
\text { sais de Ni e Al }\end{array}$ & $\begin{array}{l}\text { Produção de cerca de centena de } \\
\text { litros/mês para cada reagente; } \\
\text { Contaminação provável: }\end{array}$ & $\begin{array}{c}\text { Recuperação do metal em } \\
\text { empresa especializada }\end{array}$ \\
\hline $\begin{array}{l}\text { Solução aquosa de } \\
\text { detergentes: } \\
\text { catiônicos e } \\
\text { aniônicos }\end{array}$ & $\begin{array}{l}\text { Produção de cerca de centena de } \\
\text { litros/mês para cada reagente; } \\
\text { Contaminação provável: resíduos de } \\
\text { gordura }\end{array}$ & $\begin{array}{l}\text { Uso no processo inicial de } \\
\text { "limpeza" em empresa } \\
\text { metalúrgica }\end{array}$ \\
\hline $\begin{array}{l}\text { Solventes orgânicos, } \\
\text { principalmente } \\
\text { álcool isopropilico }\end{array}$ & $\begin{array}{l}\text { Produção de cerca de centena de } \\
\text { litros/mês para cada reagente; } \\
\text { Contaminação provável: resíduos de } \\
\text { outros solventes e água, na faixa menor } \\
\text { que porcentagem }\end{array}$ & $\begin{array}{l}\text { Uso no processo inicial de } \\
\text { "limpeza" em empresa } \\
\text { metalúrgica }\end{array}$ \\
\hline
\end{tabular}




\begin{tabular}{|c|l|l|}
\hline \multicolumn{3}{|c|}{ Sólidos } \\
\hline Lodo galvânico, & $\begin{array}{l}\text { Produção de centenas de litro/mês ("fase } \\
\text { semi-sólida") } \\
\text { Composto por sais de cálcio ou bário } \\
\text { (usados na formação do lodo) e como } \\
\text { contaminante principalmente cobre } \\
\text { alumínio e silício. A composição do } \\
\text { lodo será abordada posteriormente. }\end{array}$ & $\begin{array}{l}\text { Uso para fabricação de } \\
\text { cerâmica; } \\
\text { Recuperação do metal em } \\
\text { empresa especializada }\end{array}$ \\
\hline Sucata metálica & $\begin{array}{l}\text { Pó, principalmente de cobre e alumínio, } \\
\text { advindos da usinagem de } \\
\text { encapsulamentos de } \\
\text { Quantidade da ordem de poucos quilos } \\
\text { mensais }\end{array}$ & Uso em empresa metalúrgica \\
\hline $\begin{array}{l}\text { Refugo de } \\
\text { produção: silício }\end{array}$ & $\begin{array}{l}\text { Advindo de erros de produção e } \\
\text { quebra }\end{array}$ & $\begin{array}{l}\text { Formação de ligas, em } \\
\text { empresa metalúrgica }\end{array}$ \\
\hline $\begin{array}{l}\text { Refugo de } \\
\text { produção: } \\
\text { componentes } \\
\text { encapsulados }\end{array}$ & Produção inferior a quilograma/mês & \\
\hline
\end{tabular}

* - sugestão de minimização de formação de resíduos; os valores de produção mensal consideram apenas duas empresas

\subsubsection{Conclusão Parcial}

O primeiro estudo de caso caracterizou o setor de base da indústria de equipamentos eletrônicos, o da microeletrônica. Com base em referências puderam-se verificar quais eram as etapas do processo que geravam mais quantidade de possíveis coprodutos, identificá-los e quantificá-los. Isso possibilitou uma avaliação mercadologia, via software, dos valores econômicos de cada co-produto e de sua utilização em outros setores e/ou etapas da cadeia de produção.

O resultado da avaliação no sistema SAP, de possíveis clientes e fornecedores, conclui que o cobre e o alumínio são os principais co-produtos a serem comercializados. A pesquisa também mostra que a água é melhor aproveitada em ecossistemas internos, já que seu transporte é crítico, considerando-se o baixo valor agregado em relação ao custo do transporte. Já o cobre e o alumínio têm um valor maior e um alto consumo em diversas indústrias, contudo sua circulação é rentável somente em grandes quantidades, 
de outra forma o reaproveitamento interno é mais lucrativo, e corresponde a uma alternativa tecnológica não avaliada.

Para que quantidades que viabilizem o transporte e a comercialização sejam acumuladas, é imprescindível a formação de cooperativas e/ou banco de resíduos, entre as empresas de microeletrônica. Para isto a troca de informação de forma ágil é essencial, neste ponto um sistema integrado de gestão de co-produtos seria eficaz, por gerar relatórios de consumo de descarte de componentes, assim como previsão de produção e demanda.

\subsubsection{A Área De Circuito Impresso E Montagem Em Superfície}

As áreas de produção de placas de circuito impresso (PCIs) e de montagem em superfície (SMT, surface mounting technology) apresentam similaridades e, no país, muitos stakeholders, tais como associações, representam os dois simultaneamente.

Vários estudos propuseram a minimização de resíduos nas duas áreas, principalmente na década de 80 e 90 . Via de regra estes estudos verificaram que havia ganho, ecológico e econômico, com propostas de minimização, como a avaliação de três empresas de PCIs e uma de SMT demonstrou na Áustria (SAGE, 19995). No final da década de 80 a área de circuito impresso foi definida como uma das mais propícias para a diminuição do uso de solventes halogenados, junto com a área de semicondutores (JACOBS, 1988).

Hui (2003) propôs para a área um sistema de avaliação que permite computar o impacto de produto usando uma metodologia muito semelhante à de avaliação do ciclo de vida. Os principais produtos encontrados em respeito ao impacto ambiental foram principalmente solventes orgânicos e soluções aquosas com sais metálicos. Também concluiu que o impacto é maior na área ambiental do que na saúde humana. Resposta semelhante conseguiu a indústria britânica, em seu guia técnico para a área. Como (GRENN, 2000) argumenta reportagem recente, a área de PCI "utiliza quantidade considerável de metais pesados, compostos orgânicos voláteis e, por isso, o gasto com controle ambiental nas empresas da área corresponde a $6 \%$ do valor total do produto, bem maior do que a média da indústria britânica, que é de $2 \%$... Além disso, a indústria tem 
elevado consumo de água e o relatório sugere que há a possibilidade de redução de consumo de água em 50\%". Resultado não muito distinto também foi encontrado para Singapura (PENG, 2005). Na Turquia, Yilmaz (2006) determinou os principais resíduos obtidos nos mais importantes setores de produção. Para a área de circuito impresso, os resíduos e quantidades produzidas são mostrados na Tabela 3.11, para o ano de 2006. Para o Greenpeace Research Laboratories, unidade do Greenpeace International, três áreas do setor eletroeletrônico são críticas: semicondutores, PCIs e telas LCD (WALTERS, 2006). Quanto aos resíduos preocupantes, são apontados metais, surfactantes e compostos orgânicos, principalmente.

Tabela 3.11. Principais resíduos e quantidades produzidas pela área de circuito impresso na Turquia

\begin{tabular}{|c|c|}
\hline Resíduo & $\begin{array}{c}\text { Quantidade produzida } \\
\text { (tonelada/ano) }\end{array}$ \\
\hline Lodo contendo substâncias potencialmente perigosas & 225 \\
\hline Lodo de tratamento de água de entrada da planta & 90 \\
\hline Soluções ácidas & 270 \\
\hline Soluções alcalinas & 225 \\
\hline Metais preciosos (Ag, $\mathrm{Au}, \mathrm{Cu}, \mathrm{Ni}, \mathrm{Pd}, \mathrm{Sn}, \mathrm{Pb})$ & 0,01 \\
\hline
\end{tabular}

No país, Silva (1998) determinou os principais resíduos da fabricação de PCIs, dentro do programa QITS, anteriormente descrito. Além do exacerbado consumo de água outro impacto significativo era o descarte de soluções aquosas ácidas e alcalinas.

A área de SMT foi descrita por Gameiro (2005) como crítica para o descarte de pasta de solda, formada principalmente por liga metálica de estanho/chumbo e produtos orgânicos, genericamente denominado fluxo. Esta pasta é descartada em grande volume devido a pouca durabilidade desta e características do processo de fabricação. Assim, nesta área o resíduo sólido é responsável também por alto impacto econômico, devido ao custo do descarte.

\subsubsection{Caracterização Da Área}

Como o estudo do início da cadeia mostrou a existência de co-produtos muito semelhantes aos encontrados na área de circuito impresso, mas esta havia sido avaliada há longo tempo, procedeu-se a uma reavaliação. O procedimento foi desenvolvido e 
implantado em parceria com a ABRACI (Associação Brasileira de Circuito Impresso). A ABRACI representa não só os fabricantes de circuito impresso mas também seus fornecedores além de ter contatos com representantes da área de SMT.

No país cerca de 40 empresas produzem circuitos impressos e sua distribuição não é homogênea, havendo maior concentração de empresas em Amazonas, S. Paulo e Paraná. Situação semelhante ocorre para a área de SMT. Essas empresas têm pequeno número de funcionários, o que pode caracterizá-las como pequenas e médias, mas, muitas vezes, por se tratar de produtos de alto valor agregado, apresentam faturamento maior do que o comum para a média e pequena empresa. $\mathrm{O}$ procedimento estabelecido para a caracterização da área foi como segue:

1. criação de um questionário, junto com os representantes do conselho ambiental da entidade, a ser enviado a todos da área de circuito impresso e correlatos, tais como fornecedores. O questionário encontra-se no Anexo 8;

- o objetivo do questionário é verificar todos os co-produtos e/ou resíduos formados pela empresa, sua quantificação e destinação.

2. envio do questionário;

3. tabulação dos resultados de modo que:

- possíveis co-produtos sejam determinados e quantificados,

- propostas de destinação idêntica sejam encontradas,

- propostas de destinação distintas sejam identificadas,

4. análise dos resultados de acordo com as ferramentas da ecologia industrial

- identificação de possíveis usos, formação de ecossistemas industriais, etc.

5. divulgação dos resultados para todos os envolvidos no processo (associados).

Obteve-se $20 \%$ de resposta dos questionários enviados. As empresas que responderam correspondem, via de regra, às de maior porte, e que, portanto, atendem a maioria do mercado, e além disso, a maioria também se encontra em São Paulo. Tem-se ainda que $80 \%$ das empresas apresentam licença ambiental para o descarte, contudo apenas $15 \%$ possuem certificação ISO. Além disso, cerca de $80 \%$ das empresas destinam o lodo a apenas um reciclador. Os resultados obtidos encontram-se tabulados na Tabelas 3.12 . 
Tabela 3.12 Principais resíduos de acordo com 20\% dos associados da ABRACI

\begin{tabular}{|c|c|c|c|}
\hline Material & $\begin{array}{c}\text { Empresas que } \\
\text { destinam (\%) }\end{array}$ & $\begin{array}{c}\text { Empresas que } \\
\text { pagam para o } \\
\text { descarte(\%) }\end{array}$ & $\begin{array}{c}\text { Empresas que descartam sem } \\
\text { custo direto (via associaçóes, } \\
\text { ou prefeitura) (\%) }\end{array}$ \\
\hline $\begin{array}{c}\text { Metais Ferrosos e não } \\
\text { Ferrosos }\end{array}$ & 20 & 46 & 34 \\
\hline $\begin{array}{c}\text { Sucata de Metais Não } \\
\text { Ferrosos }\end{array}$ & 53 & 13 & 34 \\
\hline $\begin{array}{c}\text { Papel, Papelão, } \\
\text { Plástico, Madeira }\end{array}$ & 26 & 33 & 41 \\
\hline Lixo de Restaurante & 0 & 50 & 50 \\
\hline Fenol & 0 & 100 & 0 \\
\hline Varrição de Fábrica & 0 & 54 & 46 \\
\hline $\begin{array}{c}\text { Torta de Filtro Prensa } \\
\text { Lodo Galvânico da ETE }\end{array}$ & 0 & 94 & 40 \\
\hline $\begin{array}{c}\text { Embalagens } \\
\text { contaminadas }\end{array}$ & 33 & 13 & 0 \\
\hline $\begin{array}{c}\text { Solvente com cobre } \\
\text { Solvente sem cobre }\end{array}$ & 60 & 0 & 0 \\
\hline $\begin{array}{c}\text { Efluentes ácidos ou } \\
\text { alcalinos }\end{array}$ & 50 & 94 & 0 \\
\hline $\begin{array}{c}\text { Laminado de "epox } \\
\text { cobreado" }\end{array}$ & uma única empresa, dependendo da quantidade, vende por 0,07 \\
/kg ou paga o descarte a 0,13 /kg.
\end{tabular}

Via de regra observa-se que os co-produtos gerados são aqueles mais comuns da área: metais, soluções aquosas e lodo galvânico, principalmente. De modo geral a destinação para reciclagem é apenas para soluções que apresentem alta concentração de metais. Assim, a maioria dos possíveis co-produtos recebe uma destinação ambientalmente correta, mas não economicamente, pois poderiam ser parte de um ecossistema industrial. Portanto, definiu-se como necessário avaliar a formação de tal sistema nessa área.

Dada à importância do lodo galvânico, uma vez que este é semelhante em composição e no modo de produção ao da área de semicondutores em particular e das indústrias galvânicas no geral, procedeu-se posteriormente a investigação mais crítica sobre a destinação deste lodo. Para tanto foram consultados pessoalmente, via entrevista, os maiores produtores. Constatou-se, então, que muitas vezes o lodo é enviado para empresa especializada para remoção de metais. O envio tem custo de envio para o exterior e é considerado como destinação de resíduo, o que exige documentação pertinente, o que também implica em alto custo e demanda mais tempo. Assim, para este 
co-produto existe um ecossistema, mas ele é aberto. $\mathrm{O}$ ecossistema não define o coproduto como tal, o que é economicamente desfavorável.

Procedimento e situação semelhante ocorrem para o descarte de refugos de produção, que apenas pelo preenchimento do questionário não permitia discernir qual era a destinação mais freqüente. Normalmente denominados de sucata eletrônica, correspondem a produtos semi-acabados que se mostraram ineficientes e sem possibilidade de retrabalho. Nesse caso é comum o envio para tratamento como sucata, o que muitas vezes também ocorre fora do país.

Por fim, alguns produtos não diretamente ligados ao processo produtivo, como embalagens, são destinados a recicladoras.

\subsubsection{Avaliação Da Área Com O Uso De Software}

Dentre os possíveis co-produtos listados no questionário, escolheram-se aqueles com maior probabilidade de reuso. Como critério considerou-se o aspecto econômico (maior valor de revenda) e ambiental (maior impacto). O aspecto social, uma vez que os estudos de caso mundialmente apontam para pouco impacto na saúde do trabalhador e/ou comunidade, fica, portanto, apenas implícito. Segundo o questionário, os co-produtos com maior valor de revenda e seu valor médio, obtido pelas empresas da área, encontram-se na Tabela 3.13. Como demonstra a Tabela 3.13, por este critério a maioria dos resíduos da indústria de circuito impresso é considerada como co-produto, as exceções são as soluções aquosas e/ou reagentes e lodo de tratamento de efluentes.

Tabela 3.13 estimativa do valor médio econômico dos co-produtos gerados por fabricantes de circuitos impressos

\begin{tabular}{|l|l|}
\hline \multicolumn{1}{|c|}{ Co-produto } & \multicolumn{1}{c|}{ Valor } \\
\hline Cobre/Alumínio & $\mathrm{R} \$ 1,00 / \mathrm{kg}$ \\
\hline Papel & $\mathrm{R} \$ 0,15 / \mathrm{kg}$ \\
\hline Termoplásticos & $\mathrm{R} \$ 0,15 / \mathrm{kg}$ \\
\hline Outros Metais & $\mathrm{R} \$ 0,35 / \mathrm{kg}$ \\
\hline Efluentes com cobre & $\mathrm{R} \$ 0,15 / \mathrm{L}$ \\
\hline
\end{tabular}

Os dados obtidos com o questionário foram inseridos no software SAP R/3, com a finalidade da determinação do melhor processo e caminho ótimo para circulação de co- 
produtos entre empresas, para formação de ecossistemas industriais. Os dados inseridos foram comparados com os dados de empresas recicladoras - ou empresas consumidoras do co-produto em questão - que se encontram no estado de S. Paulo e que também usam este software. A restrição imposta à distância deve-se ao aspecto econômico, pelo alto custo do transporte, e ao aspecto ambiental, pela emissão de $\mathrm{CO}_{2}$. Observe-se que o questionário revelou que todos os co-produtos da área são vendidos exclusivamente para empresas recicladoras, ocorrendo, portanto, dois passos na cadeia: um de processamento e outro de revenda. Contudo, esta restrição não foi imposta a esta simulação de compra e venda via software, podendo ocorrer venda direta entre empresas. A simulação em questão usou listagem de empresa de consultoria especializada neste software. Esta lista inclui, deve-se notar, a maioria das empresas do estado que utilizam tal software.

Com a relação de oferta e demanda inserida no software e estimou-se o valor econômico e/ou e a possível remuneração dos co-produtos listados na Tabela 3.13. A simulação do ecossistema via o software foi feita como descrito pelo gráfico de Ishikawa da Figura 3.11. Esta simulação, como comentado anteriormente, assemelha-se à avaliação do ciclo de vida.

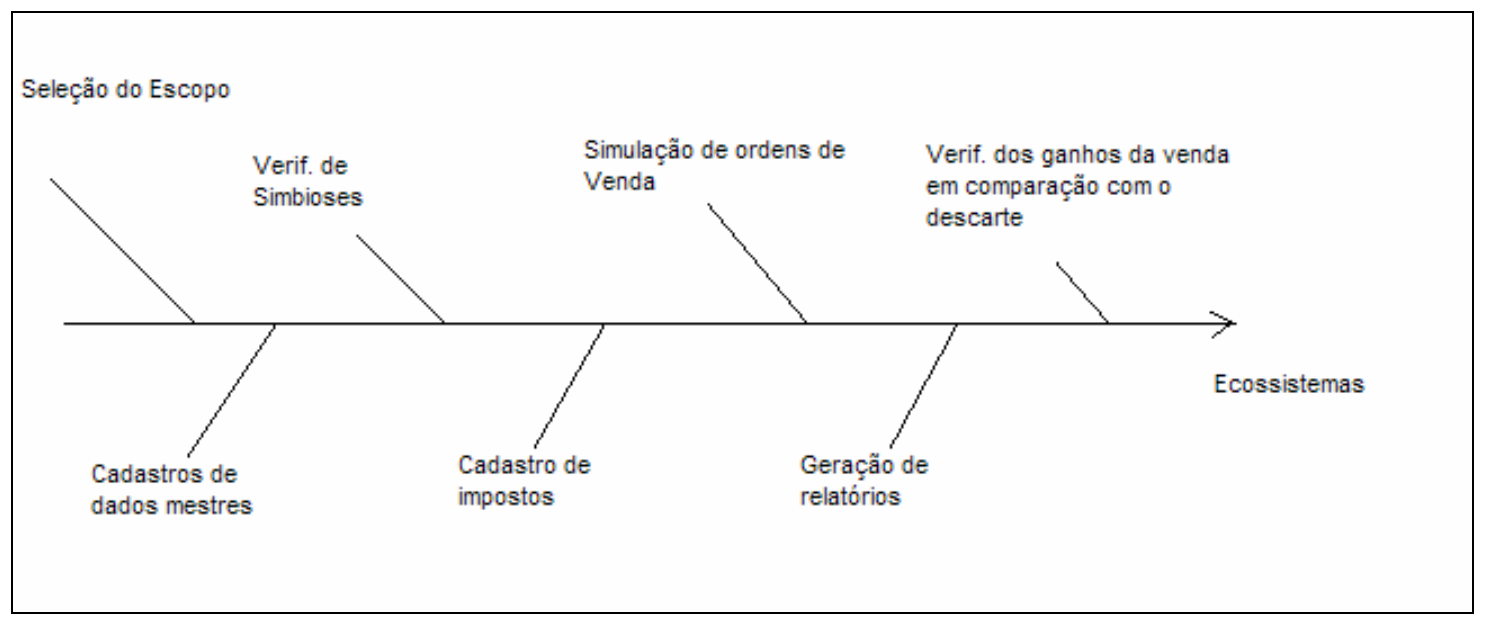

Figura 3.11 cadastro no SAP das empresas de circuitos impressos e o caminho da simulação do ecossistema via o software, descrito em um gráfico de Ishikawa

Como mostra o gráfico da Figura 3.11 as etapas da simulação do ecossistema são:

A seleção do escopo: Empresas de Placas de Circuito Impresso, Químicas, Indústrias de Componentes e Indústrias de equipamentos eletrônicos. As funcionalidades 
selecionadas do software formam os dados mestres com informações de fornecedores, clientes e materiais.

O Cadastro dos dados mestres no sistema: todas as empresas e materiais envolvidos foram cadastrados.

Verificação de Simbioses: Define-se, via software, a necessidade de comparar dados de entrada e saída (compra e venda, respectivamente) das empresas.

Cadastro de impostos: Cadastro de toda a carga tributária envolvida na comercialização do co-produto considerando os locais de entrega. Com isso pode-se comparar o custo do descarte de resíduos com o da venda de co-produtos.

Simulação das Ordens de Venda: De acordo com o sistema de MRP e previsão de demanda pode-se simular ordens de venda para verificação do ganho na venda de coprodutos, considerando a carga tributária e o custo do frete, dependendo da localização do cliente e do depósito fornecedor.

Geração de Relatórios: Todos os dados resultantes alimentaram indicadores propostos pela Ecologia Industrial, com a finalidade de apresentá-los através de um Balance Scorecard.

Verificação dos Ganhos em comparação com o descarte: O custo do descarte pode ser comparado com o lucro da venda.

Um relatório final com os resultados, na forma do Balance Scorecard encontrado no Anexo 5, é enviado para a ABRACI para análise do conselho ambiental.

$\mathrm{O}$ estudo dos co-produtos, como descritos anteriormente, mostrou para possibilidade de ganho econômico para toda a lista da Tabela 3.13. Contudo, devido ao alto valor econômico e volume de produção, entre os possíveis co-produtos, o ganho mais expressivo corresponde ao cobre. A simulação demonstrou que empresas fornecedoras da área de PCIs adquirem cobre de empresas pertencentes ao final da cadeia de produção. $\mathrm{O}$ cobre em questão encontra-se em forma e com características semelhantes ao descartado na área de circuito impresso. Supondo-se a venda direta do cobre para as empresas fabricantes de insumos para as placas de circuito impresso, obtém-se um aumento no valor venal de $270 \%$ na média e de $400 \%$ máximo, mesmo considerando-se o pagamento de todos os encargos. O limitante é a exigência dos clientes da entrega da matéria-prima 
no momento preciso e na quantidade necessária (just in time). O sistema de entrega sob encomenda não é de difícil de implementação, pois a área de estoque necessária será pequena, devido à alta densidade do material. Portanto, o sistema é economicamente viável além de ambientalmente favorável, já que as distâncias a serem percorridas são pequenas.

Para outros co-produtos, listados na Tabela 3.13, de baixo valor econômico e baixa toxicidade, economicamente não se encontrou solução mais adequada e ambientalmente a avaliação deve levar em conta a emissão de gás carbônico no transporte, cuja valoração de impacto, como abordada anteriormente, é alta. Assim, para papel e termoplásticos o envio para recicladoras continua sendo adequado.

Não se encontrou uma solução adequada, usando o mesmo procedimento, para o uso de soluções aquosas e/ou reagentes e do lodo de tratamento de efluentes. As soluções e reagentes são úteis em metalúrgicas, que se encontram distantes e não apresentaram interesse no reuso dos produtos, e o segundo precisa de desenvolvimento de procedimento específico para reciclagem.

Quanto à reciclagem do lodo, como a maioria das soluções é ácida e o lodo é obtido por precipitação em $\mathrm{pH}$ alto, é possível que um procedimento de dissolução e recuperação de metais seja desenvolvido utilizando estes dois resíduos como co-produtos. Assim, há uma ampla área de pesquisa a ser abordada quanto a este aspecto. No momento, lodo com tais características recebe descarte em aterro industrial ou inertização por tocha de plasma na indústria de galvanoplastia, mas há estudo de caso sugerindo o uso de areia de fundição para a formação de produto inerte, o que pode ser um ecossistema incipiente. (BORGO, 2005)

Quanto à área de SMT, a recuperação de chumbo e estanho (cerca de $60 \%$ em peso da pasta de solda) implica numa situação similar à encontrada para o cobre na área de circuito impresso, contudo não se encontrou, na simulação processada, empresa que utiliza tal insumo. Assim, há uma oportunidade de negócios e melhoria ambiental a ser avaliada nesta área.

O segundo maior descarte da área, produtos semi-acabados, apresentam características semelhantes ao descarte de produtos acabados e será avaliado posteriormente. 


\subsubsection{Conclusão Parcial}

Para a área de circuito impresso observou-se, com o uso do conceito de Ecologia Industrial, que a formação de alguns ecossistemas industriais apresenta vantagens econômicas e ambientais.

Tanto para a área de circuito impresso como SMT há algumas oportunidades de desenvolvimento de tecnologia e oportunidades de negócios. Contudo, esta questão foge ao escopo deste trabalho.

\subsubsection{Montagem E Descarte De Equipamentos}

A desmontagem de equipamentos recebeu muita atenção nas últimas décadas por vários motivos:

- O grande aumento da produção de equipamentos eletrônicos e o impacto tecnológico e econômico que criou (ZUFFO, 2003);

- A existência de componentes com alto valor de mercado;

- A existência de substâncias raras e/ou caras em sua composição;

- As restrições criadas por órgãos governamentais, devido à possibilidade de contaminação, especialmente do solo, por substâncias tóxicas.

Diversos modelos foram criados para descrever os processos envolvidos no descarte de equipamentos eletrônicos após sua utilização. Contudo, dada a complexidade da área todos estes modelos apresentam limitações. Assim, enquanto a reciclagem de um eletrodoméstico via de regra cria como principal co-produto aço inoxidável a reciclagem de equipamentos eletrônicos de uso pessoal, como celulares, é dificultada pelo pequeno 
tamanho do produto, que exige alta integração de componentes. Assim, enquanto alguns produtos são comprados para outros a remoção no ponto de uso requer pagamento.

Dentre os modelos existentes, a proposta de Sodhi (2001) é bastante abrangente para adequar tais particularidades e também permite adaptação a softwares de controle, como o SAP R/3.

Genericamente, Sodhi propõe um caminho de formação de sucata eletrônica como o encontrado na Figura 3.12. Equipamentos de várias fontes distintas são descartados, parte é destinada a aterro e parte é entregue a recicladoras. Após seleção de componentes que devem ser removidos, de placas com alta concentração de cobre, etc., parte do produto volta à cadeia, na forma de componente, parte segue para as metalúrgicas (fundições), para recuperação de substâncias presentes na sucata e parte é destinada a aterro.

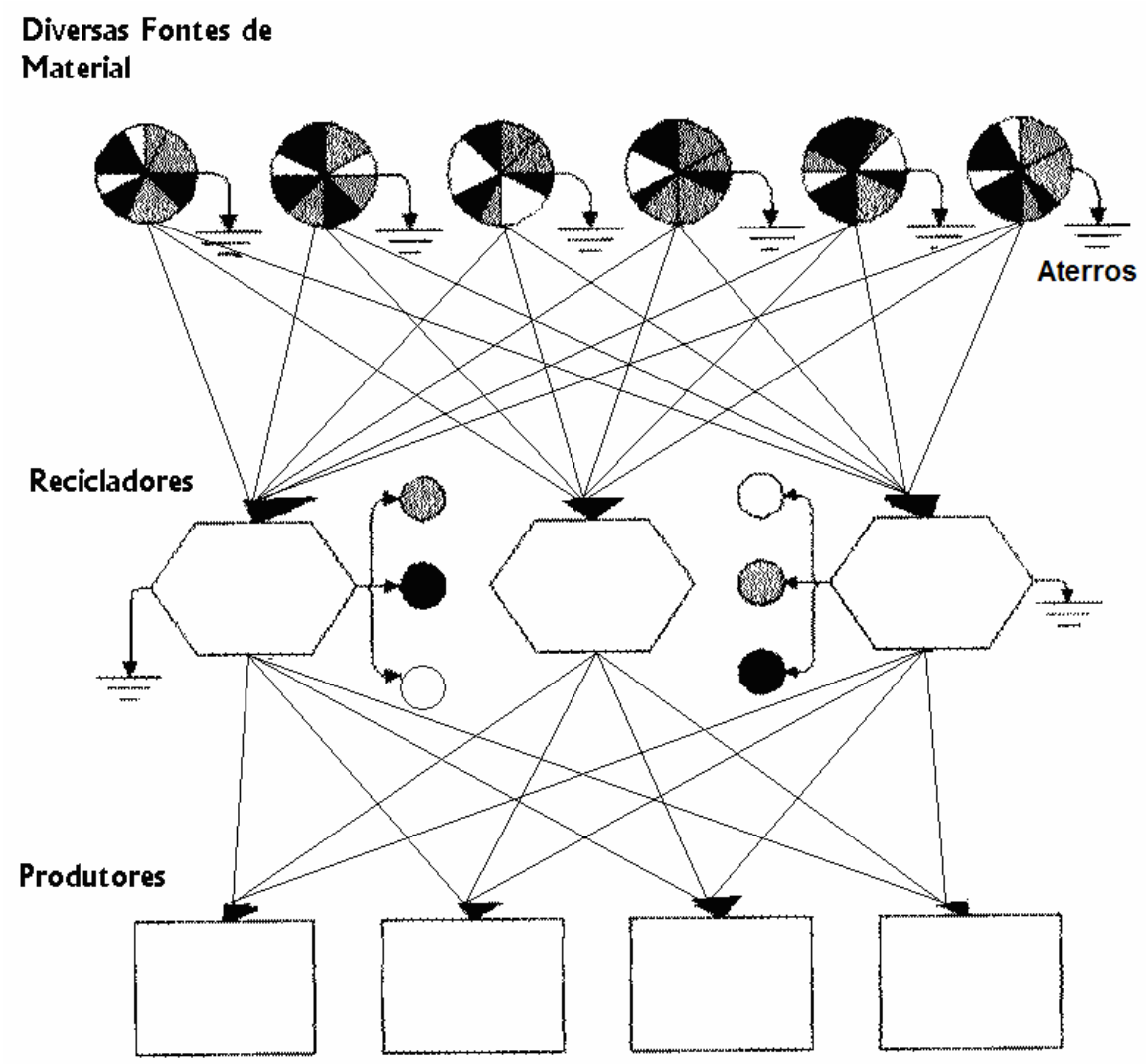

Figura 3.12. caminho de formação de sucata eletrônica, segundo Sodhi (2001) 
Segundo Sodhi (2001), para a fonte geradora de sucata, o importante é minimizar - e se possível lucrar - com o descarte. Os principais fatores que influem no sistema são: custo de transporte do reciclador e custo (ou lucro) de reciclagem do objeto. Assim, minimizar distâncias torna-se fundamental. Além disso, deve-se considerar a composição média do equipamento e o custo de disposição em aterro, para aqueles objetos que não implicam em grande impacto ambiental.

Para os recicladores, há vários processos ocorrendo simultaneamente e com caminhos - e conteúdo tecnológico - bem distintos. Assim, os principais fatores que influem no sistema são: custo de reciclagem do item e lucro após esta, custo de transporte até as metalúrgicas, quantidade de metal presente no item reciclado e possibilidade de mistura de itens distintos para obter a mínima quantidade necessária de metal para compensar o custo de envio do item. Esta parte da cadeia tem muitas decisões importantes o que torna a escolha difícil. Uma etapa que deve ser considerada em separado nesta fase é a desmontagem do produto. A desmontagem pode ser inserida dentro das variáveis listadas anteriormente apenas considerando que cada parte a ser desmontada é um módulo e este precisa ser estudado isoladamente.

Para as metalúrgicas os fatores mais relevantes são: lucro e custo de processamento, quantidade de metal presente no item e eficiência da recuperação.

Este modelo é bastante amplo, porém não considera aspectos ambientais além das exigências legais, portanto não valora questões como imagem da empresa, nem aspectos sociais, como geração de emprego.

O software SAP R/3 pode ser customizado para atender tal modelo e as variáveis requisitadas podem ser obtidas com os dados mestres do programa.

No país, segundo Silva (2004), tanto na eletrônica como na automobilística, “a reciclagem de partes e peças inicialmente tratou-se de uma decisão gerencial visando lucro e hoje ocorre na maioria países desenvolvidos, sem qualquer intervenção governamental, mostrando-se economicamente favorável e, aliada a desmaterialização, tornou o setor bastante desenvolvido... Atualmente os equipamentos eletrônicos tendem a ser modulares, o que inclusive favorece a desmontagem e up grade, o que vai de encontro com o desejado pela Ecologia Industrial. Assim, as placas recebem os componentes eletrônicos e são internalizadas em equipamentos. A partir daqui há um grande interesse 
na desmontagem das placas sucateadas ou dos equipamentos em todo o mundo. No país há empresas recolhendo esse material e levando para reciclagem na matriz, mas aparentemente uma empresa se estabelecerá no país. Um exemplo digno de nota é a Xerox. Ao mudar o enfoque para a venda de serviço em lugar de equipamento pôde reciclar quase todo material que fabrica. Outro nicho de mercado muito importante são os computadores. A ITAU recicla os computadores que foram adquiridos no processo de leasing. Portanto, para grandes volumes a reutilização é muito simples e novamente pode ser feita no processo de parceria. Cartucho de impressão é outro estudo de caso bem conhecido, onde o reciclador não precisa ser o produtor...", quanto à matéria-prima exemplo clássico é a obtenção de metais a partir de resíduos de eletroeletrônicos existentes nas grandes cidades. "De fato, uma empresa nacional também se propôs a atuar na área". A separação dos componentes de um equipamento é primordial para a reciclagem ambientalmente mais correta dos materiais (GAMEIRO, 2003).

O desmonte de equipamentos após seu uso como responsabilidade dos produtores é comum, além dos computadores da ITAU, para impressoras (MINETTI, 2005)

Para partes e peças, além dos cartuchos de tintas o retorno de baterias é comum, devido à determinação legal e/ou decisão empresarial. As grandes baterias ${ }^{3}$ são desmontadas e a maioria de seus componentes reciclados pelos fornecedores, mas as pequenas, como de celulares, são enviadas para reciclagem no exterior.

Devido à importância da desmontagem para a reciclagem de produtos acabados e ao fato da área de SMT gerar como co-produto muitos componentes com defeito, este item foi dividido em duas partes, que apresentam estudos de caso distintos. O primeiro estudo de caso - a reciclagem de um rádio relógio - atende a questão de reciclagem de equipamentos completos. O segundo estudo de caso, reciclagem de computadores e celulares, simula melhor a sucata da área de SMT.

\subsubsection{Reciclagem De Um Rádio Relógio}

Para avaliar se as correlações propostas no item anterior estão corretas, simulouse como pode ocorrer a reciclagem de um equipamento descartado, com formação de

\footnotetext{
${ }^{3}$ Informação obtida junto ao comitê de baterias da ABINEE.
} 
ecossistemas industriais, como previsto pelo modelo de Sodhi (2001). Para tanto se utilizaram informações de equipamentos reais. Os dados necessários à simulação foram obtidos junto à empresa especializada em consultoria no software SAP e correspondem a condições reais encontradas nos equipamentos atuais. $\mathrm{Na}$ área de produção de equipamentos a totalidade das empresas utiliza software de controle e a grande maioria (muito acima de 50\%) o SAP R/3. Em princípio, um equipamento descartado após uso pode ser readquirido pela empresa que o fabricou porque no banco de dados do software consta a localização do equipamento vendido. Procurou-se definir como equipamento a ser reciclado aquele que, como sugere a avaliação prévia da área descrita no item anterior, apresentasse:

- Simplicidade de construção e que a composição média refletisse aproximadamente a composição da sucata eletrônica mais comum;

- Modularidade e concepção simples - facilitando o teste do ecossistema proposto;

- Facilidade de acesso e custo - garantindo provável vida longa do produto;

- Grande volume de produção - caracterizando-o como produtor primário.

$\mathrm{O}$ rádio relógio $\mathrm{AM} / \mathrm{FM}$ atende totalmente estes critérios. Dentro da produção do rádio deu-se prioridade aos metais porque, como verificado no item anterior, dentre as simbioses possíveis, corresponde a uma das mais utilizadas mundialmente (TSAN SU, 1996) e (BHUIE, 2004). Por fim, como o estudo das outras áreas já evidenciou e como propõe o modelo de Sodhi (2001), a distância entre produtor-reciclador-consumidor (metalúrgica) é parâmetro de fundamental importância. Deste modo supôs-se que tanto o descarte como a reciclagem ocorreria no estado de S. Paulo, grande centro consumidor de equipamentos eletrônicos.

A obtenção de dados seguiu uma metodologia semelhante à utilizada na análise de ciclo de vida e obtenção do inventário de produtos/materiais (LCI). Como abordado na introdução deste trabalho, sistemas de ERP têm estas informações dentro das listas técnicas de materiais e pedidos de compra e venda. Os dados foram sumariados e enviados para uma interface (BW), gerando os relatórios (BSC), na forma de uma planilha Excel, onde o material sob análise pode ser selecionado por fornecedor ou tipo 
(Figura 3.13). Para este estudo os componentes foram listados até as matérias-primas. A lista técnica foi rastreada até a obtenção dos insumos da produção, como água e energia elétrica, além de todos os componentes.

Durante a montagem do ecossistema algumas simbioses foram claramente observadas, e estão listadas na Tabela 3.14. As simbioses são determinadas comparando as exigências das listas técnicas nas referidas indústrias (produtor e provável reciclador, etc.).

Tabela 3.14 Possíveis Simbioses Observadas Através Do Uso De Software.

\begin{tabular}{|c|c|c|c|c|}
\hline \multirow{2}{*}{$\begin{array}{c}\text { Produtor } \\
\text { Primário*/Produto }\end{array}$} & \multicolumn{4}{|c|}{ Consumidor } \\
\hline & $\begin{array}{c}\text { Indústria de } \\
\text { eletroeletrônicos }\end{array}$ & $\begin{array}{l}\text { Indústria de } \\
\text { Componentes }\end{array}$ & $\begin{array}{l}\text { Indústria } \\
\text { Química }\end{array}$ & $\begin{array}{l}\text { Indústria } \\
\text { Mineradora }\end{array}$ \\
\hline IR/PCI. & $\mathrm{X}$ & $X$ & & $\mathrm{X}$ \\
\hline $\begin{array}{c}\text { IR/componentes } \\
\text { eletrônicos }\end{array}$ & & $\mathrm{X}$ & & $\mathrm{X}$ \\
\hline $\mathrm{IR} /$ resistor & & $\mathrm{X}$ & & $\mathrm{X}$ \\
\hline IR/cerâmica & & & & $\mathrm{X}$ \\
\hline IR/Alumínio & $\mathrm{X}$ & $\mathrm{X}$ & & $X$ \\
\hline IR/cobre & $\mathrm{X}$ & $\mathrm{X}$ & $\mathrm{X}$ & $\mathrm{X}$ \\
\hline UR/equipamento & & $\mathrm{X}$ & & $\mathrm{X}$ \\
\hline
\end{tabular}

* IR - Produtora do bem ; UR - Usuário do bem de consumo (rádio). PCI - Placa de circuito impresso

\begin{tabular}{|c|l|l|l|c|}
\hline $\begin{array}{c}\text { Grupo De } \\
\text { Mercadorias }\end{array}$ & Material & & Fornecedor \\
\hline 03 & Informática & 000000000000023714 & SERVIDOR INTEL & 103774 \\
\hline 03 & Informática & 000000000000023714 & SERVIDOR INTEL & 103774 \\
\hline 03 & Informática & 000000000000023714 & SERVIDOR INTEL & 103774 \\
\hline 03 & Informática & 000000000000024428 & $\begin{array}{l}\text { PLACA ADPTDR } \\
\text { FRIBRE CHANNEL }\end{array}$ & 156160 \\
\hline 03 & Informática & 000000000000025353 & $\begin{array}{l}\text { TRILHO BASTIDOR } \\
\text { SERVIDOR }\end{array}$ & 103774 \\
\hline 06 & Transmissão & 000000000000600456 & $\begin{array}{l}\text { COMBINADOR } \\
\text { REDE ANTENAS }\end{array}$ & 134758 \\
\hline 06 & Transmissão & 000000000000600448 & $\begin{array}{l}\text { UNIDADE FAN } \\
\text { FANU }\end{array}$ & 134753 \\
\hline 08 & Telefonia Móvel & 000000000000600412 & $\begin{array}{l}\text { PLACA } \\
\text { CONTROLADORA } \\
\text { DE FAN - FACB }\end{array}$ & 134753 \\
\hline 08 & Telefonia Móvel & 000000000000600452 & $\begin{array}{l}\text { MÓDULO 9100 } \\
\text { UNIDADE } \\
\text { ESTAÇÃO }\end{array}$ & 134753 \\
\hline
\end{tabular}




\begin{tabular}{|c|c|c|c|c|}
\hline 06 & Transmissão & 000000000000600456 & $\begin{array}{l}\text { COMBINADOR } \\
\text { REDE ANTENAS }\end{array}$ & 134753 \\
\hline 08 & Telefonia Móvel & 000000000000600450 & $\begin{array}{l}\text { UNIDADE } \\
\text { CONVERSORA AC } \\
\text { PM12 }\end{array}$ & 134753 \\
\hline 06 & Transmissão & 000000000000600415 & $\begin{array}{l}\text { PLACA } \\
\text { TRANSCEPTORA } \\
\text { TRX1800 EDGE }\end{array}$ & 134753 \\
\hline 06 & Transmissão & 000000000000600413 & $\begin{array}{l}\text { PLACA } \\
\text { TRANSCEPTORA } \\
\text { TRX1800 HP EDGE }\end{array}$ & 134753 \\
\hline 08 & Telefonia Móvel & 000000000000600462 & $\begin{array}{l}\text { GRUPO SWITCH } \\
\text { SWCH GS }\end{array}$ & 134753 \\
\hline 08 & Telefonia Móvel & 000000000000600463 & $\begin{array}{l}\text { ACESSO SWITCH } \\
\text { SWCH AS }\end{array}$ & 134753 \\
\hline 08 & Telefonia Móvel & 000000000000600460 & $\begin{array}{l}\text { SUPRIMENTO } \\
\text { ENERGIA BSC } \\
\text { DCDC 3BK30606AA }\end{array}$ & 134753 \\
\hline 08 & Telefonia Móvel & 000000000000600446 & $\begin{array}{l}\text { PROCESSADOR } \\
\text { TCUC }\end{array}$ & 134753 \\
\hline 08 & Telefonia Móvel & 000000000000600447 & $\begin{array}{l}\text { PROCESSADOR } \\
\text { DTCC } 75 \text { OHM }\end{array}$ & 134753 \\
\hline 06 & Transmissão & 000000000000600416 & $\begin{array}{l}\text { PLACA } \\
\text { TRANSCODER } \\
\text { TC A925 P/1 ATER }\end{array}$ & 134753 \\
\hline 08 & Telefonia Móvel & 000000000000600454 & $\begin{array}{l}\text { INTERFACE BIUA } \\
75 \text { OHM }\end{array}$ & 134753 \\
\hline 06 & Transmissão & 000000000000600448 & $\begin{array}{l}\text { UNIDADE FAN } \\
\text { FANU }\end{array}$ & 134751 \\
\hline 08 & Telefonia Móvel & 000000000000600450 & $\begin{array}{l}\text { UNIDADE } \\
\text { CONVERSORA AC } \\
\text { PM12 }\end{array}$ & 134751 \\
\hline 06 & Transmissão & 000000000000600459 & $\begin{array}{l}\text { UNIDADE ÁREA } \\
\text { CONEXÃO COMP } \\
\text { OUTDOOR }\end{array}$ & 134751 \\
\hline 03 & Informática & 000000000000022003 & $\begin{array}{l}\text { MÁQUINAS E } \\
\text { APARÊLHOS } \\
\text { IMPRESSÃO }\end{array}$ & 135163 \\
\hline
\end{tabular}

Figura 3.13 Lista dos Materiais (itens), por fornecedor ou tipo.

As simbioses listadas na Tabela 3.14 apresentam algumas particularidades importantes. Em primeiro lugar é preciso diferenciar a reciclagem que ocorre pelo descarte de produtos após consumo daqueles que são descartados por deficiências durante a fabricação ou pouco após a venda, quando ainda se encontram na garantia. Para o primeiro caso, não se encontrou interações entre as empresas listadas na Tabela 3.14.

Para se verificar as possíveis razões para não ocorrerem tais interações, customizou-se o SAP R/3 para controlar a comercialização de materiais reciclados, configurando-se corretamente os impostos como prevê a legislação. Assim, a venda e a 
revenda dos produtos geram alto custo e inibem o processo, independentemente da distância entre os pontos de coleta e reciclagem ou do custo dessa coleta. Isto é facilmente comprovado porque o sistema emite "todas" as notas fiscais com os créditos de impostos relacionados ao tipo de material movimentado.

Quatro variáveis são consideradas quando da implantação de ecossistemas industriais: viabilidade técnica, econômica, estrutura organizacional e permissão legal e/ou regulatória (STANLEY, 1999) e (AYRES, 1994). No presente caso a questão técnica parece resolvida, pois há semelhanças entre os produtos comercializados e reciclados, provavelmente a estrutura organizacional não seria um grande problema, porque as empresas pesquisadas têm histórico de controle rígido de emissões e planos de redução de resíduos, ou seja, há tradição na avaliação de substâncias presentes no processo produtivo, porém a questão regulatória mostrou-se de grande importância. Isso está de acordo com o exemplo citado por Silva (2004) de que "pilhas e baterias são recicladas e/ou descartadas no país pelos seus produtores, qual a exigência que se fará às importadas?". Portanto, estes dados sugerem que a atuação das associações se faz necessária e, se bem coordenado, um esforço desse tipo pode aumentar a competitividade da empresa nacional.

Supondo-se que o ecossistema industrial prescinda de custos advindos do pagamento de impostos, e supondo as distâncias médias existentes entre as empresas existentes no estado de S. Paulo, alguns ecossistemas tornam-se possíveis. A utilização de resíduos de PCI já foi abordada anteriormente, mas a diferença neste caso é a uniformidade do produto, que implica no melhor controle da composição e a possibilidade de sugerir outros meios de reciclagem, tais como a indústria de eletroeletrônicos, devido aos componentes presentes na placa e à modularização. Do mesmo modo, o aumento de volume de produção, pode favorecer a reciclagem dos metais.

No caso das indústrias de base, como é a indústria química, no SAP R/3 o controle é feito por etapa de processo, o que permite efetuar-se o balanço de massa para obter-se o percentual de refugo. Para o reuso de metais o resultado final obtido é semelhante ao descrito para a torre de transmissão: pouco produto é perdido no produtor 
(menos de 10\% de refugo, totalmente aproveitado). Contudo, deve-se observar que o uso dos metais presentes internamente aos componentes não é pratica corrente.

Assim de modo geral, a reciclagem de equipamentos pós-uso apresenta várias dificuldades, mesmo quando o produtor se encarrega desta reciclagem.

\subsubsection{2 reciclagem de computadores e celulares}

Equipamentos que apresentam pequeno tamanho normalmente não podem prescindir da tecnologia de montagem em superfície e, de modo geral, celular e/ou computador é um bom exemplo desse uso. Portanto, fez-se uma simulação de dados referentes a fabricação de computares e celulares e a Tabela 3.15 mostra o resultado da simulação desses produtos no sistema, destacando-se a massa de cada componente, obtida de modo similar ao descrito no item anterior. No presente caso deu-se ênfase também à toxidade, o que influi fortemente na possibilidade de reciclagem, e à análise de custos, estimando-se o ganho econômico. Por fim, observe-se que a situação descreve partes e peças e interação direta entre empresas.

Tabela 3.15 Percentual em massa de co-produtos presentes em componentes eletroeletrônicos.

\begin{tabular}{|c|c|c|}
\hline Co-produtos & $\begin{array}{c}\text { Percentual em massa no } \\
\text { Celular }\end{array}$ & $\begin{array}{c}\text { Percentual em massa no } \\
\text { Computador }\end{array}$ \\
\hline Polímeros orgânicos & 46 & 23 \\
\hline Chumbo & 0,9 & 7 \\
\hline Alumínio & 9 & 21 \\
\hline Ferro & 8 & 1 \\
\hline Estanho & 1 & 7 \\
\hline Cobre & 19 & 0,8 \\
\hline Níquel & 1 & 2,2 \\
\hline Zinco & 3 & 0,02 \\
\hline Prata & 0,9 & 25 \\
\hline Sílica & 4 & 0,01 \\
\hline Mercúrio & 1 & \\
\hline & &
\end{tabular}


No processo de reciclagem nem todo o co-produto descartado pode ser reaproveitado, portanto a Tabela 3.15 mostra apenas o percentual de componentes que pode ser reciclado. Assim, supondo-se o máximo rendimento possível, especialmente para os metais, estimou-se o percentual de reaproveitamento, como pode ser visto na Tabela 3.16

Tabela 3.16 Percentual de reaproveitamento médio de coprodutos presentes em componentes eletroeletrônicos.

\begin{tabular}{|c|c|}
\hline Coprodutos & $\begin{array}{c}\text { Percentual de } \\
\text { reaproveitamento }\end{array}$ \\
\hline Polímeros orgânicos & 12 \\
\hline Chumbo & 12 \\
\hline Alumínio & 8 \\
\hline Ouro & 1 \\
\hline Cádmio & 1 \\
\hline Aço & 8 \\
\hline Prata & 1 \\
\hline Mercúrio & 1 \\
\hline
\end{tabular}

Comparando-se o valor da reciclagem, isto é, o custo obtido por esta via, o valor da matéria-prima, obtém-se aproximadamente o valor de ganho econômico na implantação do sistema. O processo é vantajoso, ou seja, o custo de material reciclado não excede o de compra de matéria-prima na maioria das vezes. Assim, por exemplo, a reciclagem de uma tonelada de computadores permite a obtenção de cerca de $100 \mathrm{~kg}$, o resulta em um rendimento global de $10 \%$, este valor é maior para alguns componentes, como o chumbo, e menor para outros, como ouro. A Tabela 3.17 apresenta a provável massa reciclada de componentes em uma tonelada de computadores. Como mostra a tabela, certos componentes são recuperados em pequena percentagem, como o ouro, no entanto a pureza do metal a ser recuperado é de grau eletrônico.

Tabela 3.17 Massa reciclada de componentes em uma tonelada de computadores

\begin{tabular}{|c|c|}
\hline Componentes & Matéria Prima Reciclada \\
\hline Polímeros & $52,9 \mathrm{~kg}$ \\
\hline Alumínio & $4,1 \mathrm{~kg}$ \\
\hline Chumbo & $28,7 \mathrm{~kg}$ \\
\hline Ouro & $0,002 \mathrm{~g}$ \\
\hline
\end{tabular}




\begin{tabular}{|c|c|}
\hline Prata & $0,04 \mathrm{~g}$ \\
\hline Aço & $13,23 \mathrm{~kg}$ \\
\hline Cádmio & $0,01 \mathrm{~g}$ \\
\hline Mercúrio & $0,022 \mathrm{~g}$ \\
\hline
\end{tabular}

Assim, não só o ganho econômico é importante, mas também o ambiental. Ambientalmente a reciclagem é extremamente vantajosa, mesmo que a recuperação da matéria prima não seja completa, já que alguns materiais que compõe os eletroeletrônicos advêm de matéria-prima não renovável, como os polímeros orgânicos, alguns metais são bastante tóxicos, como mercúrio e chumbo e, na maioria das vezes, o descarte em aterro controlado implica em ciclo de centenas de anos ou mais, contra o baixo ciclo de vida de eletroeletrônicos, como o computador que é em média de 4 anos ou do celular, que é de dois anos.

Para estimar o provável crescimento de reutilização advindo da reciclagem, buscaram-se dados de empresas que já empregam o conceito de Ecologia Industrial há algum tempo. Observou-se que em metalúrgicas (como a descrita anteriormente) percentual de co-produtos que foi destinado aumentou continuamente após a implantação do conceito. Assim, no ano seguinte à implantação, a geração cresceu em $52 \%$ e a destinação em 84\%, e nos anos seguintes a parte de coprodutos destinados foi ainda maior, como a borra de chumbo e de zinco com $100 \%$ e a lamilha de prego com $98 \%$ de destinação. Portanto, o tempo de uso e a maturidade do sistema são fatores determinantes, mas provavelmente se implantados em relação à sucata no país, levará a ganho ambiental e econômico em curto prazo.

Os resultados obtidos foram comparados às propostas veiculadas pelas associações e governos no que concerne ao lixo eletrônico ou $e$-waste. (Commonwealth of Austrália, 1996) (Integrated Waste Management Board, 2004). As respostas obtidas mostraram-se concordantes com as propostas da maioria das associações, o que demonstra a grande potencialidade do uso de software para assistir a formação de ecossistemas industriais. É importante observar que a maioria das recomendações das associações é no sentido de reciclagem do $e$-waste.

\subsubsection{O Aspecto Social}


Este item discute genericamente o aspecto social, uma vez que a sustentabilidade presume considerar o tripé aspectos ambientais/econômicos/sociais.

Há diferentes abordagens, como visto nos aspectos teóricos, para os aspectos sociais, ou mesmo para a definição de responsabilidade social (LAURINO, 2006) e (BOVO, 2003). Algumas são atendidas pelas normas internacionais de segurança e saúde no trabalho, como as da OSHA (Occupational Safety and Health Administration), que possui as suas contrapartidas nas normas brasileiras, porém tais normas têm como característica uma grande preocupação com o controle de indicadores pós ocorrência de algum fato ou de alguma não conformidade, tais como acidentes. Por outro lado a idéia da responsabilidade social é uma questão mais ampla, pois fornece também indicadores de caráter preventivo que visam em última análise uma melhor qualidade de vida, para atingir-se a sustentabilidade de acordo com a Agenda 21.

Este trabalho optou por verificar a adaptação aos indicadores da norma SA 8000 (FELIPE, 2001) por esta ser uma norma até mais ampla que as normas de segurança e saúde no trabalho. Normas de segurança do trabalho normalmente preocupam-se com apenas uma fração do empreendimento, ou seja, o empregado, enquanto a SA 8000 é mais ampla e preocupa-se também com o entorno, por meio de indicadores sociais externos e ambientais. Portanto a SA 8000 está mais perto da definição de responsabilidade social e de sustentabilidade e os seus indicadores estão mais de acordo com a proposta deste trabalho e mais adequados à definição de sustentabilidade.

É importante observar que se avaliando a aplicação de uma norma de sobre aspectos sociais também se obtêm subsídios sobre a aplicabilidade em sistemas de gestão, tais como o sistema de gestão integrado.

O procedimento utilizado para verificar vantagens e desvantagens pela aplicação da norma foi como segue:

- Definição os indicadores que devem ser obtidos;

- Avaliação da possibilidade de obtenção dos indicadores via software;

- Avaliação do uso de outro sistema que não o software em questão;

- Simulação da obtenção dos indicadores para uma empresa de grande porte

- Simulação da obtenção dos indicadores para uma empresa de pequeno porte, sem o uso do software. 
- Comparação dos resultados.

Em grandes empresas do setor eletroeletrônico, como comentado anteriormente, o sistema SAP R/3 é comum. Porém, como também já observado, pequenas empresas costumam não possuir software de controle. Assim, dividiu-se o problema entre pequenas e grandes empresas.

Quanto aos indicadores a serem obtidos: Após a definição da norma a ser atendida buscou-se no país algum órgão que estivesse sugerindo mecanismos de aplicação para operacionalização desta norma. Dentre os possíveis órgãos encontram-se os seguintes: $\mathrm{O}$ Ethos, uma ONG que, como o CEBDS (Conselho Empresarial Brasileiro para o Desenvolvimento Sustentável), a criação e manutenção são de responsabilidade primordialmente do setor empresarial, criou algumas regras para a aplicação da SA 8000. Institutos, como o IBES (Instituto Betinho de Sustentabilidade), criaram diferentes sugestões, como o formulário para a verificação da situação de responsabilidade social de um empreendimento. Dentre as possibilidades utilizou-se a proposta do IBES como base para o estudo da SA 8000, devido à abrangência dos indicadores citados por este instituto. O formulário de proposta para a SA 8000 do IBES encontra-se no Anexo 7.

Avaliação da possibilidade de uso e obtenção dos indicadores via software para grandes empresas: o software em questão possui todos os dados requisitados pelo formulário proposto pelo IBES em um módulo conhecido como HR (Human Resources). Assim, a obtenção dos indicadores é direta, sem necessitar de praticamente nenhuma customização.

Simulou-se o tempo total empreendido para obtenção dos indicadores em uma grande empresa. A simulação foi comparada a estimativa de especialistas, conseguida através de entrevistas com profissionais de RH (recursos humanos). De modo geral, os resultados mostram que é possível a avaliação da aplicação das normas com até 0,5 homens hora por funcionário da empresa. O tempo é aparentemente alto porque o sistema exige o preenchimento de uma série de campos obrigatórios que não são relevantes para os indicadores da sustentabilidade, mas que ocorre quando o profissional é admitido na empresa. 
Avaliação da possibilidade de uso e obtenção dos indicadores via software para pequenas empresas: como normalmente estas não possuem sistemas de controle via software, consultaram-se três especialistas para verificar quais seriam as melhores possibilidades de obtenção dos indicadores selecionados. As respostas foram conseguidas com funcionários de grandes empresas, por meio de entrevista, abordando três questões, definidas na Tabela 3.18. Por fim, avaliou-se também qual o melhor modo de manipular tais informações. Os especialistas foram unânimes em sugerir um banco de dados, como SQL.

Nas entrevistas realizadas de acordo com o descrito na Tabela 3.18 também se concluiu que o preenchimento dos dados deve ser feito por um funcionário qualificado, em lugar de obterem-se dados via cadastro efetuado pessoalmente pelos empregados. Isto decorre do treinamento indispensável além da eventual necessidade de restringir o acesso a um banco de dados por empregados de níveis mais operacionais.

Tabela 3.18 Questões para a aquisição de Dados

\begin{tabular}{|l|l|}
\hline Questão & Entrevistado \\
\hline $\begin{array}{l}\text { Possibilidade do preenchimento on-line por } \\
\text { todos os funcionários de uma pequena } \\
\text { empresa e confiabilidade dos dados. }\end{array}$ & $\begin{array}{l}\text { Funcionário de recursos humanos, analista } \\
\text { funcional }\end{array}$ \\
\hline $\begin{array}{l}\text { Tempo estimado para o levantamento das } \\
\text { informações e preenchimento do cadastro } \\
\text { por um funcionário de RH. }\end{array}$ & Funcionário de recursos humanos \\
\hline $\begin{array}{l}\text { Estimativa de tempo para geração de } \\
\text { indicadores }\end{array}$ & Analista funcional \\
\hline
\end{tabular}

De modo geral, os especialistas também consideram que as informações relevantes para a aplicação da norma já estão arquivadas pela empresa, e podem ser mais facilmente levantadas pela área de recursos humanos, pois os dados requisitados já foram informados no ato da contratação, no currículo e na folha de pagamento e é de responsabilidade do RH sumaria-las.

Simulação da obtenção dos indicadores, e comparação dos resultados, para empresa de pequeno e grande porte: como tanto na pequena como na grande empresa, na opinião de especialistas, a responsabilidade do cadastramento fica definida como do RH, 
pode-se estimar o tempo necessário para a aquisição e cadastro dos dados nos dois sistemas.

Para avaliar o esforço de obtenção destes indicadores foi feito um teste, que correspondeu a cadastrar dez funcionários em cada um desses sistemas. Para a pequena empresa escolheu-se a base SQL porque esta é compatível com Windows® e Linux® além de ter licença gratuita. Na estimativa foi usado como base o MysqlFont@, que permite a manipulação de muitos dados e o envio de grandes arquivos. A Tabela 3.19 mostra os resultados obtidos quanto ao tempo de cadastro, o tempo de preenchimento e a forma como os indicadores são gerados.

Tabela 3.19 Comparativo entre o SAP e o SQL (MysqIFont $\left.{ }^{\circledR}\right)$ para cadastro de dados relevantes para o balanço social

\begin{tabular}{|l|c|c|}
\hline & SAP & SQL (MysqlFont $\left.{ }^{\circledR}\right)$ \\
\hline $\begin{array}{l}\text { Tempo de Cadastro para o } \\
\text { primeiro funcionário de } \\
\text { cada cargo }\end{array}$ & $3 \mathrm{~h} / \mathrm{h}$ & $1,5 \mathrm{~h} / \mathrm{h}$ \\
\hline $\begin{array}{l}\text { Tempo de cadastro para os } \\
\text { demais funcionários }\end{array}$ & $0,5 \mathrm{~h} / \mathrm{h}$ & $1 \mathrm{~h} / \mathrm{h}$ \\
\hline Responsabilidade & \multicolumn{1}{|c|}{ Analista Funcional } & $\mathrm{RH}$ \\
\hline Geração de indicadores & $\begin{array}{l}\text { Instantânea, Quantitativa e } \\
\text { Gráfica }\end{array}$ & $\begin{array}{l}\text { Instantânea, Quantitativa; e } \\
\text { possivelmente Gráfica }\end{array}$ \\
\hline
\end{tabular}

Pela Tabela 3.19 verifica-se que o tempo do primeiro cadastro é maior no SAP, pois este sistema exige o preenchimento de uma série de campos obrigatórios, que não são relevantes para os indicadores da sustentabilidade, enquanto o MysqlFont ${ }^{\circledR}$ é um banco de dados para cadastro das informações relevantes, o que gera o menor tempo no primeiro cadastro. Entretanto observa-se que no SAP o tempo cai para o cadastro dos demais funcionários, devido à funcionalidade de criação de cadastro com cópia no modelo já efetivado, para o MysqlFont ${ }^{\circledR}$ esta cópia deve ser feita manualmente. Como o sistema de grande porte exige o conhecimento das transações corretas, o cadastro deve ser feito por um analista; no banco de dados as informações são solicitadas diretamente, facilitando a entrada de dados, porém as informações necessárias estão segmentadas na empresa e cabe ao funcionário de recursos humanos sumaria-las. O SAP apresenta os indicadores de maneira gráfica e o MysqlFont ${ }$, se configurado, apresenta de maneira gráfica desde que alguma interface seja ativada para isto. Para o SAP necessita-se de 
conhecimento funcional do cadastro, já o banco de dados é mais simples de ser preenchido, contudo não gera instantaneamente os resultados gráficos.

Por extrapolação, devido ao bom resultado obtido nos dois casos, pode-se ver a utilidade do uso de software para implantação de sistemas de gestão e também para a extração e organização de dados necessários para a avaliação da sutentabilidade, conforme a planilha elaborada a partir de indicadores propostos, por exemplo, pela BOVESPA e que são listados no Anexo 1.

\subsubsection{O Aspecto Econômico}

A aplicação do conceito de Ecologia Industrial via software com o uso de BSC, como aqui proposto, é altamente dependente da geração de relatórios. Do mesmo modo, a implantação de sistemas, como a SA 8000, ou de indicadores, como da BOVESPA, exige auditorias constantes, que também são dependentes da geração de relatórios. Assim, foi verificado, via estudo de caso, qual a influência econômica da geração de relatórios via software. Assim sendo um estudo de caso foi efetuado considerando o impacto econômico na implantação da funcionalidade do Business Warehouse.

A empresa do estudo de caso é provedora de serviços de telecomunicações e para oferecer este serviço possui centrais de transmissão de dados que foram montadas com diferentes produtos do setor em avaliação, o eletroeletrônico. A geração de relatórios é necessária para atender vários stakeholders, em auditoras freqüentes. O principal stakeholder, neste caso, são acionistas e financiadores. Para a empresa em questão, um info cubo foi gerado e a Figura 3.14 mostra as etapas de sua construção. Primeiramente os dados relevantes são rastreados no $\mathrm{R} / 3$ e suas respectivas tabelas são listadas. Um programa denominado extrator ABAP busca estes dados nos campos determinados e os leva para um info objeto, denominado Datasource genérico.

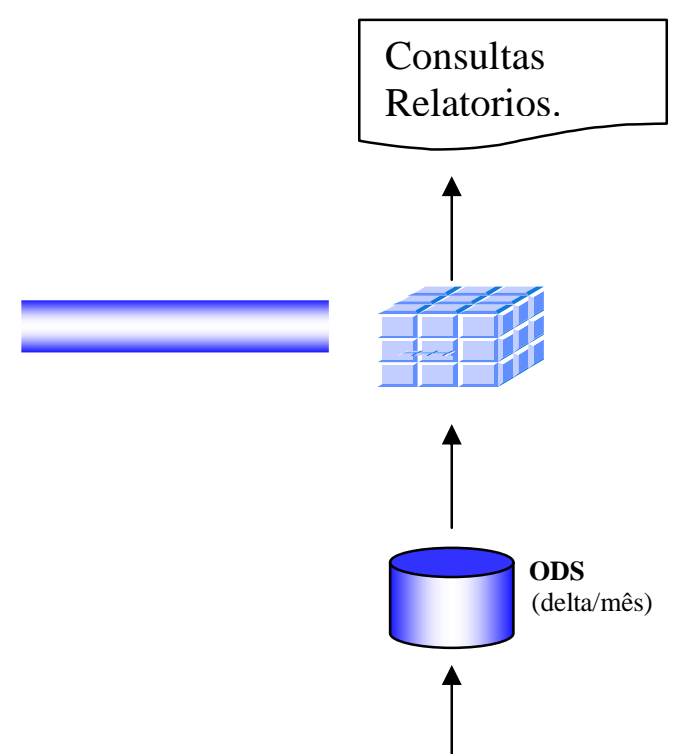




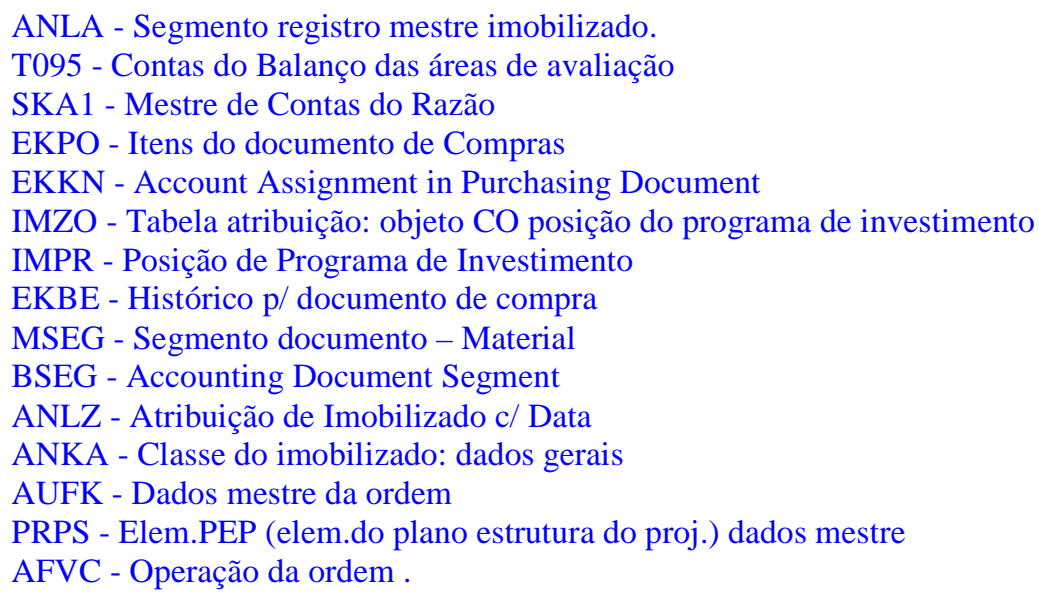

Figura 3.14 Esquema da extração de dados para formação de um info cubo

Com todos os dados no info objeto a ODS (Operational Data Storage) faz a organização dos dados. Nesta ODS tem-se toda a granularidade, com toda a hierarquia, textos e atributos dos campos contidos nas tabelas do R/3. Com a organização e a filtragem dos dados feita pela ODS o cubo é formado. No cubo a agregação de dados é permitida gerando um acumulado que pode ser comparado com uma meta estipulada.

Os cubos formados geram relatórios, sendo que as variáveis do relatório são selecionáveis como mostra a Figura 3.15. 


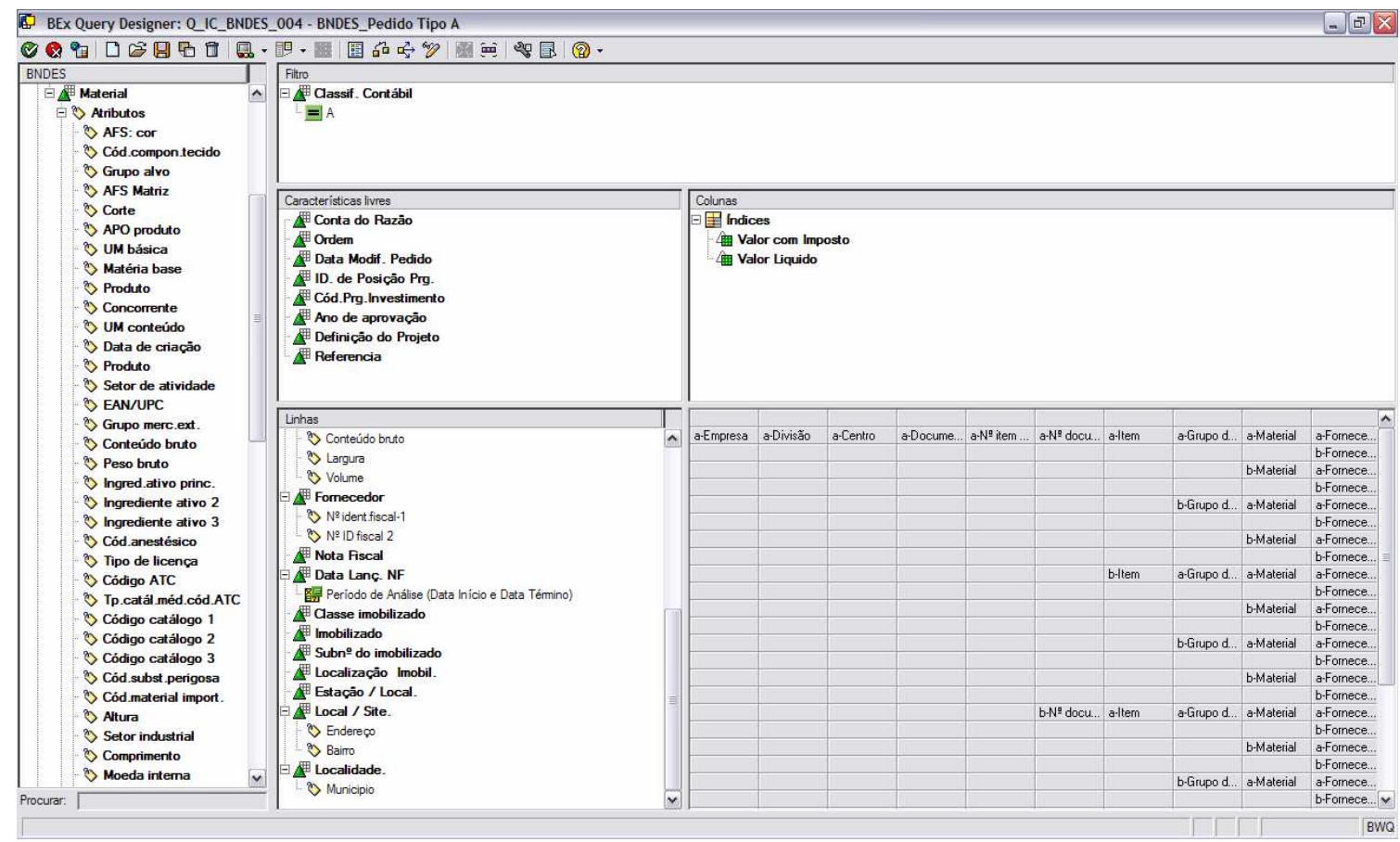

Figura 3.15, Seleção De Variáveis Para A Geração De Relatório.

Observe, na Figura 3.15, que muitos atributos do material podem ser obtidos em um relatório on-line, atendendo aos preceitos do LCI como a metodologia para implantação do conceito de Ecologia Industrial. Os relatórios gerados possuem dados que podem alimentar indicadores do BSC.

Os resultados diretos da implantação da funcionalidade são sumariados a seguir.

Para a geração de relatórios as principais melhorias de processo foram:

- Redução de uma equipe de 12 pessoas, necessárias em um período de até 45 dias para a geração de relatórios sem definição de padrão. Essa equipe era composta por um gerente financeiro, dois analistas e dez programadores, resultando em redução de investimento de US\$ 50.000 no ano por visita do fiscal, que tem histórico de até três visitas anuais. Assim, a redução pode chegar a US\$150.000 por empresa. Considerando que o grupo tem duas empresas (Empresa de telecomunicações Itelefonia celular) participando do programa de Investimento, o ganho anual é na ordem de US\$300.000;

- Redução de dois gerentes financeiros para acompanhar a análise da programação (US\$ 30.000), eliminação do custo relativo à programação na ordem US\$90.000, 
eliminação do custo de manutenção relativo a sistemas legados em Access (US\$ 20.000), resultando em economia de US\$140.000 anuais;

- A informação estava estática, fragmentada e não real-time no nível gerencial, porém, com o BW o tempo de análise não ultrapassa em 4 horas mensais, com uma eficiência de ganho de US\$90.000;

- A consolidação da informação e o acesso em tempo-real colaboram no suporte estratégico à decisão (atendimento ao fisco, acompanhamento dos investimentos custos/orçamento, correspondendo a uma economia de US\$350.000 anuais).

A situação da Empresa antes e depois da consolidação de dados na Empresa é resumida qualitativamente na Tabela 3.20.

Tabela 3.20: Resumo Da Situação Da Empresa De Telecomunicações Antes E Depois Da Consolidação De Dados

\begin{tabular}{|c|c|}
\hline Situação anterior à consolidação & Situação posterior à consolidação \\
\hline $\begin{array}{l}\text { - Cada auditor, em suas visitas, diferentes } \\
\text { informações sem definição padrão. Para } \\
\text { essas informações é necessária a geração } \\
\text { de aproximadamente } 260 \text { relatórios. } \\
\text { - Relatórios solicitados ficam disponíveis } \\
\text { para os auditores em aproximadamente } 45 \\
\text { dias; } \\
\text { - Vários sistemas fragmentados de finanças } \\
\text { (em Access e Excel) sem integração com o } \\
\text { SAP; } \\
\text { - Relatórios inflexíveis; } \\
\text { - Utilização de uma grande equipe em um } \\
\text { grande período de tempo; } \\
\text { - Manutenção de sistemas legados em } \\
\text { Access; } \\
\text { - Informação estática. }\end{array}$ & $\begin{array}{l}\text { - Criou-se uma única e consolidada base de } \\
\text { dados que melhorou visivelmente os } \\
\text { relatórios e agilizou sua geração(baseados } \\
\text { em imobilizados, ordens internas, } \\
\text { diagrama de rede e elemento PEP); } \\
\text { - Viabilizou todo e qualquer tipo de geração } \\
\text { de relatórios para uso de auditorias; } \\
\text { - Fácil consolidação e acesso real-time das } \\
\text { informações. } \\
\text { - Missão do estudo de caso foi cumprida } \\
\text { utilizando banco de dados já existente. }\end{array}$ \\
\hline
\end{tabular}

Portanto, a modelagem de dados usada com a plataforma BW pode ser utilizada para a avaliação da perspectiva econômica, como princípio da Ecologia Industrial e conseqüentemente do desenvolvimento sustentável.

\subsection{Propostas Para As Pequenas E Médias Empresas}


A aplicação do conceito de Ecologia Industrial pode ser por setor, identificandose oportunidades de melhorias ambientais, de formação de ecossistemas industriais, etc. No presente caso, o setor eletroeletrônico, devido ao alto valor agregado de seus produtos, compõe-se em uma boa oportunidade e o trabalho efetuado mostrou que no país vantagens ambientais, econômicas e sociais podem efetivamente ocorrer.

De modo geral observou-se que o início e fim da cadeia podem se beneficiar enormemente da existência de software de controle complexos, como o SAP R/3 e, como grandes empresas atuam nesses ramos da cadeia, não é difícil que tal ocorra. No meio da cadeia o uso de sistemas mais simples, como o questionário - em planilha Excel - e montagem de um BSC com poucas informações, que foi a metodologia aplicada nas empresas que compõem a ABRACI, é eficiente. Essa estratégia é especialmente útil quando se trata de o preenchimento de questionários mais simples, como os requeridos para classificação de sustentabilidade de acordo com os requisitos da BOVESPA ou o balanço social como o sugerido pela SA 8000 . Esta estratégia, neste trabalho, foi testada pelo preenchimento de um banco de dados MysqlFont.

Os estudos de caso mostraram que o software de ERP fornece os dados de toda a movimentação dos insumos usados na produção, no entanto para os indicadores de performance ambiental o mais relevante são as informações constantes de poucos módulos, especialmente o módulo de recursos humanos e os dados mestres de materiais. A obtenção dos dados na área de recursos humanos pode ser efetuada por qualquer profissional da área e os principais indicadores, necessários para implantação do conceito, são sumariados a seguir:

Mestre de Fornecedores: Cadastro da localização, dos dados bancários e outras informações dos fornecedores usados nos pedidos de compras. Estes parâmetros são essenciais para o cálculo do custo do transporte.

Mestre de Clientes: Semelhante aos dados dos fornecedores, no entanto estes dados são usados nas ordens de venda. Parâmetros necessários para a estimativa da necessidade planejada e para o cálculo do custo de transporte.

Mestre de Materiais: Cadastro de todos os materiais que entram e saem da empresa, com o estoque e valor atualizado. Informações relevantes para a Ecologia Industrial, como localização do material e toxidade. 
Lista Técnica de Componentes: Disponibiliza a lista de insumos usados na produção de um material. Informações relevantes para o ACV.

Mestre de Funcionários: Dados cadastrais de cada funcionário, este disponibiliza informações relevantes para o balanço social, conforme a SA 8000.

Dados de impostos: Taxas de impostos por região para o cálculo do custo da comercialização de co-produtos em comparação com o descarte de resíduos

Contudo, no Brasil, grande parte da produção é realizada por empresas de médio e pequeno porte e para estas é inviável o uso de software desenvolvido para grandes empresas, como o SAP, comum em empresas com faturamento anual mínimo de 10 milhões ao ano. Além disso, a implantação e manutenção destes sistemas são extremamente custosas.

Em empresas de menor porte políticas de gestão ambiental são raras e, de modo geral, o desperdiço é maior, a responsabilidade social e ambiental pequenas. Considerando que pequenas e médias empresas empregam cerca de $60 \%$ dos trabalhadores, o impacto social destas é grande. Portanto encontra-se nesta parte do setor produtivo um nicho de mercado a ser explorado com a implantação de políticas de gestão sustentável.

Portanto, bases de dados mais acessíveis foram pesquisadas como alternativas, por exemplo, DataSul e SQL. Para o SQL foi estimado o custo para montar-se um sistema de gestão sustentável com base nos resultados deste estudo. Esta base foi escolhida porque é compatível com Windows® e Linux ${ }^{\circledR}$, além de ter licença gratuita. Para tanto, profissionais de informática foram consultados para a elaboração de um software que contivesse as informações listadas anteriormente e estimou o custo aproximado em R\$ 4000.

\subsection{Conclusão}

Este trabalho selecionou estudos de caso que relatam uma implantação diferenciada, nesta o sistema de Data Warehouse foi direcionado para uma aplicação inovadora, o atendimento do conceito de Ecologia Industrial. Normalmente este sistema é 
usado para geração de relatórios gerenciais assistindo à tomada de decisões e definições de estratégias. Durante esta pesquisa verificou-se que outras vantagens podem ser exploradas, como o monitoramento da performance de funcionários e equipamentos. Esta ferramenta, mesmo que analítica, consiste em relevante apoio ao processo de tomada de decisão e construção de um plano de ação.

Com a disponibilidade da informação do fluxo de materiais on-line, ecossistemas industriais podem ser elaborados, redirecionando o refugo da produção para outras fábricas que possam reutilizá-los, estimulando a Ecologia Industrial e a Produção Limpa; para tanto, precisam-se de evoluções legislativas como o incentivo fiscal, facilitando o trânsito destes materiais. 


\section{CONCLUSÃO E TRABALHOS FUTUROS}

Para o mundo atual é necessária a mudança de paradigmas e entre as mudanças mais prementes encontra-se a necessidade de garantir a sustentabilidade dos empreendimentos humanos. Assim, a gestão empresarial tende a mudar e, para adequarse a essa nova forma de gestão, o conceito de Ecologia Industrial e o uso de softwares de controle podem ser de grande valia.

O presente trabalho teve como objetivo desenvolver metodologia do uso desses softwares de modo encontrar indicadores de sustentabilidade adequados e possíveis melhorias de processo. Através dos estudos de caso desenvolvidos observou-se não só que softwares de controle podem ser adequados para a implantação do conceito de Ecologia Industrial como também que podem mostrar vantagens ambientais, econômicas e sociais. Assim, são vantagens implícitas da aplicação destes softwares a avaliação dos empreendimentos de acordo com normas de gestão, como as Normas ISO, ou de sustentabilidade empresarial, como as do BOVESPA.

Os ecossistemas industriais, expressão máxima do conceito de Ecologia Industrial, podem ser aplicados a empreendimentos distintos que se encontram fisicamente próximos ou a um setor de produtivo. Até o momento não se encontrou informações da análise do setor eletroeletrônico para a formação de ecossistemas industriais. Portanto, este setor foi aqui preliminarmente avaliado e apresentou várias oportunidades de redução de custos na cadeia produtiva devido à reutilização de coprodutos gerados internamente ou por outras empresas, sugerindo um esforço para aumentar a formação de ecossistemas industriais neste setor. Como a formação de ecossistemas industriais é muito dependente da troca, é relevante o fato dos estudos de caso mostrarem a importância das distâncias e, deste modo, entre os prováveis impactos significativos, a emissão de carbono precisa ser fortemente considerada.

Algumas dificuldades de formação de parcerias para estabelecer ecossistemas, mesmo que incipientes, foram encontradas. Interessantemente tais dificuldades são bastante semelhantes às encontradas em outros eco-parques e descritas na literatura. Assim, a categorização de certos materiais necessariamente como resíduos dificulta sua comercialização e, por conseqüência, seu reuso ou reciclagem principalmente por 
questões econômicas, devido à tributação. A mudança de definição destes materiais significaria uma diminuição significativa no custo e, provavelmente, um aumento nas trocas entre empresas. Caso a categorização não fosse mudada, uma reavaliação das normas permitindo-se que o CADRI (Certificado de Aprovação de Destino de Resíduos Industriais) não seja necessário, ou que ele possa ser obtido em conjunto, como foi aprovado para as escolas $\mathrm{SENAI}^{4}$, pode facilitar a obtenção de ecossistemas.

Além do aspecto legal, também a importância das associações de classe para a facilitação do processo de trocas entre empresas é grande. Assim, estas empresas podem agir no intuito de categorizar os co-produtos de seu setor ou área e favorecer a formação de ecossistemas. A atuação das associações pode ser expressiva também para comprovar que o setor é ambientalmente mais correto que os competidores externos, exigindo salvaguardas das autoridades para seus produtos. Assim, uma meta de longo prazo poderia ser a criação de um selo que descreveria a empresas como constituinte de um ecossistema, o que facilitaria as trocas de materiais sem encargos e a obtenção de salvaguardas.

O uso de software para a aplicação do conceito de Ecologia Industrial não necessariamente significa o uso de software de alto custo. Muitas empresas de serviços ou de produção, principalmente as pequenas, não possuem sistemas de gestão de recursos, e são raras as que têm uma política de sustentabilidade. Portanto as funcionalidades do software estudado, que se mostraram relevantes para a aplicação das ferramentas da Ecologia Industrial, SA8000, etc. foram destacadas e buscou-se a possibilidade do uso de banco de dados de livre acesso para empresas de pequeno porte. Assim, a formação de um relatório simples (BSC) pode ser de grande valia para a sustentabilidade.

A geração destes relatórios simples pode ter uma série de vantagens. Os relatórios refletem dados customizados e atualizados e ajudam os gestores a tomar rápidas decisões de fornecimento e compra, isto é o gerenciamento de materiais. Além disto os dados coletados podem detectar falhas ou sazonalidade nos processos, antes que os prejuízos econômicos, ambientais e sociais propaguem-se.

\footnotetext{
${ }^{4}$ Informação particular do gestor ambiental do SENAI
} 
Para o sistema de grande porte, no presente caso o SAP, a maior vantagem é a possibilidade de geração de relatórios instantaneamente e com uma interface visual gráfica de simples compreensão e veiculação pela web. Porém, um sistema formado com banco de dados também é eficaz, contudo a geração de indicadores de forma gráfica para os balanços, depende do uso de uma interface gráfica, e o cadastro de dados, apesar de provavelmente requerer mão de obra menos qualificada, é mais lento.

Os indicadores propostos para a implantação do conceito de Ecologia Industrial, se bem organizados graficamente, propõem uma forma de gestão com menor impacto ao ambiente e às futuras gerações, isto é sustentável. Os indicadores gerados também podem ser usados como ferramenta de conscientização para a promoção da educação ambiental. O uso do software pode alavancar novos negócios pela facilidade e agilidade no processamento de dados que apresenta, emitindo informações de forma clara e on line. Assim pode facilitar o comércio do e-waste, por exemplo, agilizando leilões virtuais. Hoje este processo de venda de co-produtos é controlado por anúncios na web e por banco de dados de empresas em uma espécie de banco de co-produtos, disponíveis em sites especializados. Este tipo de cadastro não é muito seguro pois as informações são disponíveis para qualquer pessoa e não há confiabilidade nem confidencialidade. Contudo, há tendência de melhoria no setor e no país já foi criada uma empresa de leilões virtuais usando o conceito de Ecologia Industrial (Mesa de Produção Mais Limpa 2004).

O uso de softwares ERP implica em alto custo, mas também é de alto custo o desenvolvimento completo da ACV. Por outro lado, um ACV simplificado pode ser obtido facilmente pelo uso de tais softwares. Assim, uma provável tendência é a utilização desses ACV simplificados para tomada de decisões, especialmente entre empresas, quanto à compra de produtos intermediários da produção. Outra provável tendência é o uso da tecnologia de identificação por raio freqüência (RFID), que hoje se encontra em fase de implantação e testes em diferentes empresas. Com o avanço desta técnica informações de destinação, localização e funcionamento podem ser enviadas por sinais de rádio a um servidor que atualizará os relatórios. Até o momento a RFID está sendo usada apenas para equipamentos montados, cada qual com seu código específico, no entanto pode-se esperar que em futuro próximo a codificação seja feita para cada 
componente do equipamento. Com isso a ACV simplificado poderia ser feita em qualquer fase do ciclo do equipamento e cada componente seria analisado.

Além disso, o uso de tais softwares parece indicar as vantagens da economia baseada no serviço. Estudiosos da evolução da produção defendem que em um mundo globalizado, onde todas as empresas têm acesso a uma tecnologia parecida, o diferencial na concorrência será o serviço e não mais o bem material. Todo o serviço que envolve o atendimento ao consumidor tende a englobar o bem material, assim empresas antevendo esta evolução começaram a montar a sua gestão na economia baseada na venda de serviços.

A economia baseada na venda de serviços, ao invés de venda de produtos, é proposta como um fator de vantagens ambientais e econômicas sob diversos aspectos. Implica em uma considerável mudança em toda a sociedade que, em grande escala, passaria a pagar pelos benefícios que obtém dos produtos, por exemplo com o seu aluguel, e não pelo produto em si. Lovins et al. (1999) apresentam o caso da Schindler, que estaria preferindo alugar sistemas de transporte vertical a vender elevadores. Considerando-se os empreendimentos como parte de um ecossistema industrial e empresas como fornecedores de co-produtos deve-se utilizar a lógica do fornecimento de serviços para permitir o fechamento de ciclos de produção, atingindo-se um estágio mais próximo da sustentabilidade, como fez por exemplo a Xerox, porém em ciclo interno.

Por fim, como a formação de ecossistemas industriais em geral promove uma melhora ambiental e econômica é útil o desenvolvimento de softwares mais simples, como proposto neste trabalho, para várias áreas produtivas. 


\section{. BIBLIOGRAFIA}

Agenda 21, Documento, Conferência Das Nações Unidas Sobre Meio Ambiente E Desenvolvimento, Rio De Janeiro, (1992). Disponível Em:

http://Www.Mma.Gov.Br/Estruturas/Agenda21

Anand, V., Data Warehouse Architecture For DDS Applications, Australian Journal Of Information System, (1996).

Ayres, R. U., Simonis, U. E., Industrial Metabolism: Restructuring For Sustainable Development - Tokyo, New York, United Nations University Press, (1994).

Azevedo, R. C.; Bremer, C. F.; Rebelatto, D. A. N., Et Al. Use Of Erp And Crm Support Demand Management In Make-To-Stock Production Environments., Gest. Prod., v.13, n.2, pag.179-190 (2006).

Ball, R. M., Re-Use Potential And Vacant Industrial Premises: Revisiting The Regeneration Issue In Stoke-On-Trent, Journal Of Property Research, v.19, n.2, pag.93110, (2002). Developers, Regeneration And Sustainability Issues In The Reuse Of Vacant Industrial Buildings, Rick Ball, Building Research \& Information, v.27, n.3, pag.140148, (1999).

Bebbington, J.; Gray, R.; Hibbith, C.; Kirk, E., Full Cost Accounting: An Agenda For Action, Certified Accountants, Ed. Trust, London, 174 Pages, (2001).

Bovo, V. G., Responsabilidade Social: Estudo De Caso Do Núcleo De Ação Comunitária Da Associação Franciscana De Ensino Senhor Bom Jesus, Universidade Federal De Santa Catarina Programa De Pós-Graduação Em Engenharia De Produção, Dissertação, 123 Pags., (2003).

Cavalcanti, M. S. A., Modelo De Avaliação Da Estratégia Ambiental: Uma Ferramenta Para A Tomada De Decisão, Doutorado, Florianópolis, Universidade Federal De Santa Catarina Programa De Pós-Graduação Em Engenharia De Produção, 218 Pags, (2001).

Cebds, (1997). Acessado Setembro/2006. Disponível Em : www.Cebds.org.br 
Chohfi , F. M.; Dupas, F. A. E.; Lora, E. S., Análise De Emissão E Seqüestro De $\mathrm{CO}_{2} \mathrm{Na}$ Geração De Eletricidade Excedente No Setor Sucro-Alcooleiro, $5^{\circ}$ Encontro De Energia No Meio Rural E Geração Distribuída, Agrener Gd 200419 - 21 De Outubro De 2004 Campinas, cd-rom.

Deodato, A.; Carneiro, M. T. P., Análise Das Estratégias Do Projeto Para Incorporação De Princípios E Indicadores De Sustentabilidade Em Políticas Públicas No Minicípio De Jaboticabal-S.P., Mestrado, UFSCAR, São Carlos, 229 Pags, (2005).

--- Environmental Best Practice Guide For Printed Circuit Board Industry, Green Chemistry, G53, (04/2000).

Felipe, D. L., Os Sistemas Integrados De Gestão (ISO9000, ISO14000, Ohsas18001) Como Indicadores De Responsabilidade Social (Sa8000) Em Processos Produtivos De Indústrias De Confecções No Espirito Santo, Universidade Federal De Santa Catarina Engenharia De Produção - Brasil, Florianópolis, 171 Pags, (2001).

Ferreira, G. E., A Competitividade Da Mineração De Ferro No Brasil, Mct. Cetem, 54 Pags, Issn 0103-6319, (2001).

Fragomeni, A. L. M., Parques Industriais Ecológicos Como Instrumento De Planejamento E Gestão Ambiental Cooperativa, Pós-Graduação Em Engenharia Da Universidade Federal Do Rio De Janeiro, 111 Pags., (2005).

Gameiro, J., Desenvolvimento De Tecnologias Mais Limpas Aplicadas À Microeletrônica, Escola Politécnica da Universidade de São Paulo, (2002).

Gameiro J. B., Ecossistemas Industriais, Notícias Fiesp/Ciesp, v.6, pág.15-17, (2002).

Gameiro, J., Silva, Maria Lúcia Pereira Da, Ecologia Industrial No Setor Eletroeletrônico. VIII Engema, Rio De Janeiro, cd-rom, (2005).

Gaspar H. Korndorfer, Lawrence E. Datnoff, Adubação Com Silício: Uma Alternativa No Controle De Doenças Da Cana-De-Açúcar E Do Arroz, Formações Agronomicas, v.70, pag.1-5, (1995). 
Giannetti, B. F. C. Almeida, M. V. B., Ecologia Industrial Conceitos, Ferramentas E Aplicações, Ed. Edgard Blucher, S. Paulo, (2006).

Global Reporting Initiative, Diretrizes Para O Relatório De Sustentabilidade, Versão 3, (2006). Acessado Setembro/2006. Disponível Em : www. Globalreporting.org

Harlan, A., Cooperating Latch And Handle For A Copier Subsystem, Us Patent, v.5, pag.819-139, (1998).

Hui, I. K.; Li, C. P.; Lau, H. C. W., Hierarchical Environmental Impact Evaluation Of A Process In Printed Circuit Board Manufacturing, International Journal Of Production Research, v.41, n.6, pag.1149-1165, (2003).

Hunkeler, D.; Rebitzer, G., The Future Of Life Cycle Assessment The International Journal Of Life Cycle Assessment, v.10, n.5, (2005).

Indicadores Da Fundação Vanzolini, Portal Do Meio Ambiente, Rebia - Rede Brasileira De Informação Ambiental, (2007). Acessado Em Janeiro/2007. Disponível Em: http:/Www.Jornaldomeioambiente.Com.Br/Gestaoambiental/Fundacaovanzolini.asp

Inmon, W., Building The Data Warehouse, Wiley Computer Publishing, New York, Third Edition. (2002).

ISE, Índice De Sustentabilidade Empresarial, Bovespa. Acessado Agosto/2006. http://Www.Bovespa.Com.Br/Pdf/Indices/Ise.Pdf

Jacobs Engineering Group Inc. Ed., Source Reduction And Recycling Of Halogenated Solvents In The Electronics Industry, Technical Support Document, The Metropolitan Water District And The Environmental Defense Fund, (1988).

Januschkowetz, A.; Hendrickson, C. T., Product And Process Life Cycle Inventories Using Sap $\mathrm{R} / 3$, Proceedings Of The 2001 IEEE International Symposium: Electronics And The Environment, pag.59-65, Denver, Co, Usa, (2001).

Lems, S.; Van Der Kooi, H. J.; De Swaan Arons, J.; Quantifying Technological Aspects Of Process Sustainability: A Thermodynamic Approach, Clean Technologies And Environmental Policy, v.5, n.3-4, pag.248-253, (2003). 
Lems, S.; Van Der Kooi, H. J.; De Swaan Arons, J.; Green Chem., The Sustainability Of Resource Utilization, Geo Cidade De São Paulo: Panorama Do Meio Ambiente Urbano / Svma, Ipt. - São Paulo : Prefeitura Do Município De São Paulo. Secretaria Municipal Do Verde E Do Meio Ambiente ; Brasília : Pnuma, v.4, pág.308-313, (2004).

Mattos, 1., A Importância Do Setor De Transportes Na Emissão De Gases Do Efeito Estufa - O Caso Do Município Do R.J., UFRJ, 222 Pags., (2001).

Mcdonnell, D. W.; Christie, M. A., Semiconductor Devices Drive Environmentally Conscious Product (ECP) Goals, Electronics And The Environment, IEEE-1999. Proceedings Of The 1999 IEEE International Symposium, Danvers, Ma, Usa, pag.7-12, (1999).

Minetti, B., Formação De Ecossistemas Industriais, Monografia, Fatec, (2005).

Nakayama, M., Present And Future Demand Of Silicon Metal, $2^{\text {nd }}$ International Workshop On Qits: Sustainability And The Ascent Of High Tech Silicon-Based Industries, The United Nations University, Institute Of Advanced Studies, Tokyo, (1998).

Oliveira, Nelson Brasil De, Fine Chemistry Innovation And Production. Quím. Nova, v.28, suppl.0, São Paulo, pag.s79-s85, (2005).

Oliveira, Nelson Brasil De, Cronologia Do Desenvolvimento Científico, Tecnológico E Industrial Brasileiro 1938-2003., Secretaria De Tecnologia Industrial, Capítulo Química Fina, (2004).

Pasqualini, A., Estudo De Caso Aplicado A Galvanoplastia., Engenharia De Produção, UFSC, (2004).

Pearce, A. R.; Vanegas, J. A.; Defining Sustainability For Built Environment Systems: An Operational Framework, International Journal Of Environmental Technology And Management, v.2, n.1-3, pag.94-113, (2002).

Pedersen, s.W., Electronics Industry Environmental Roadmap, Proceedings Of The 1995 IEEE International Symposium On Electronics And The Environment, Orlando, Fl, Usa Isbn: 0-7803-2137-5, pag.285-289, (05/1995). 
Peng, T. K., Electronics And The Environment - Singapore Perspective, Thesis, University Of Southern Queensland Faculty Of Engineering And Survey, 151 Pages, (2005).

Pinto, A. L.; Ribeiro, M. S., O Balanço Social Como Instrumento De Evidenciação De Responsabilidade Social: Um Estudo No Estado De Santa Catarina, $3^{\circ}$ Congresso Uso De Controladoria E Contabilidade, V.1-3, S. Paulo, (2003). Disponível Em : Http://Www.Eac.Fea.Usp.Br/Congressousp/Congresso3/Trabalhos/323.Pdf

Poudel, M. P., Assessment Of Sustainability Of Community Forestry Through Combined Analysis Of Field And Remotely Sensed Indicators (A Case Study In Siraha And Saptari Districts, Nepal), Master Of Science, International Institute For Geo-Information Science And Earth Observation Enschede, The Netherlands, (2002).

Prado M. Renato, Calcário E Escória De Siderurgia Avaliados Por Análise Foliar, Acúmulo E Exportação De Macronutrientes Em Cana-De-Açúcar, Scientia Agrícola, v.59, n.1, pag.129-135, (2002).

---, Proceedings Of The First Workshop On Qits: Materials Life-Cycle And Sustainable Development, Workshop Held In Campinas, Brazil, March 2-4, Ed Unu/Ias In Tokyo, 239 Pages, (1998).

Robinson, J. Squaring The Circle? Some Thoughts On The Idea Of Sustainable Development. Ecological, Economics, v.48, pág.369-384, (2004).

Roselino, J. E.; Gomes, R, Limites E Possibilidades Do Brasil Nas Configurações Produtivas Globalizadas. Software E As Cadeias Produtivas Internacionalizadas, Relatório Final De Pesquisa, Araraquara / Campinas, (2000). Disponível Em: http://Geein.Fclar.Unesp.Br/Atividades/lpea/Arquivos/Software.Pdf

Rossi M. S.; Szejnwald, H. B.; Leo, W., Editorial Leaders In Sustainable Development: How Agents Of Change Define The Agenda Baas Business Strategy And The Environment, v.9, pag.273-286, (2000).

Sage, J., Waste Minimization And Its Ecological Evaluation. A Case Study In Printed Circuit Board Manufacture, Fuel And Energy Abstracts, v.36, n.6, pag.468, (1995). 
Santillo, D., Labunska, I., Brigden, K., Background Documents On Three Key Elements Of The Electronics Manufacturing Sector: Semiconductors, Printed Wiring (Circuit) Boards And TFT-LCD Screens Adam Walters, Greenpeace Research Laboratories Technical Note 08/2006, Grl-Tn-08-2006, 34 Pages, (2006).

Sérgio, M., Regras Ambientais Afetam O Comércio Exterior, Revista Abinee, pág.3, (2005).

Simondon, G.; Andrade, T., Intersecções Entre O Ambiente E A Realidade Técnica: Contribuições Do Pensamento De ..., Ambient. Soc., n.8, Campinas, (2001).

Silva, Eduardo Ramos Ferreira Da; Silva, Maria Lúcia Pereira Da, Waste Minimization On PCB Board Industries: Importance Of The Audit Process. I Workshop On Quartz International Trade System, Campinas, pag.154-158, (1998).

Silva, Ecologia Industrial : O Que É, Para Que Serve E Quanto Custa?, Revista Ipesi, pág.18-20 (2004).

Sodhi, M. S.; Reimer, B., Models For Recycling Electronics End-Of-Life Products, Or Spectrum, v.23, n.1, pag.97-115, (2001).

Souza, P. A., A Dimensão Ambiental No Planejamento Da Mineração - Um Enfoque Empresarial, Bahia Análise \& Dados Salvador - Ba Sei, v.10, n.4, pág.280-305, (2001).

Stanley, E. Manahan, Industrial Ecology: Environmental Chemistry And Hazardous Waste - Boca Raton, Fla.: Lewis Publishers, (1999).

Stobbe, I.; Middendorf, A.; Schischke, K.; Petermann1, C.; Griese, H.; Müller, J.; Reichl, H., Meeting Data Requirements By Using The Izm/Ee-Toolbox For A Screening Assessment Of The Environmental Impacts Of Electronic Products, European Conference On Electronics And The Environments, Greenpack-Project, Oslo/N, pag.1213, (2001).

Suzuki, C. K.; Pereira, J. T. V., Energia Solar E Produção De Silício Metálico Baseado No Programa Qits ("Quartz Industrial Trade System"). In: Encontro De Energia No Meio 
Rural, 3., Campinas, (2000). Anais Eletrônicos... Acesso Em: 17 Jan. 2007. Disponível Em:

http://Www.Proceedings.Scielo.Br/Scielo.Php?Script=Sci_Arttext\&Pid=Msc0000000022 000000100009\&Lng=Pt\&Nrm=Abn

Unep/Sustainability.Company Environmental Reporting, A Measure Of The Progress Of Business And Industry Towards Sustainable Development. Paris: Unep/Sustainability. Tecnical Report N. 24, (1992).

UNEP, Environmental Data Report, Second Edition 1988/89. United Nations Environment Programme. Blackwell Publishers, Oxford, (1989). Disponivel Em : http://Www.Uneptie.Org/Pc/Cp/Understanding_Cp/Home.Htm\#Definition

United Nations Environment Programme: Industry And Environment, Technical Report No. 24, Company Environmental Reporting - A Measure Of The Progress Of Business And Industry Towards Sustainable Development, Usa, (1992).

Video, Desenvolvimento Susténtável, 20 Minutos, Cebds, (2001).

Williams, Industrial Trade Systems And Life Cycle Assessment, Advanced Perspectives, n.3, pag.6-7, (1999).

World Commission On Environment And Development, Our Common Future, New York: Oxford University Press, pag.43, (1987).

Yilmaz, Ö., Hazardous Waste Inventory Of Turkey, Thesis, The Graduate School Of Natural And Applied Sciences Of Middle East Technical University, 285 Pages, (2006).

Young, T.; Rigby, D.; Woodhouse, P.; Burton, M., Constructing A Farm Level Indicator Of Sustainable Agricultural Practice, Ecological Economics, v.39, pag.463-478, (2001).

Young, J. W. S., A Framework For The Ultimate Environmental Index - Putting Atmospheric Change Into Context With Sustainability, Environmental Monitoring And Assessment, Earth And Environmental Science, v.46, n.1-2, pag.135-149, (1997). 
Young, D.; Scharp, R.; Cabezas, H.; The Waste Reduction (War) Algorithm: Environmental Impacts, Energy Consumption, And Engineering Economics, Waste Management, v.20, pag.605-615, (2002).

Zandersons, J.; Kokorevics, A.; Gravitis, J., Studies Of Bagasse Charcoal Briquetting, Reduction Of The Ash Content In Charcoal, And Preliminary Material And Energy Estimations For The Design Of A Pilot Plant Of Bagasse Charcoal, Unu/Ias Working Paper, n.58, pag.1-33, (1999).

Zandersons, J.; Kokorevics, A.; Gravitis, J.; Kallavus, U.; Suzuki, C. K., Studies Of The Modified Bagasse Plastics Carbonisation And A Feasibility To Produce Carbon Construction Materials, Unu/Ias Working Paper, n.75, pag.1-54, (2000).

Zuffo, J. A., A Sociedade E A Economia No Novo Milenio: Os Empregos E As Empresas No Turbulento Alvorecer No Seculo XXI, Livro 1: A Tecnologia E A Infossociedade. Barueri: Manoel, (2003).

Zuffo, J. A., A Sociedade E A Economia No Novo Milenio: Os Empregos E As Empresas No Turbulento Alvorecer No Seculo XXi, Livro 2. Barueri: Manoel, (2004).

Zuffo, J. A., A Sociedade E A Economia No Novo Milenio: Os Empregos E As Empresas No Turbulento Alvorecer No Seculo XXi, Livro 3. Barueri: Manoel, (2005). 


\section{ANEXO 1}

\section{INDICADORES DE SUSTENTABILIDADE E CORRELAÇÃO COM O SOFTWARE DE ERP}

\begin{tabular}{|c|c|c|c|c|}
\hline Indicador & Característica & Objetivo & $\begin{array}{l}\text { Funcionalidade } \\
\text { do sistema de } \\
\text { ERP utilizada }\end{array}$ & $\begin{array}{c}\text { Dimensão da } \\
\text { sustentabilidade }\end{array}$ \\
\hline $\begin{array}{l}\text { Relatórios } \\
\text { Balanço Social }\end{array}$ & $\begin{array}{l}\text { Comprometimento } \\
\text { com o } \\
\text { Desenvolvimento } \\
\text { Social; } \\
\text { Análise Histórica }\end{array}$ & $\begin{array}{l}\text { Divulgação, } \\
\text { Orientação, } \\
\text { Valores; } \\
\text { Credibilidade } \\
\text { nos Critérios e } \\
\text { Metas }\end{array}$ & $\begin{array}{l}\text { Relatórios do } \\
\text { Human Resources }\end{array}$ & \multirow[t]{7}{*}{ Compromisso } \\
\hline $\begin{array}{l}\text { Investimento } \\
\text { em } \\
\text { Fornecedores } \\
\text { Específicos }\end{array}$ & $\begin{array}{l}\text { Compromissos } \\
\text { Voluntários }\end{array}$ & $\begin{array}{l}\text { Avaliação, } \\
\text { Controle }\end{array}$ & $\begin{array}{l}\text { Dado Mestre de } \\
\text { Fornecedores }\end{array}$ & \\
\hline $\begin{array}{l}\text { Comitê de } \\
\text { Sutentabilidade }\end{array}$ & Organograma & $\begin{array}{l}\text { Estrutura } \\
\text { Hierárquica e } \\
\text { Organizacional } \\
\text { claras }\end{array}$ & $\begin{array}{l}\text { Relatório do } \\
\text { Human Resources }\end{array}$ & \\
\hline $\begin{array}{l}\text { Divulgação } \\
\text { interna do } \\
\text { Balanço Social }\end{array}$ & Análise Setorial & Metas, incentivo & Balance Scorecard & \\
\hline Pagamentos & $\begin{array}{l}\text { Participação nos } \\
\text { Lucros e Resultados }\end{array}$ & $\begin{array}{l}\text { Valores, } \\
\text { incentivo }\end{array}$ & $\begin{array}{l}\text { Relatório de } \\
\text { Financial } \\
\text { Accounting }\end{array}$ & \\
\hline Contingência & Controle de Dados & Confiabilidade & & \\
\hline $\begin{array}{l}\text { Pesquisa } \\
\text { Mercadológica }\end{array}$ & Marketing & $\begin{array}{l}\text { Apelo e } \\
\text { conscientização }\end{array}$ & $\begin{array}{l}\text { Customer } \\
\text { Relationship } \\
\text { Management }\end{array}$ & \\
\hline
\end{tabular}




\begin{tabular}{|l|l|l|l|l|}
\hline ISO & $\begin{array}{l}\text { Toxidade de } \\
\text { Produtos }\end{array}$ & Controle & $\begin{array}{l}\text { Dado mestre de } \\
\text { materiais }\end{array}$ & \\
\hline
\end{tabular}

Para a visão de compromisso, o sistema de ERP oferece 87,5\% dos indicadores nos dados mestres de material, fornecedor, no CRM (Customer Relationship Management), nos relatórios de financeiros e de recursos humanos, além do BSC para divulgação interna. Para exemplificar: cadastrando-se o fornecedor com um tipo específico, podem-se colocar restrições, considerando a origem ou distância. Nos dados mestres de materiais a toxidade do produto é informada no momento de recebimento, com restrições pré-estipuladas.

\begin{tabular}{|c|c|c|c|c|}
\hline Indicador & Característica & Objetivo & $\begin{array}{l}\text { Funcionalidade } \\
\text { do sistema de } \\
\text { ERP utilizada }\end{array}$ & Dimensão \\
\hline Consumo & $\begin{array}{l}\text { Política de } \\
\text { Redução de } \\
\text { tóxicos e } \\
\text { ecoeficiência }\end{array}$ & Desmaterialização & $\begin{array}{l}\text { Dado mestre de } \\
\text { material } \\
\text { (Histórico de } \\
\text { consumo) }\end{array}$ & \multirow[t]{4}{*}{$\begin{array}{l}\text { Natureza do } \\
\text { Produto }\end{array}$} \\
\hline $\begin{array}{l}\text { Balanço de } \\
\text { massa }\end{array}$ & Emissões & $\begin{array}{l}\text { Redução e } \\
\text { Controle }\end{array}$ & $\begin{array}{l}\text { Relatórios de } \\
\text { Production } \\
\text { process }\end{array}$ & \\
\hline $\begin{array}{l}\text { Quantidade de } \\
\text { processos }\end{array}$ & Ações Judiciais & $\begin{array}{l}\text { Atendimento a } \\
\text { auditorias }\end{array}$ & & \\
\hline $\begin{array}{l}\text { Relatório de } \\
\text { ciclo de vida }\end{array}$ & ACV & $\begin{array}{l}\text { Acompanhamento } \\
\text { e comparação }\end{array}$ & $\begin{array}{l}\text { Dado mestre de } \\
\text { materiais }\end{array}$ & \\
\hline
\end{tabular}

Para a natureza do produto o sistema possui $75 \%$ dos indicadores propostos pelas fontes pesquisadas, com o dado mestre de materiais para analisar historicamente a movimentação de um insumo e para disponibilizar dados para o ACV conforme demonstrado por Hendrikson (2001), para o balanço de massa o módulo de PP (Production Process) possui relatórios de emissão. 


\begin{tabular}{|c|c|c|c|c|}
\hline Indicador & Característica & Objetivo & $\begin{array}{l}\text { Funcionalidade } \\
\text { do sistema de } \\
\text { ERP utilizada }\end{array}$ & Dimensão \\
\hline $\begin{array}{l}\text { Diversividade } \\
\text { de capital e } \\
\text { Marketshare }\end{array}$ & $\begin{array}{l}\text { Acionistas } \\
\text { satisfeitos }\end{array}$ & Ações Sociais & & Governança \\
\hline $\begin{array}{l}\text { Pagamentos } \\
\text { Multas }\end{array}$ & $\begin{array}{l}\text { Sanções legais e } \\
\text { Processos } \\
\text { Judiciais }\end{array}$ & Controle & & \\
\hline $\begin{array}{l}\text { Automação } \\
\text { e MRP }\end{array}$ & $\begin{array}{l}\text { Administração de } \\
\text { estoque }\end{array}$ & $\begin{array}{l}\text { Controle de } \\
\text { demanda }\end{array}$ & MRP & \\
\hline $\begin{array}{l}\text { Conselho de } \\
\text { Administrativo } \\
\text { (existência) }\end{array}$ & Organograma & $\begin{array}{l}\text { Participação } \\
\text { igualitária/ } \\
\text { Transparência }\end{array}$ & $\begin{array}{l}\text { Módulo de } \\
\text { Human } \\
\text { resources }\end{array}$ & \\
\hline Relatórios & $\begin{array}{l}\text { Prestação de } \\
\text { Contas }\end{array}$ & $\begin{array}{l}\text { Atendimento a } \\
\text { Auditoria }\end{array}$ & $\begin{array}{l}\text { Balance } \\
\text { Scorecard }\end{array}$ & \\
\hline Código & Conduta & Ética & & \\
\hline Avaliação $360^{\circ}$ & Qualidade Gestão & Avaliação & & \\
\hline
\end{tabular}


Para a governança o software disponibiliza $50 \%$ dos indicadores requeridos no balanço de sustentabilidade, com o Material Resource Planning para controlar a compra de insumos e fazer a gestão de demanda com base no histórico, com a consolidação de dados no BSC para atendimento ágil a auditorias e com a disponibilização do organograma para comprovar a existência de um conselho administrativo.

\begin{tabular}{|l|l|l|l|l|}
\hline Indicador & Característica & Objetivo & $\begin{array}{l}\text { Funcionalidade } \\
\text { do sistema de } \\
\text { ERP utilizada }\end{array}$ & Dimensão \\
\hline $\begin{array}{l}\text { Conselho de } \\
\text { Diretoria } \\
\text { (existência) }\end{array}$ & $\begin{array}{l}\text { Organograma/Definição } \\
\text { de valores }\end{array}$ & $\begin{array}{l}\text { Avaliação da } \\
\text { Gestão }\end{array}$ & $\begin{array}{l}\text { Human } \\
\text { Resources }\end{array}$ & $\begin{array}{l}\text { Econômico } \\
\text { Financeira }\end{array}$ \\
\cline { 1 - 4 } $\begin{array}{l}\text { Base de Dados } \\
\text { Configuração }\end{array}$ & $\begin{array}{l}\text { Política de Controle de } \\
\text { Ativos Intangíveis }\end{array}$ & $\begin{array}{l}\text { Controle e } \\
\text { documentação }\end{array}$ & $\begin{array}{l}\text { Knowledge } \\
\text { Management }\end{array}$ & \\
\hline Produtividade & $\begin{array}{l}\text { Gestão do } \\
\text { Desempenho }\end{array}$ & $\begin{array}{l}\text { Definição de } \\
\text { Metas }\end{array}$ & $\begin{array}{l}\text { Production } \\
\text { Planning }\end{array}$ & \\
\cline { 1 - 3 } $\begin{array}{l}\text { Monitoramentos } \\
\text { Impactos não } \\
\text { diretos }\end{array}$ & $\begin{array}{l}\text { Gestão da } \\
\text { Sustentabilidade }\end{array}$ & $\begin{array}{l}\text { Controle das } \\
\text { Metas }\end{array}$ & & \\
\hline
\end{tabular}




\begin{tabular}{|l|l|l|l|}
\hline $\begin{array}{l}\text { Relatórios de } \\
\text { balanço } \\
\text { financeiro }\end{array}$ & Divulgação & Transparência & $\begin{array}{l}\text { Financial } \\
\text { Accounting }\end{array}$ \\
\hline $\begin{array}{l}\text { Gerenciamento } \\
\text { do } \\
\text { Fornecimento }\end{array}$ & $\begin{array}{l}\text { Otimização das } \\
\text { compras }\end{array}$ & $\begin{array}{l}\text { Redução de } \\
\text { custos }\end{array}$ & $\begin{array}{l}\text { Vendor } \\
\text { Relationship } \\
\text { Management }\end{array}$ \\
\hline $\begin{array}{l}\text { Pagamentos } \\
\text { de multas }\end{array}$ & $\begin{array}{l}\text { Atendimento a } \\
\text { Legislação }\end{array}$ & $\begin{array}{l}\text { Conscientização } \\
\text { e Prevenção }\end{array}$ & \\
\hline Testes & $\begin{array}{l}\text { Gestão de } \\
\text { Disponibilidade }\end{array}$ & $\begin{array}{l}\text { Controle de } \\
\text { Qualidade }\end{array}$ & $\begin{array}{l}\text { Quality } \\
\text { Management }\end{array}$ \\
\hline
\end{tabular}

Na dimensão Econômico Financeira, o sistema de ERP estudado cobre $71 \%$ dos indicadores propostos com os módulos de Knowledge Management para gerenciar documentações, Production Planing para o controle da produtividade, Quality Management e Financial Accounting para fornecer relatórios e estabelecer restrições de pagamentos por datas e recebimento de materiais por testes de qualidade.

\begin{tabular}{|l|l|l|l|l|}
\hline Indicador & Característica & Objetivo & $\begin{array}{l}\text { Funcionalidade } \\
\text { do sistema de } \\
\text { ERP }\end{array}$ & Dimensão \\
\hline $\begin{array}{l}\text { Gestor } \\
\text { Ambiental } \\
\text { (existência) }\end{array}$ & Organograma & $\begin{array}{l}\text { Gerenciamento } \\
\text { de impacto dos } \\
\text { processos }\end{array}$ & $\begin{array}{l}\text { Relatórios do } \\
\text { Human } \\
\text { Resources }\end{array}$ & $\begin{array}{l}\text { Política } \\
\text { ambiental }\end{array}$ \\
\cline { 1 - 3 } $\begin{array}{l}\text { Contrato de } \\
\text { seguro }\end{array}$ & $\begin{array}{l}\text { Seguro contra } \\
\text { degradação } \\
\text { ambiental }\end{array}$ & Segurança & $\begin{array}{l}\text { Relatórios de } \\
\text { documentos de } \\
\text { compra }\end{array}$ & \\
\hline
\end{tabular}




\begin{tabular}{|l|l|l|l|}
\hline $\begin{array}{l}\text { Ativos } \\
\text { Ambientais }\end{array}$ & $\begin{array}{l}\text { Áreas de } \\
\text { preservação }\end{array}$ & Reserva legal & $\begin{array}{l}\text { Relatórios dos } \\
\text { Ativos fixos }\end{array}$ \\
\hline $\begin{array}{l}\text { Consumo de } \\
\text { insumos tóxicos }\end{array}$ & $\begin{array}{l}\text { Metodologia de } \\
\text { 3R's e de Produção } \\
\text { Mais Limpa }\end{array}$ & $\begin{array}{l}\text { Redução de } \\
\text { Impacto }\end{array}$ & $\begin{array}{l}\text { Dados mestres } \\
\text { de material }\end{array}$ \\
\hline Certificações & $\begin{array}{l}\text { Gestão Saúde de } \\
\text { Segurança } \\
\text { Ocupacional }\end{array}$ & $\begin{array}{l}\text { Redução de } \\
\text { Acidentes }\end{array}$ & \\
\hline $\begin{array}{l}\text { Divulgação } \\
\text { Treinamento }\end{array}$ & Gestão de Riscos & $\begin{array}{l}\text { Redução de } \\
\text { não } \\
\text { conformidades }\end{array}$ & $\begin{array}{l}\text { Relatórios do } \\
\text { Resources }\end{array}$ \\
\hline P\&D & Tecnologias Limpas & $\begin{array}{l}\text { Produtos } \\
\text { Verdes }\end{array}$ & \\
\hline $\begin{array}{l}\text { Cadastro } \\
\text { de áreas de } \\
\text { risco }\end{array}$ & Rastreabilidade & Controle & \\
\hline
\end{tabular}

A dimensão política ambiental tem $62,5 \%$ de seus indicadores cobertos pelo software.

\section{ANEXO 2 INDICADORES PARA O PROGRAMA SEATTLE SUSTENTÁVEL}

\section{Meio ambiente:}

- Volta dos salmões para desova nos rios da Comarca de King (indicador da qualidade da água, saúde ambiental e biodiversidade como um todo: em queda vertiginosa)

- Saúde de áreas inundadas (medida pela qualidade da água, flutuação do nível da água e saúde dos anfíbios: todos em queda)

- Biodiversidade (medida pela diversidade de anfíbios e plantas nos banhados da Comarca de King: em queda)

- Erosão do solo (medida pela turbidez dos cursos de água na Comarca de King: em ascensão)

- Porcentagem das ruas de Seattle que atingem critérios de 'atenção ao pedestre' (indicador da qualidade do meio ambiente urbano: dados insuficientes para determinar a tendência) 
- Superfície impermeabilizada na cidade de Seattle (relacionada ao escorrimento da água de superfície e problemas de qualidade da água: dados insuficientes para determinar a tendência)

- Qualidade do ar (medida de acordo com as Normas da EPA para Poluentes: em alta desde 1980)

- Áreas abertas (levantamentos das áreas acessíveis em comparação com as metas do planejamento urbano; os níveis atuais estão abaixo dos níveis desejados, e não há dados suficientes para determinar a tendência)

\section{População e Recursos:}

- Taxa de crescimento populacional (em queda do atual nível de $0,8 \%$ )

- Consumo residencial de água (per capita está em queda, geral ainda em alta)

- Geração e reciclagem de resíduos sólidos (a geração per capita continua em alta, mas a reciclagem per capita está aumentando em ritmo mais acelerado)

- Prevenção da poluição e uso de recursos renováveis (a emissão de tóxicos medida pelo Inventário de Emissões Tóxicas da EPA está em baixa; o uso de produtos de papel reciclado está em alta)

- Área agrícola na Comarca de King (em baixa)

- Quilometragem e consumo de combustível por veículo (estável, após vinte anos de alta constante

- Uso de energia renovável e não-renovável (medida da sustentabilidade energética a longo prazo: dependência da energia não-renovável em alta)

\section{Economia:}

- Porcentagem de emprego concentrado nos dez maiores empregadores (indicador negativo da diversidade e flexibilidade econômica; em baixa)

- Desemprego real (atualmente em baixa, seguindo os ciclos comerciais tradicionais, mas os empregos estão distribuídos desigualmente)

- Distribuição da renda pessoal (indicador da equidade econômica; distância entre ricos e pobres está aumentando, e a classe média está perdendo terreno)

- Despesas com assistência médica (selecionado por causa de sua visível urgência e impacto potencial sobre a viabilidade econômica: em alta rápida) 
- Horas de trabalho pelo salário médio da Comarca de King necessárias para atender as necessidades mais básicas de vida (medida do poder aquisitivo: sem alterações desde 1982)

- Recursos para habitação (em alta para quem compra a casa própria; em baixa para os inquilinos de baixa renda)

- Crianças vivendo na pobreza (indicador negativo da saúde social e equidade social: em alta)

- Uso de sala de emergência para outros fins (indicador negativo do acesso à assistência médica: em alta)

- Capital comunitário (recursos disponíveis para o desenvolvimento econômico local, medido pelos depósitos em bancos locais: em queda)

\section{Juventude e Educação:}

- Adultos alfabetizados (indicador de capacidade intelectual social; dados históricos insuficientes para determinar tendência)

- Conclusão do segundo grau (medida básica do sucesso educacional; dados insuficientes para determinar tendências a longo prazo)

- Diversidade étnica dos professores (medida de equidade: atualmente equivalente à diversidade da população adulta, mas não da dos alunos, e dados insuficientes para determinar tendências a longo prazo)

- Educação artística (medida do investimento educacional no raciocínio criativo: não há disponibilidade de dados)

- Envolvimento voluntário nas escolas (medida do investimento da comunidade no bem estar da próxima geração: dados insuficientes para determinar tendências)

- Delinqüência juvenil (indicador negativo da segurança pública atual e futura: em alta)

- Jovens envolvidos em serviços comunitários (indicador positivo da cidadania atual e futura: não há disponibilidade de dados)

\section{Saúde e Comunidade:}

- Eqüidade na justiça (indicador básico de eqüidade, medido pelas diferenças no tratamento judicial de delinqüentes juvenis de diferentes etnias: dados insuficientes para determinar uma tendência, mas existem marcantes desigualdades) 
- Recém-nascidos de baixo peso (importante indicador negativo de futuros problemas sociais: finalmente estabilizado, depois de anos em alta, principalmente entre grupos menos favorecidos)

- Taxa de hospitalização infantil por asma (indicador relacionado à pobreza e qualidade ambiental local: em alta rápida)

- Participação dos eleitores nas eleições primárias (indicador da cidadania comunitária: atualmente em alta, após anos de declínio)

- Utilização da biblioteca e centro comunitário (indicador positivo do desenvolvimento comunitário saudável: em alta)

- Participação pública nas artes (medida da vitalidade cultural: os níveis são elevados, mas os dados são insuficientes para determinar tendências)

- Atividade de jardinagem (medida da ligação entre as pessoas e o meio ambiente: os níveis são elevados, mas os dados são insuficientes para determinar tendências)

- Boa vizinhança (medida da vitalidade e flexibilidade da comunidade, medida por levantamentos de relatos de interações com vizinhos: os níveis são elevados, mas os dados são insuficientes para determinar tendências)

- Qualidade de vida perceptível (medida da felicidade pessoal, avaliada por levantamentos da sensação individual de bem-estar das pessoas: os níveis são elevados, mas os entrevistados esperam que permaneçam elevados ou até melhorem).

\section{Bibliografia}

Adeodato, M. T. P. Carneiro, Análise das estratégias do projeto para incorporação de princípios e indicadores de sustentabilidade em políticas públicas no minicípio de Jaboticabal-SP, Mestrado, UFSCar, São Carlos, 2005, 229 p.

Sustainable Seattle, 1993. Indicators of Sustainable Community 1995. Metrocenter YMCA

\section{ANEXO 3 O CONCEITO DE PEQUENAS E MÉDIAS EMPRESAS}

O conceito de pequena e média empresa é muito controvertido, devido à grande variedade de indicadores a respeito. Para LONGENECKER et al (1998), existem alguns exemplos de critérios para a definição do tamanho da empresa, como número de 
empregados, volume de vendas, valor dos ativos, seguro da força de trabalho e volume de depósitos. Contudo, estes critérios variam, dependendo do autor ou situação, porque enquanto alguns critérios são aplicáveis a todas as áreas industriais, outros são relevantes apenas para certos tipos de negócio.

No Brasil, o critério ainda mais usado é o de número de empregados. Assim, pode ser classificada como pequena empresa aquela com o número de empregados geralmente menor que 100 e como média empresa aquela com o número de empregados entre 100 e 499. O SEBRAE utiliza a classificação de empresas pelo número de funcionários, e a Tabela A.3.1, construída a partir de informações coletadas junto ao SEBRAE/PR, demonstra de que forma este órgão define o porte das empresas.

Tabela A.3.1 - Classificação das Empresas Fonte: SEBRAE (2002)

\begin{tabular}{|l|l|l|l|}
\hline \multicolumn{1}{|c|}{ PORTE/SETOR } & \multicolumn{1}{|c|}{ INDÚSTRIA } & \multicolumn{1}{c|}{ COMÉRCIO } & \multicolumn{1}{c|}{ SERVIÇOS } \\
\hline Microempresa & Até 19 empregados & Até 9 empregados & Até 9 empregados \\
\hline Pequena Empresa & De 20 a 99 & De 10 a 49 & De 10 a 49 \\
\hline Média Empresa & De 100 a 499 & De 50 a 99 & De 50 a 99 \\
\hline Grande Empresa & Acima de 500 & Acima de 100 & Acima de 100 \\
\hline
\end{tabular}

Podem ser realizadas diversas combinações entre critérios quantitativos, como tentativa de minimizar a unidimensionalidade que cada critério proporciona. É o caso do que estabeleceu, a partir de 1993, a Comissão de Micro, Pequenas e Médias Empresas do MERCOSUL (GONÇALVES E KOPROWKSI, 1995). Esta Comissão definiu uma 
classificação para os países integrantes do MERCOSUL, conforme configurado na Tabela A.3.2.

Tabela A.3.2 - Classificação das Empresas por tamanho (MERCOSUL)

\begin{tabular}{|l|l|l|}
\hline CATEGORIA & Número de Empregados & Faturamento Anual \\
\hline Microempresa & Até 20 empregados & Até US\$ 400.000 \\
\hline Pequena Empresa & Até 100 empregados & Até US\$2.000.000 \\
\hline Média Empresa & Até 300 empregados & Até US\$ 10.000 .000 \\
\hline
\end{tabular}

\section{ANEXO 4 USO DE SOFTWARE ERP'S PELAS EMPRESAS}

Roselino (2000) avaliou o uso de software nas cadeias produtivas brasileiras. A análise das receitas das empresas de software em função do tamanho da empresa atendida é um dos dados fornecidos e é adaptado nas tabelas A.4.1 a A.4.3. É possível observar que empresas grandes usam preferencialmente o software SAP, mas para médias e pequenas Datasul e Microsiga, respectivamente, são os mais usados. Porém, o valor percentual do item "outros" cresce em relação à empresa líder. Este item normalmente corresponde a software desenvolvido pela própria empresa para controle de seus processos. Vale salientar que neste trabalho o tamanho da empresa foi definido a partir de seu faturamento.

TABELA A.4.1 Maiores receitas no segmento de ERP obtidas com grandes empresas como clientes. Ano de 1998 (ROSELINO, 2000) 


\begin{tabular}{|l|r|r|r|r|}
\hline \multicolumn{1}{|c|}{ Empresa } & $\begin{array}{r}\text { Receitas no segmento } \\
\text { (US\$ 000) }\end{array}$ & $\begin{array}{r}\text { Participação } \\
(\%)\end{array}$ & $\begin{array}{c}\text { Informática } \\
(\text { US\$ 000) }\end{array}$ & $\begin{array}{c}\text { Totais } \\
\text { (US\$ 000) }\end{array}$ \\
\hline SAP (SP) * & 81.927 & $55.0 \%$ & 143.000 & 143.000 \\
\hline Baan Brasil (SP) & 15.009 & $10.3 \%$ & 32.700 & 32.700 \\
\hline Consist (SP) & 13.800 & $9.4 \%$ & 115.000 & 115.000 \\
\hline Oracle Brasil (SP) & 7.672 & $5.2 \%$ & 137.000 & 137.000 \\
\hline Datasul (SC) & 2.049 & $1.4 \%$ & 74.500 & 74.500 \\
\hline Computer Associates (SP) & 3.666 & $2.5 \%$ & 141.000 & 141.000 \\
\hline System Software (SP) & 5.000 & $3.4 \%$ & 22.700 & 22.700 \\
\hline J. D. Edwards (SP) & 4.758 & $3.3 \%$ & 16.400 & 16.400 \\
\hline PeopleSoft (SP) & 1.701 & $1.2 \%$ & 8.100 & 8.100 \\
\hline Software (SP) & 631 & $0.4 \%$ & 9.700 & 9.700 \\
\hline Outros & 10.773 & $7.9 \%$ & & \\
\hline TOTAL & 146.355 & $100.0 \%$ & & \\
\hline
\end{tabular}

TABELA A.4.2 Maiores receitas no segmento de ERP obtidas com empresas médias como clientes. Ano de 1998 (ROSELINO, 2000) 


\begin{tabular}{|l|r|r|r|r|}
\hline \multicolumn{1}{|c|}{ Empresa } & $\begin{array}{c}\text { Receitas no segmento } \\
\text { (US\$ 000) }\end{array}$ & Share (\%) & $\begin{array}{c}\text { Informática } \\
(\text { US\$ 000) }\end{array}$ & $\begin{array}{c}\text { Totais } \\
(\text { US\$ 000) }\end{array}$ \\
\hline Datasul (SC) & 34.829 & $28.6 \%$ & 74.500 & 74.500 \\
\hline Microsiga (SP) & 11.560 & $9.5 \%$ & 51.376 & 51.376 \\
\hline Consist (SP) & 10.350 & $8.5 \%$ & 115.000 & 115.000 \\
\hline Sispro (RS) & 9.730 & $7.0 \%$ & 13.900 & 13.900 \\
\hline SAP (SP) $*$ & 8.367 & $6.9 \%$ & 143.000 & 143.000 \\
\hline J. D. Edwards (SP) & 7.442 & $6.1 \%$ & 16.400 & 16.400 \\
\hline Logocenter (SC) & 6.661 & $5.5 \%$ & 15.860 & 15.860 \\
\hline System Software (SP) & 6.500 & $5.3 \%$ & 22.700 & 22.700 \\
\hline Interquadram (RS) & 6.098 & $5.0 \%$ & 12.100 & 12.100 \\
\hline IFS (SP) & 4.532 & $3.7 \%$ & 10.300 & 10.300 \\
\hline Outros & 15.609 & $12.8 \%$ & & \\
\hline TOTAL & 121.678 & $100.0 \%$ & & \\
\hline
\end{tabular}

TABELA A.4.3 Maiores receitas no segmento de ERP obtidas com pequenas empresas como clientes. Ano de 1998 (ROSELINO, 2000)

\begin{tabular}{|l|r|r|r|r|}
\hline \multicolumn{1}{|c|}{ Empresa } & $\begin{array}{r}\text { Receitas no segmento } \\
\text { (US\$ 000) }\end{array}$ & Share (\%) & $\begin{array}{r}\text { Informática } \\
\text { (US\$ 000) }\end{array}$ & $\begin{array}{r}\text { Totais } \\
\text { (US\$ 000) }\end{array}$ \\
\hline Microsiga (SP) & 26.972 & $42.7 \%$ & 51.376 & 51.376 \\
\hline Audit (SC) & 7.725 & $12.2 \%$ & 10.300 & 10.300 \\
\hline Datasul (SC) & 4.098 & $6.5 \%$ & 74.500 & 74.500 \\
\hline R2V2 (SC) & 3.744 & $5.9 \%$ & 6.000 & 6.000 \\
\hline RM Sistemas (MG) & 2.769 & $4.4 \%$ & 21.300 & 21.300 \\
\hline Nasajon (RJ) & 2.020 & $3.2 \%$ & 3.700 & 3.700 \\
\hline Star Soft (SP) & 1.978 & $3.1 \%$ & 11.357 & 11.357 \\
\hline Interquadram (RS) & 1.143 & $1.8 \%$ & 12.100 & 12.100 \\
\hline Logocenter (SC) & 952 & $1.5 \%$ & 15.860 & 15.860 \\
\hline ABC71 (SP) $*$ & 459 & $0.7 \%$ & 6.702 & 6.702 \\
\hline Outros & 11.328 & $17.9 \%$ & & \\
\hline TOTAL & 63.188 & $100.0 \%$ & & \\
\hline
\end{tabular}

\section{ANEXO 5 A FORMAÇÃO DO BSC}

O primeiro passo para a formação do BSC é a definição dos dados do sistema que serão extraídos de acordo com os indicadores selecionados. A Figura A.5.1 mostra uma tela típica do software e possíveis indicadores selecionados. Após a seleção dos dados, os níveis dos indicadores são configurados, de acordo com as metas estipuladas, como 
mostra a tela de software da Figura A.5.2. Com os indicadores e as metas configuradas o sistema extrai os indicadores dos dados mestres do sistema, por exemplo, materiais que compõem o produto, como exemplificado na Figura A.5.3. A etapa final é a formação dos BSC com as cores vermelha, amarela e verde de acordo com os níveis estipulados na primeira etapa (Figura A.5.1). Um exemplo de BSC é apresentado na Figura A.5.4.

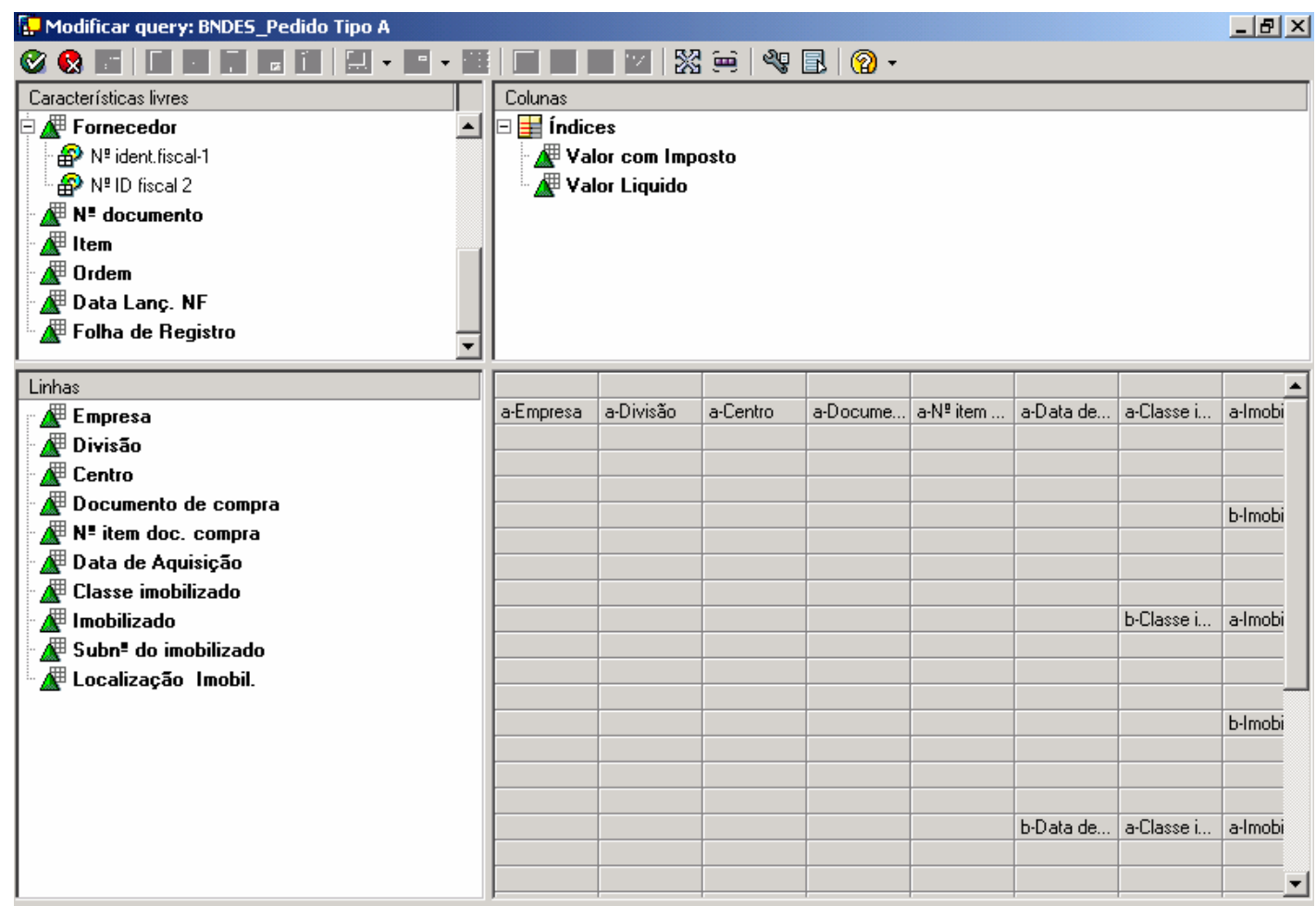

Figura A.5.1: Primeiro passo para a formação do BSC - a definição dos dados do sistema que serão extraídos de acordo com os indicadores selecionados.

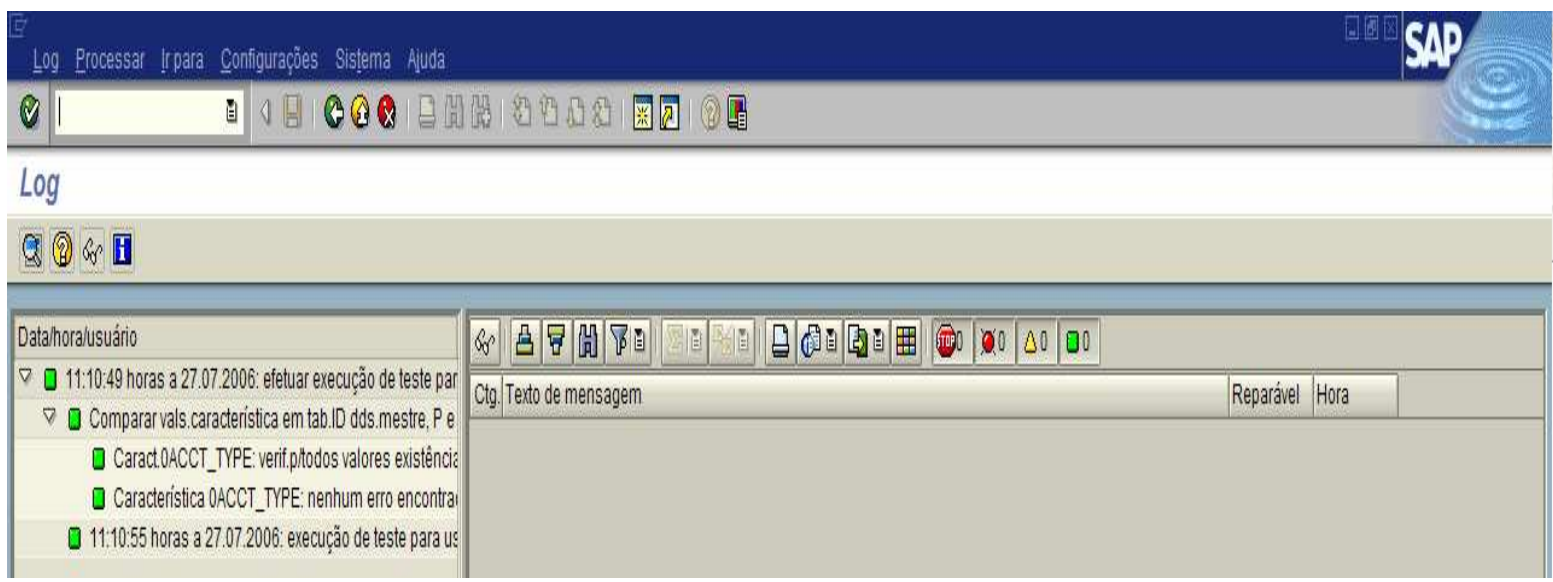


Figura A.5.2: níveis dos indicadores são configurados, de acordo com as metas estipuladas

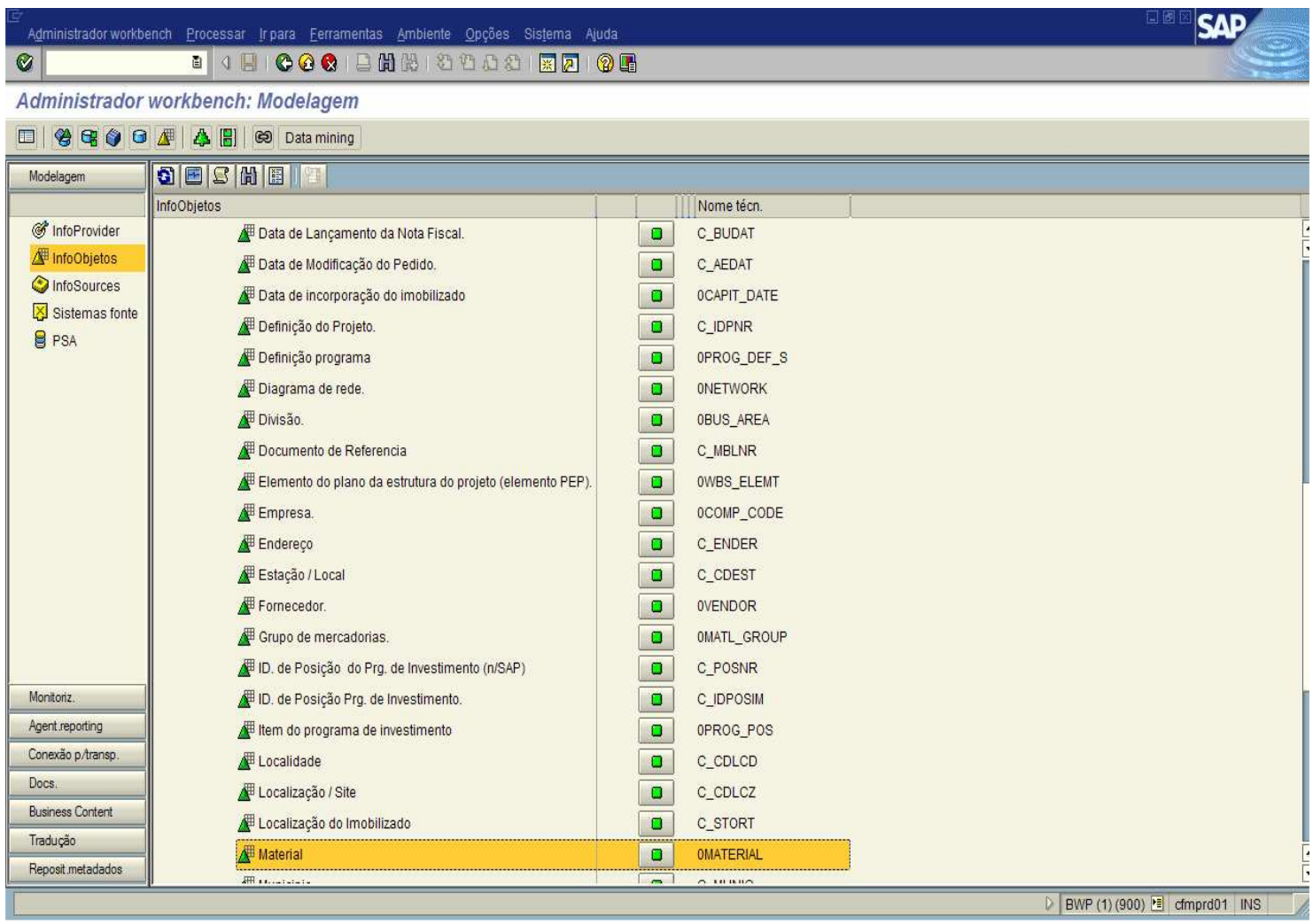

Figura A.5.3: Extração dos indicadores dos dados mestres do sistema, neste exemplo materiais que compõem o produto. 


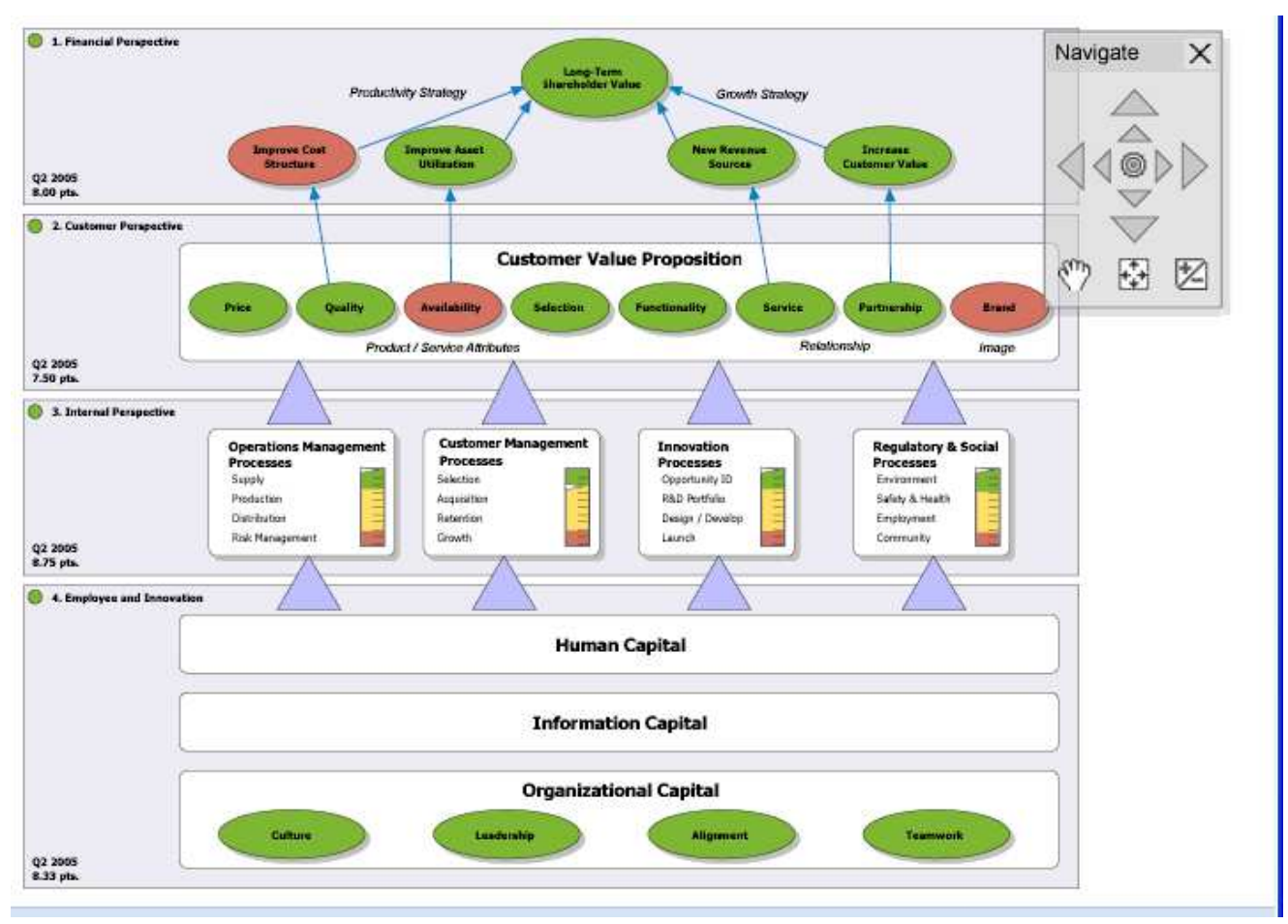

Figura A.5.4 Formação do BSC- as cores vermelha, amarela e verde estão de acordo com os níveis estipulados na Figura A.5.1.

O BSC, obtido através do software como demonstrou a seqüência de figuras, apresenta os três pilares da sustentabilidade: ambiente - sociedade - economia. Assim, o BSC configurado é formado por indicadores parciais (os dados do sistema referentes às questões ambientais, econômica e social) que permitem a rastreabilidade e localização de pontos falhos, para que os indicadores globais da sustentabilidade sejam obtidos com maior precisão.

\section{ANEXO 6 INDICADORES AMBIENTAIS DA FUNDAÇÃO VANZOLINI}

\section{Este Anexo é descrito como encontrado em}

http://www.jornaldomeioambiente.com.br/GestaoAmbiental/FundacaoVanzolini.asp, acessado em janeiro/2007.

Fontes de recursos - extração

i. Há reposição de estoques naturais

ii. Garante a viabilidade do ecossistema

iii. Há eficiência e eficácia no consumo de água e energia

\footnotetext{
Matérias primas ou eco-materiais

i. São naturais e renováveis

ii. São simples ou, se mistos são separáveis e recicláveis

iv. O reprocessamento é atóxico, água e energia-eficiente
} 
v. São recicláveis de maneira atóxica, água e energia-efetivos

vi. São leves e utilizados em pequenos volumes

\section{Processo de produção}

i. É atóxico

ii. Não gera subprodutos e resíduos tóxicos e perigosos

iii. Há fechamento de ciclos (loopings) e reuso de materiais

iv. Há reciclagem primária atóxica, água e energia-eficiente

v. É água e energia efetivos

\section{Produto}

i. É atóxico

ii. Tem maior vida útil que o similar

iii. É fácil de desmontar, remontar e consertar

iv. É adaptável (fitness, function, fashion)

v. É modulável e atualizável (upgradable)

vi.É remanufaturável

vii. É elaborado com resíduo ou material reciclado

viii. Funciona com baixo consumo de água e energia

ix. Usa o mínimo de embalagem

x. A embalagem é reciclável (atóxica, água e energia eficientes)

\section{Tecnologia limpa}

i. Resíduo zero ou mínimo possível

ii. Entradas e saídas mínimas de materiais tóxicos

iii. Utiliza energia limpa

iv. Reciclagem atóxica, água e energia eficientes

v. Adota o princípio da precaução

vi. Adota o princípio da prevenção

vii. Adota a visão holística ou Life Cycle Assessment

viii. Pratica o controle democrático da tecnologia

ix. Analisa o fluxo upstream e downstream do produto e processo

$\mathrm{x}$. Analisa o fluxo upstream do consumo do produto e emblagens

xi. Analisa o fluxo upstream de resíduos e subprodutos

xii. Há projeto executivo, com cronogramas e metas objetivas

\section{Marketing ambiental}

i.Pratica o leasing de função, de desempenho e de serviços

ii. Pratica o uso compartilhado de produtos, processos e serviços

iii. O produto é gerador de mercado de segunda mão

iv. Promove a pós-utilização de produtos e materiais

v. Há devolução garantida de produtos e embalagens (take back)

vi. Há Extended Producer Responsibility -

vii. Pratica o direito de acesso público à informação

\section{Manejo ambiental}

i. Pratica a prevenção de resíduos na fonte de produção

ii. Faz reclagem primária (on site)

iii. Faz reciclagem secundária (off site)

iv. Não faz despejo em aterros

v. Não usa a incineraçao

vi. Adota padrões elevados de saúde e segurança no trabalho

\section{Conformidade ambiental}

i. Atende a Legislação nacional e local

ii. Não importa lixo tóxico

iii. Não utiliza POPs (poluentes orgânicos persistentes)

iv. Não provoca poluição transfronteiriça

v. Não contribui para aquecimento do planeta

vi. Não provoca destruição da camada de ozônio 
vii. Não causa poluição marinha e de estuários

viii. Não comerlcializa espécies em extinção

ix. Não prejudica zonas úmidas de importância internacional

$\mathrm{x}$. Não prejudica a biodiversidade

Comunicação ambiental

Divulga sua política e práticas ambientais através de

Estágio 1 - folhetos e notícias verdes, vídeos e pequenas declarações no Relatório anual da empresa

Estágio 2 - publicação específica de Relatório Ambiental, correlacionado `a definição de política ambiental da empresa

Estágio 3 - relatório anual, integrado ao sistema de manejo ambiental, porém, com mais texto do que figuras

Estágio 4 - relatório anual detalhado de emissões de resíduos, informações disponíveis on-line e em disquetes.

Relatório Ambiental incluído no Relatório de Negócios anual da empresa.

ANEXO 7 INDICADORES DO BALANÇO SOCIAL EXIGIDOS PELO IBES

A Figura A.7.1 mostra a proposta de indicadores de balanço social de acordo com o IBES e indica o módulo do SAP onde cada um pode ser encontrado. 


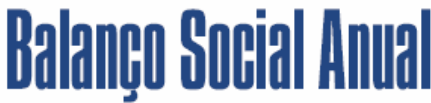

1. Base de cálculo

Receita líquida (RL)

Resultado operacional (RO)

Folha de pagamento bruta (FPB)

2. Indicadores sociais internos Alimentação

Encargos sociais compulsórios

Previdência privada

Saúde

Segurança e medicina no trabalho

Educação

Cultura

Capacitação e desenvolvimento profissional

Creches ou auxílio-creche

Participação nos lucros ou resultados

Outros

Total - Indicadores sociais internos

3. Indicadores sociais externos

Educação

Cultura

Saúde e saneamento

Esporte

Combate à fome e segurança alimentar

\section{Outros}

Total das contribuições para a sociedade

Tributos (excluídos encargos sociais)

Total - Indicadores sociais externos

4. Indicadores ambientais

Investimentos relacionados com a produção/operação da empresa

Investimentos em programas e/ou projetos externos

Total dos investimentos em meio ambiente

Quanto ao estabelecimento de metas anuais para minimizar

resíduos, o consumo em geral na produção/operação e aumentar

a eficácia na utilização de recursos naturais, a empresa:

5. Indicadores do corpo funcional

$\mathrm{N}^{\circ}$ de empregados(as) ao final do período

$\mathrm{N}^{\circ}$ de admissões durante o período

$\mathrm{N}^{\circ}$ de empregados(as) terceirizados(as)

$\mathrm{N}^{\circ}$ de estagiários(as)

$\mathrm{N}^{\circ}$ de empregados(as) acima de 45 anos

$\mathrm{N}^{\circ}$ de mulheres que trabalham na empresa

$\%$ de cargos de chefia ocupados por mulheres

$\mathrm{N}^{\circ}$ de negros(as) que trabalham na empresa

$\%$ de cargos de chefia ocupados por negros(as)

$\mathrm{N}^{\circ}$ de portadores(as) de deficiência ou necessidades especiais

6. Informaçōes relevantes quanto ao

exercício da cidadania empresarial

Relação entre a maior e a menor remuneração na empresa

Número total de acidentes de trabalho

Relatórios a serem extraídos do módulo do SAP R/3 denomidano Financial Account

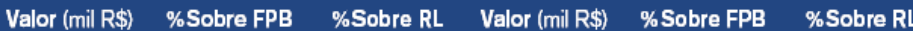

Retórios a serem extraídos do módulo denominado Human Resources, no SAP R/3
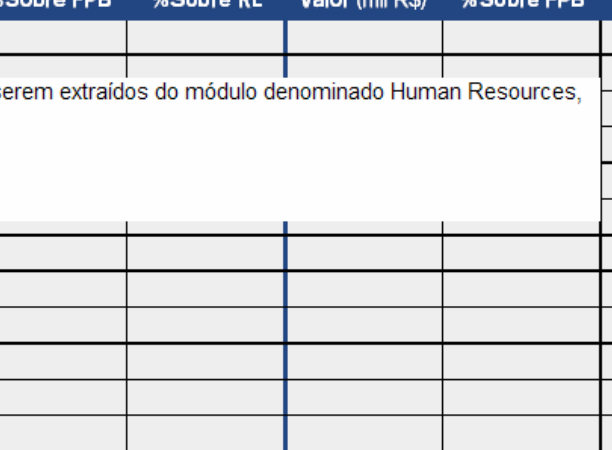

Valor (mil R\$) \%Sobre RO $\quad$ \%Sobre RL Valor (mil R\$) \%Sobre RO \%Sobre RL

Relatórios a serem extraidos do módulo denominado Human Resources no SAP $\mathrm{R} / 3$ 
4 ANEXO 8 QUESTIONÁRIO ENVIADO AOS ASSOCIADOS DA ABRACI

ता

aㅐ알त

\begin{tabular}{|c|c|c|c|c|c|c|c|}
\hline \multirow[t]{2}{*}{ Resíduos Sólidos } & \multirow[t]{2}{*}{$\begin{array}{l}\text { Nome da empresa } \\
\text { Processador do Resíduo }\end{array}$} & \multirow[t]{2}{*}{$\begin{array}{c}\text { Prazo - Atribuir notas }(0,1 \text { e } 2) \text { para o nível } \\
\text { de atendimento }{ }^{1} \text { - prazo }\end{array}$} & \multicolumn{2}{|c|}{$\begin{array}{c}\text { O resíduo é } \\
\text { vendido pela } \\
\text { empresa } \\
\text { geradora }\end{array}$} & \multicolumn{2}{|c|}{$\begin{array}{l}\text { O resíduo é } \\
\text { pago pela } \\
\text { empresa } \\
\text { geradora }\end{array}$} & \multirow[t]{2}{*}{$\begin{array}{l}\text { Custo dc } \\
\text { (custo el }\end{array}$} \\
\hline & & & $\mathrm{S} / \mathrm{N}$ & $\begin{array}{l}\text { Custo em } \\
R \$\end{array}$ & $\mathrm{~S} / \mathrm{N}$ & $\begin{array}{l}\text { Custo em } \\
R \$\end{array}$ & \\
\hline \multicolumn{8}{|l|}{ Metais Ferrosos e não Ferrosos } \\
\hline \multicolumn{8}{|l|}{ Sucata de Metais Não Ferrosos } \\
\hline \multicolumn{8}{|l|}{ Papel, Papelão, Plástico, Madeira } \\
\hline \multicolumn{8}{|l|}{ Lixo de Restaurante } \\
\hline \multicolumn{8}{|l|}{ Com Fenol } \\
\hline \multicolumn{8}{|l|}{ de Varrição de Fábrica } \\
\hline \multicolumn{8}{|c|}{ Torta de Filtro Prensa - Lodo Galvânico da ETE } \\
\hline \multicolumn{8}{|l|}{ Embalagens contaminadas } \\
\hline Outros - especificar & & & & & & & \\
\hline
\end{tabular}

5 Pesquisa sobre Relacionamento com os Processadores de Resíd 


\begin{tabular}{|c|c|c|c|c|c|c|c|}
\hline \multirow[t]{2}{*}{ Resíduos Líquidos } & \multirow[t]{2}{*}{$\begin{array}{l}\text { Nome da empresa } \\
\text { Processador do Resíduo }\end{array}$} & \multirow[t]{2}{*}{$\begin{array}{c}\text { Prazo - Atribuir notas }(0,1 \text { e } 2) \text { para o nível } \\
\text { de atendimento }{ }^{1} \text { - prazo }\end{array}$} & \multicolumn{2}{|c|}{$\begin{array}{c}\text { O resíduo é } \\
\text { vendido pela } \\
\text { empresa } \\
\text { geradora }\end{array}$} & \multicolumn{2}{|c|}{$\begin{array}{l}\text { O resíduo é } \\
\text { pago pela } \\
\text { empresa } \\
\text { geradora }\end{array}$} & \multirow[t]{2}{*}{$\begin{array}{l}\text { Custo dc } \\
\text { (custo el }\end{array}$} \\
\hline & & & $\mathrm{S} / \mathrm{N}$ & $\begin{array}{c}\text { Custo em } \\
\mathrm{R} \$\end{array}$ & $\mathrm{~S} / \mathrm{N}$ & $\begin{array}{c}\text { Custo em } \\
\mathrm{R} \$\end{array}$ & \\
\hline \multicolumn{8}{|l|}{ Com Solventes } \\
\hline \multicolumn{8}{|l|}{ Efluentes Com Metais Pesados exceto cobre } \\
\hline \multicolumn{8}{|l|}{ Efluentes com Cobre } \\
\hline \multicolumn{8}{|l|}{ Efluentes Domésticos } \\
\hline \multicolumn{8}{|l|}{ Efluentes Ácidos } \\
\hline \multicolumn{8}{|l|}{ Efluentes Alcalino } \\
\hline \multicolumn{8}{|l|}{ Efluentes Orgânicos $\left({ }^{\star}\right)$} \\
\hline \multicolumn{8}{|l|}{ Lodo de fossa séptica } \\
\hline \multicolumn{8}{|l|}{ Solventes } \\
\hline \multicolumn{8}{|l|}{ Outros - especificar } \\
\hline \multirow{2}{*}{$\begin{array}{l}\text { Produto não conforme (especificar } \\
\text { brevemente o produto) }{ }^{\star}\end{array}$} & \multirow[t]{2}{*}{ Processamento do produto } & \multirow[t]{2}{*}{ Prazo para processamento } & \multicolumn{2}{|c|}{$\begin{array}{l}\text { O produto é } \\
\text { reciclado na } \\
\text { empresa }\end{array}$} & \multicolumn{2}{|c|}{$\begin{array}{l}\text { O produto é } \\
\text { reciclado em } \\
\text { outra empresa }\end{array}$} & \multirow{2}{*}{$\begin{array}{r}\text { Custo da reci } \\
\text { descarte }\end{array}$} \\
\hline & & & $\mathrm{S} / \mathrm{N}$ & Como & $\mathrm{S} / \mathrm{N}$ & Como & \\
\hline
\end{tabular}

Instruções: Nível de Atendimento1 (Prazo): 1- Satisfatório, 2 - Insatisfatório (entre 1 e 3 dias de atraso); 3 - Insatisfatório Grave (mais que 3 dias de atraso) Licenças Ambientais ${ }^{2}$ : Informar se o processador tem Licenças Ambientais: (Instalação/Funcionamento/CADRI), S/N (sim ou não).

Certificação ${ }^{3}$ : Informar se o processador está Certificado: (ISO14.000/18.000, ISO 9001/2 ou ISO TS ). S/N Sim ou Não.

* Corresponde a qualquer produto descartado na empresa e que não foi computado nas linhas anteriores 
